medRxiv preprint doi: https://doi.org/10.1101/2020.03.19.20039008; this version posted March 25, 2020. The copyright holder for this preprint (which was not certified by peer review) is the author/funder, who has granted medRxiv a license to display the preprint in perpetuity. It is made available under a CC-BY-NC-ND 4.0 International license .

\title{
Effectiveness and safety of antiviral or antibody treatments for coronavirus
}

(L) STIMICHCHAE'S

A rapid review

Prepared for Public Health Agency of Canada

Submitted 2/25/2020

\section{Prepared By:}

Knowledge Translation Program Li Ka Shing Knowledge Institute

St. Michael's Hospital

\section{Contact:}

Dr. Andrea Tricco

E: Andrea.Tricco@unityhealth.to

T: 416-864-6060 ext.77521 
medRxiv preprint doi: https://doi.org/10.1101/2020.03.19.20039008; this version posted March 25, 2020. The copyright holder for this preprint (which was not certified by peer review) is the author/funder, who has granted medRxiv a license to display the preprint in perpetuity.

It is made available under a CC-BY-NC-ND 4.0 International license .

Contributors: Patricia Rios, Amruta Radhakrishnan, Jesmin Antony, Sonia Thomas, Matthew Muller, Sharon E. Straus, Andrea C. Tricco.

Acknowledgements: Jessie McGowan (literature search), Tamara Rader (literature search), Krystle Amog (report preparation), Chantal Williams (report preparation), Naveeta Ramkissoon (report preparation)

\section{Copyright claims/Disclaimers}

The intellectual property rights in data and results generated from the work reported in this document are held in joint ownership between the MAGIC team and the named Contributors.

Users are permitted to disseminate the data and results presented in this report provided that the dissemination (i) does not misrepresent the data, results, analyses or conclusions, and (ii) is consistent with academic practice, the rights of any third party publisher, and applicable laws. Any dissemination of the data and results from this document shall properly acknowledge the MAGIC team and named Contributors.

\section{Funding Statement:}

This work was supported through the Drug Safety and Effectiveness Network funded by the Canadian Institutes of Health Research.

For questions about this report, please contact:

Andrea Tricco, MSc, PhD

NPI, MAGIC Team, Drug Safety and Effectiveness Network, Canadian Institutes of Health

Research

Director, Knowledge Synthesis Team

Knowledge Translation Program

Li Ka Shing Knowledge Institute

St. Michael's Hospital

Toronto, Canada

Email: Andrea.Tricco@unityhealth.to

Phone: 416-864-6060 ext. 77521 
medRxiv preprint doi: https://doi.org/10.1101/2020.03.19.20039008; this version posted March 25, 2020. The copyright holder for this preprint (which was not certified by peer review) is the author/funder, who has granted medRxiv a license to display the preprint in perpetuity.

It is made available under a CC-BY-NC-ND4.0 International license .
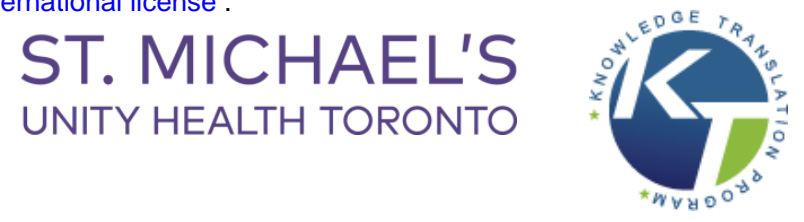

\section{ABSTRACT}

Background: To identify safe and effective medical countermeasures (e.g., antivirals/antibodies) to address the current outbreak of a novel coronavirus (COVID-19)

Methods: Comprehensive literature searches were developed by an experienced librarian for MEDLINE, EMBASE, the Cochrane Library, and biorxiv.org/medrxiv.org; additional searches for ongoing trials and unpublished studies were conducted in clinicaltrials.gov and the Global Infectious Diseases and Epidemiology Network (GIDEON). Title/abstract and full-text screening, data abstraction, and risk of bias appraisal were carried out by single reviewers.

Results: 54 studies were included in the review: three controlled trials, 10 cohort studies, seven retrospective medical record/database studies, and 34 case reports or series. These studies included patients with severe acute respiratory syndrome (SARs, $n=33$ ), middle east respiratory syndrome (MERS, $n=16)$, COVID-19 $(n=3)$, and unspecified coronavirus $(n=2)$. The most common treatment was ribavirin $(n=41)$, followed by oseltamivir $(n=10)$ and the combination of lopinavir/ritonavir $(n=7)$. Additional therapies included broad spectrum antibiotics $(n=30)$, steroids $(n=39)$ or various interferons $(n=12)$. No eligible studies examining monoclonal antibodies for COVID-19 were identified. One trial found that ribavirin prophylactic treatment statistically significantly reduced risk of MERS infection in people who had been exposed to the virus. Of the 21 studies reporting rates of ICU admission in hospitalized SARS or MERS patients, none reported statistically significant results in favour of or against antiviral therapies. Of the 40 studies reporting mortality rates in hospitalized SARS or MERS patients, one cohort study (MERS) and one retrospective study (SARS) found a statistically significant increase in the mortality rate for patients treated with ribavirin. Eighteen studies reported potential drugrelated adverse effects including gastrointestinal symptoms, anemia, and altered liver function in patients receiving ribavirin.

Conclusion: The current evidence for the effectiveness and safety of antiviral therapies for coronavirus is inconclusive and suffers from a lack of well-designed prospective trials or observational studies, preventing any treatment recommendations from being made. However, it is clear that the existing body of evidence is weighted heavily towards ribavirin (41/54 studies), which has not shown conclusive evidence of effectiveness and may cause harmful adverse events so future investigations may consider focusing on other candidates for antiviral therapy. 
medRxiv preprint doi: https://doi.org/10.1101/2020.03.19.20039008; this version posted March 25, 2020. The copyright holder for this preprint (which was not certified by peer review) is the author/funder, who has granted medRxiv a license to display the preprint in perpetuity. It is made available under a CC-BY-NC-ND 4.0 International license .

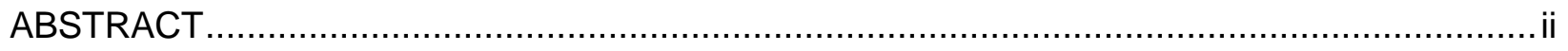

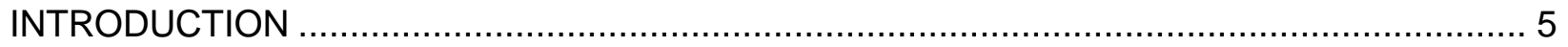

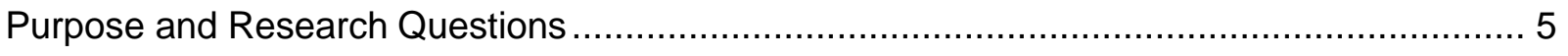

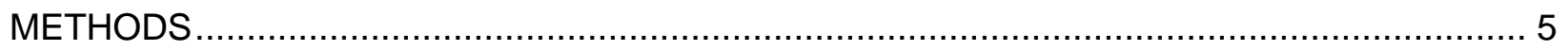

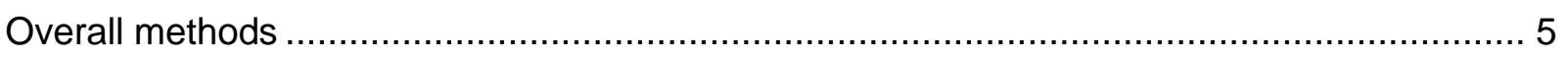

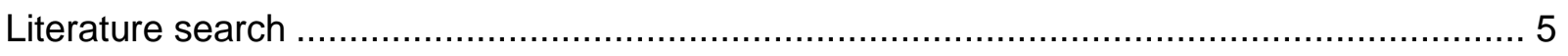

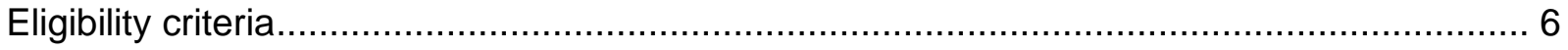

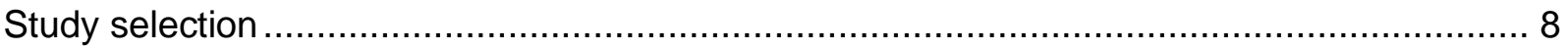

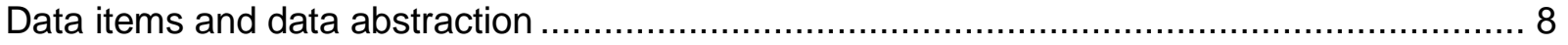

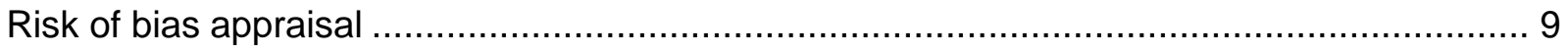

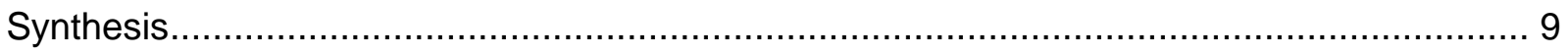

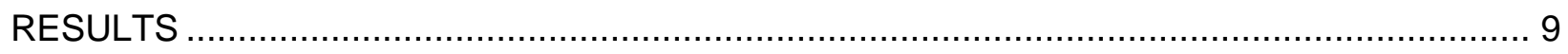

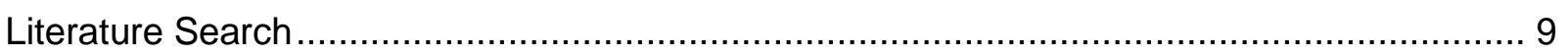

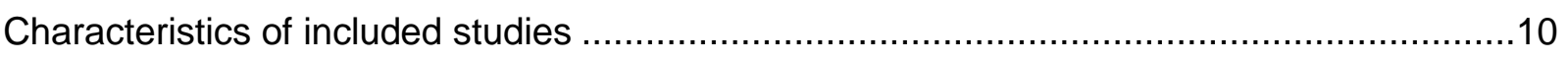

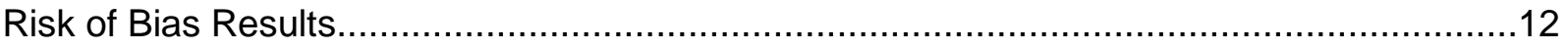

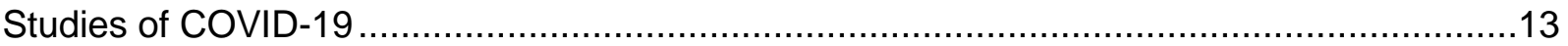

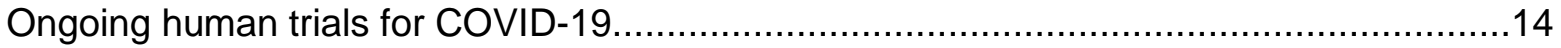

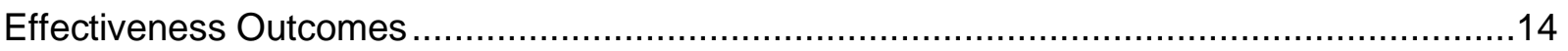

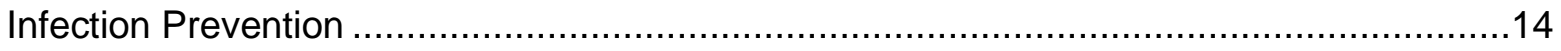

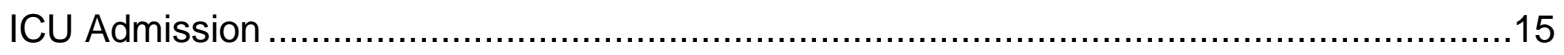

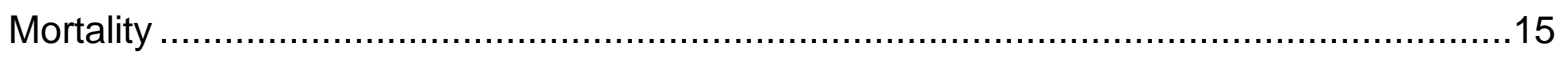

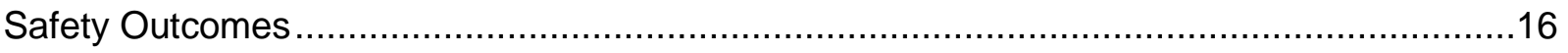

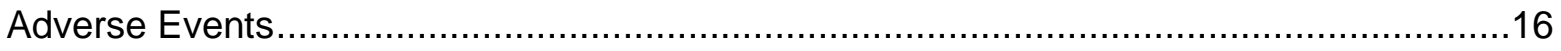

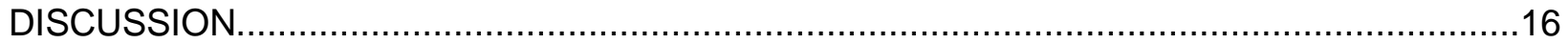

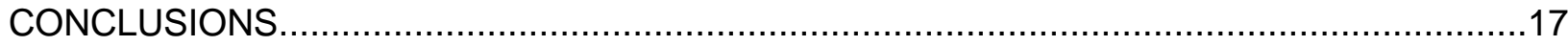

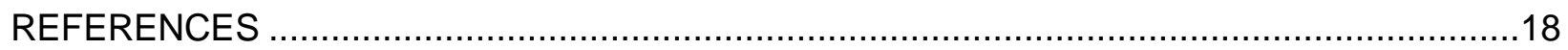

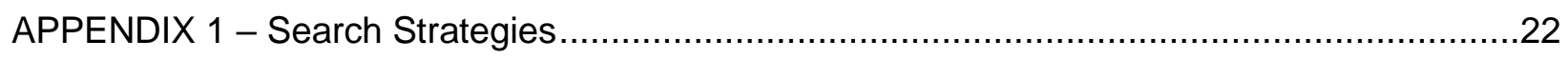

APPENDIX 2 - Potentially relevant articles not included in this review ...............................24

APPENDIX 3 - Detailed Table of Study and Patient Characteristics ....................................32 
medRxiv preprint doi: https://doi.org/10.1101/2020.03.19.20039008; this version posted March 25, 2020. The copyright holder for this preprint (which was not certified by peer review) is the author/funder, who has granted medRxiv a license to display the preprint in perpetuity.

It is made available under a CC-BY-NC-ND 4.0 International license .

APPENDIX 4 - Detailed Table of Interventions and Outcomes ..........................................40

APPENDIX 5 - Quality Appraisal/Risk of Bias - Complete Results ...................................61 
medRxiv preprint doi: https://doi.org/10.1101/2020.03.19.20039008; this version posted March 25, 2020. The copyright holder for this preprint (which was not certified by peer review) is the author/funder, who has granted medRxiv a license to display the preprint in perpetuity.

It is made available under a CC-BY-NC-ND4.0 International license .

\section{INTRODUCTION}

\section{Purpose and Research Questions}

The Infectious Disease Prevention and Control Branch of the Public Health Agency of Canada (PHAC) submitted a query on the effectiveness and safety of antiviral, antibody, or other medical countermeasures for the treatment of novel coronavirus (COVID-19) through the Canadian Institutes of Health Research (CIHR) Drug Safety and Effectiveness Network (DSEN). They requested the DSEN Methods and Application Group in Indirect Comparisons (MAGIC) Team conduct a rapid review on this topic with an approximate 2-week timeline.

The overall objective of this rapid review was to identify safe and effective medical countermeasures to address the current outbreak of a novel coronavirus (COVID-19). In order to focus the research question to increase feasibility, we proposed the following key research questions:

1. What is the effectiveness and safety of any antiviral and/or monoclonal antibody treatment currently available to treat (COVID-19)?

2. What is the effectiveness and safety of currently available antiviral therapies used to treat other coronavirus infections?

\section{METHODS}

\section{Overall methods}

The rapid review conduct was guided by the Cochrane Handbook for Systematic Reviews of Interventions ${ }^{1}$ along with the Rapid Review Guide for Health Policy and Systems Research ${ }^{2}$. The team used an integrated knowledge translation approach, with consultation from the knowledge users from the Public Health Agency of Canada at the following stages: question development, literature search, study inclusion, interpretation of results, and draft report. After the report is submitted to the Public Health Agency of Canada, a manuscript will be prepared for publication and we will invite our knowledge users to join us as coauthors. We will use the Preferred Reporting Items for Systematic Reviews and Meta-Analyses (PRISMA) Statement ${ }^{3}$ to guide the reporting of our rapid review results; a PRISMA extension specific to rapid reviews is currently under development.

\section{Literature search}

Comprehensive literature searches addressing both research question 1 (RQ1) and research question 2 (RQ2) were developed by an experienced librarian for MEDLINE, EMBASE, the Cochrane Library, and biorxiv.org/medrxiv.org databases. Grey (i.e., difficult to locate or unpublished) literature was located using keyword searches of relevant terms (e.g. coronavirus, SARS, etc.) in clinicaltrials.gov and GIDEON (Global Infectious Diseases and Epidemiology Network). Additionally, the final set of included articles was cross-referenced with a list studies provided by our knowledge users from the Public Health Agency of Health as part of the scoping process for this review. The full MEDLINE search strategy and grey literature search keywords can be found in Appendix 1. 
medRxiv preprint doi: https://doi.org/10.1101/2020.03.19.20039008; this version posted March 25, 2020. The copyright holder for this preprint (which was not certified by peer review) is the author/funder, who has granted medRxiv a license to display the preprint in perpetuity.

It is made available under a CC-BY-NC-ND 4.0 International license.

\section{Eligibility criteria}

The Eligibility criteria followed the PICOST framework and consisted of:

Population (for research question 1 (RQ1) and 2 (RQ2): Individuals of any age treated for a coronavirus infection. Subgroups of interest include older adults aged $>65$ years, pediatric, pregnant, or immunocompromised patients.

\section{Intervention:}

- $\quad$ The following interventions were eligible for RQ1:

- Antiviral medications approved for use in COVID-19 or currently in pre-clinical trials (animal studies, excluding in vitro studies) for treating COVID-19 (see Table 1).

- Monoclonal antibodies approved for use in COVID-19 or currently in pre-clinical trials (animal studies, excluding in vitro studies) for treating COVID-19.

- The following interventions were of interest for RQ2:

- Antiviral agents used alone or in combination that are approved for use in coronavirus treatment or are being examined in clinical trials for use in coronavirus treatment (Table 1).

Comparator (for RQ1 and RQ2): One of the interventions listed above, no intervention, or placebo.

Outcomes (for RQ1 and RQ2): lab-confirmed coronavirus infection, hospitalization, intensive care unit (ICU) admission, mortality, and adverse events (e.g., exacerbation of infection).

Table 1: Example list of relevant interventions*

\begin{tabular}{|c|c|c|}
\hline $\begin{array}{l}\text { Treatment } \\
\text { indication/Drug } \\
\text { class }\end{array}$ & List of medications & \\
\hline $\begin{array}{l}\text { Experimental } \\
\text { antiviral agents }\end{array}$ & - $\quad$ Remdesivir (GS-5734) & \\
\hline $\begin{array}{l}\text { Influenza virus } \\
\text { infections }\end{array}$ & $\begin{array}{ll}\text { - } & \text { ribavirin (Ibavyr) } \\
\text { - } & \text { matrix } 2 \text { protein inhibitors } \\
\circ \text { amantadine } \\
\text { - } & \text { RNA polymerase inhibitors } \\
& 0 \text { rimantadine }\end{array}$ & $\begin{array}{cc}\text { - } & \text { neuraminidase inhibitors } \\
\circ & \text { oseltamivir (Tamiflu) } \\
\circ & \text { peramivir (Rapivab) } \\
\circ & \text { zanamivir (Relenza) }\end{array}$ \\
\hline $\begin{array}{l}\text { Human } \\
\text { cytomegalovirus } \\
\text { infections }\end{array}$ & $\begin{array}{l}\text { - acyclic guanosine analogues } \\
\circ \text { acyclovir } \\
\text { - acyclic nucleoside phosphonate } \\
\text { analogues } \\
\circ \text { cidofovir } \\
\circ \text { diphosphates }\end{array}$ & $\begin{array}{l}\text { - } \text { pyrophosphate analogues } \\
\circ \text { foscarnet } \\
\circ \text { fomivirsen } \\
\text { - oligonucleotides }\end{array}$ \\
\hline
\end{tabular}


medRxiv preprint doi: https://doi.org/10.1101/2020.03.19.20039008; this version posted March 25, 2020. The copyright holder for this preprint (which was not certified by peer review) is the author/funder, who has granted medRxiv a license to display the preprint in perpetuity.

It is made available under a CC-BY-NC-ND 4.0 International license.

\begin{tabular}{|c|c|c|}
\hline $\begin{array}{l}\text { Treatment } \\
\text { indication/Drug } \\
\text { class }\end{array}$ & List of medications & \\
\hline $\begin{array}{l}\text { Respiratory } \\
\text { syncytial virus } \\
\text { infections }\end{array}$ & - ribavirin (lbavyr) and antibodies & \\
\hline HIV infections & $\begin{array}{cl}\text { - } & \text { protease inhibitors } \\
\circ & \text { boceprevir } \\
0 & \text { telaprevir } \\
0 & \text { lopinavir } \\
0 & \text { ritonavir } \\
0 & \text { darunavir/cobicistat } \\
& \text { (Prezcobix) } \\
\circ & \text { indinavir (Crixivan) } \\
\circ & \text { saquinavir (Invirase) } \\
\text { - integrase inhibitors } \\
\circ \text { raltegravir } \\
\circ \text { elvitegravir } \\
\circ \text { dolutegravir } \\
\text { entry (fusion) inhibitors } \\
\circ \text { maraviroc } \\
\circ \text { celsentri } \\
\text { nucleoside reverse transcriptase } \\
\text { inhibitors } \\
\circ \text { abacavir } \\
\circ \text { ziagen } \\
\circ \text { emtricitabine } \\
\circ \text { emtriva } \\
\circ \text { lamivudine } \\
\end{array}$ & $\begin{array}{cl} & \text { epivir } \\
\circ & \text { tenofovir } \\
\circ & \text { viread } \\
\circ & \text { zidovudine } \\
\circ & \text { azidothymidine } \\
\circ & \text { retrovir } \\
\text { - } \quad \text { nonnucleoside reverse } \\
\text { transcriptase inhibitors } \\
\circ \text { doravirine } \\
\circ \text { pifeltro } \\
\circ \text { efavirenz } \\
\circ \text { sustiva } \\
\circ \text { etravirine } \\
\circ \text { intelence } \\
\circ \text { nevirapine } \\
\circ \text { viramune } \\
\circ \text { rilpivirine } \\
\circ \text { edurant } \\
\text { acyclic nucleoside } \\
\text { phosphonate analogues } \\
\circ \text { cidofovir } \\
\circ \text { diphosphates } \\
\end{array}$ \\
\hline $\begin{array}{l}\text { Immune } \\
\text { modulators }\end{array}$ & - interferon $1 \beta$ (Betaseron/Extavia) & \\
\hline $\begin{array}{l}\text { Monoclonal } \\
\text { Antibodies }\end{array}$ & $\begin{array}{ll}\text { - } & \text { abciximab (Reopro) } \\
\text { - } & \text { adalimumab (Humira/Amjevita) } \\
\text { - } & \text { alefacept (Amevive) } \\
\text { - } & \text { basiliximab (Simulect) } \\
\text { - } & \text { belimumab (Benlysta) } \\
\text { - } & \text { bezlotoxumab (Zinplava) } \\
\text { - } & \text { canakinumab (Ilaris) } \\
\text { - } & \text { certolizumab (Cimzia) } \\
\text { - } & \text { cetuximab (Erbitux) } \\
\text { - } & \text { daclizumab (Zenapax/Zinbryta) } \\
\text { - } & \text { denosumab (Prolia/Xgeva) } \\
\text { - } & \text { efalizumab (Raptiva) } \\
\text { - } & \text { golimumab (Simponi) } \\
\text { - } & \text { inflectra (Remicade) }\end{array}$ & $\begin{array}{ll}\text { - } & \text { ipilimumab (Yervoy) } \\
\text { - } & \text { ixekizumab (Taltz) } \\
\text { - } & \text { natalizumab (Tysabri) } \\
\text { - } & \text { nivolumab (Opdivo) } \\
\text { - } & \text { olaratumab (Lartruvo) } \\
\text { - } & \text { omalizumab (Xolair) } \\
\text { - } & \text { palivizumab (Synagis) } \\
\text { - } & \text { panitumumab (Vectibix) } \\
\text { - } & \text { pembrolizumab (Keytruda) } \\
\text { - } & \text { rituximab (Rituxan) } \\
\text { - } & \text { tocilizumab (Actemra) } \\
\text { - } & \text { trastuzumab (Herceptin) } \\
\text { - } & \text { secukinumab (Cosentyx) } \\
\text { - } & \text { ustekinumab (Stelara) }\end{array}$ \\
\hline
\end{tabular}

${ }^{*}$ Note: not an exhaustive list 
medRxiv preprint doi: https://doi.org/10.1101/2020.03.19.20039008; this version posted March 25, 2020. The copyright holder for this preprint (which was not certified by peer review) is the author/funder, who has granted medRxiv a license to display the preprint in perpetuity.

It is made available under a CC-BY-NC-ND4.0 International license.

Study designs:

- The following study designs were eligible for RQ1:

- Randomized controlled trials (RCTs) and quasi-RCTs

- Non-randomized studies (e.g., non-randomized trials, interrupted time series, controlled before after)

- Observational studies (e.g., cohort, case control, cross-sectional)

- Case studies, case reports, and case series

- Pre-clinical (animal) studies

- The following study designs were eligible for RQ2:

- Randomized controlled trials (RCTs) and quasi-RCTs

- Non-randomized studies (e.g., quasi-RCTs, non-randomized trials, interrupted time series, controlled before after)

- Observational studies (e.g., cohort, case control, cross-sectional)

Time periods (for RQ1 and RQ2): All periods of time and duration of follow-up were eligible.

Other (for RQ1 and RQ2): Only studies published in English were eligible for inclusion, due to the short timelines for this review. Relevant studies written in languages other than English and relevant studies of an ineligible design (e.g., trial protocol, literature review) will be excluded but reported in an appendix of possibly relevant articles (Appendix 2).

\section{Study selection}

For both level 1 (title/abstract) and level 2 (full-text) screening, a screening form was prepared based on the eligibility criteria and pilot-tested by the review team using 25 citations prior to level 1 screening and 10 full text articles prior to level 2 screening. Agreement between reviewers was sufficiently high $(>75 \%)$ in both cases so no further pilot-testing was required. Full screening was completed by a single reviewer for both level 1 and level 2 using Synthesi.SR, the team's proprietary online software [https://breakthroughkt.ca/login.php].

\section{Data items and data abstraction}

Items for data abstraction included study characteristics (e.g., study period, study design, country of conduct), patient characteristics (e.g., mean age, age range, co-morbidities), intervention details (e.g., type of intervention, dose, timing of treatment), comparator details (e.g., comparator intervention, dose), and outcome results (e.g., hospitalizations due to coronavirus, adverse events, mortality) at the longest duration of follow-up.

A standardized data abstraction form was developed to capture data on the above listed items. Prior to data abstraction, a calibration exercise was completed to test the form amongst the entire review team using two randomly selected full-text articles. Following successful completion of the calibration exercise, included studies were abstracted by single reviewers. 
medRxiv preprint doi: https://doi.org/10.1101/2020.03.19.20039008; this version posted March 25, 2020. The copyright holder for this preprint (which was not certified by peer review) is the author/funder, who has granted medRxiv a license to display the preprint in perpetuity.

It is made available under a CC-BY-NC-ND 4.0 International license .

\section{Risk of bias appraisal}

Risk of bias appraisal was carried out by single reviewers using Cochrane Risk of Bias (RoB) tool $^{4}$ for controlled trials and the Newcastle Ottawa Scale ${ }^{5}$ (NOS) for cohort or case-control studies.

\section{Synthesis}

Included studies were synthesized descriptively including summary statistics and detailed tables of study characteristics and results. Tables of study results are organized according to study design and where available, information on relevant subgroups were highlighted.

\section{RESULTS}

\section{Literature Search}

The database search returned a total of 4,491 citations, while the grey literature searches returned 305 citations, and 8 additional citations were identified from the articles provided by our knowledge users from the Public Health Agency of Canada for level 1 screening. A total of 4,567 citations were excluded after level 1 screening and a further 81 citations were identified as ineligible for the current review but potentially of interest to knowledge users, leaving 156 potentially relevant articles to be passed to level 2 screening. The full-text for 29 articles could not be obtained in time to be screened for this review and were added to the inventory of potentially relevant articles. Of the 127 articles screened at level 2, 74 were passed to data abstraction. During data abstraction a further 20 articles were excluded due to lack of relevant outcomes, leaving 54 articles included in this review (Figure 1). 
medRxiv preprint doi: https://doi.org/10.1101/2020.03.19.20039008; this version posted March 25, 2020. The copyright holder for this preprint (which was not certified by peer review) is the author/funder, who has granted medRxiv a license to display the preprint in perpetuity.

It is made available under a CC-BY-NC-ND 4.0 International license .

Figure 1: Study Flow Diagram

Citations identified through database search

$(n=4,491)$

Citations identified through other sources

$$
(n=313)
$$

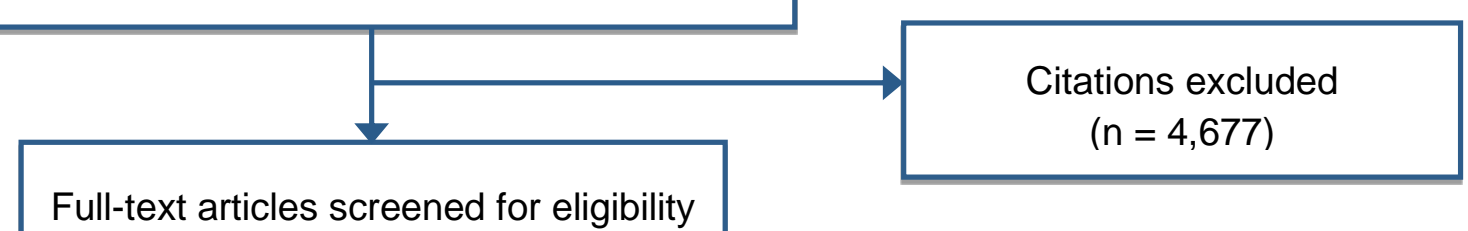

Full-text articles screened for eligibility

$(n=127)$

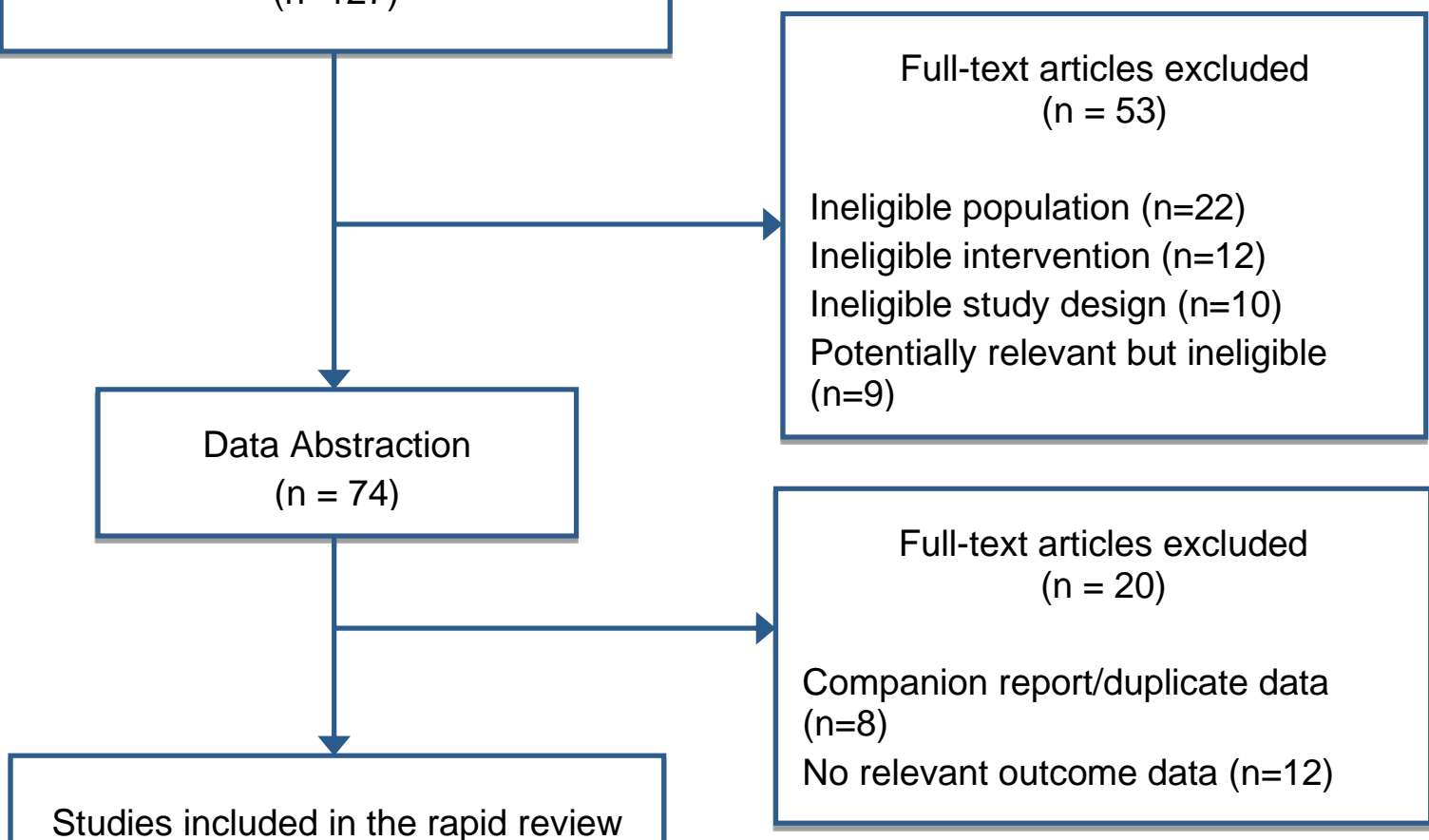

\section{Characteristics of included studies}

Of the 54 studies included in this review three were controlled trials ${ }^{6-8}, 10$ were cohort studies $^{9-}$ ${ }^{18}$, seven were retrospective medical record/database studies ${ }^{19-25}$, and 34 were case reports or case series $^{26-59}$ (Table 2). All of the included studies were published between 2003 and 2020 with the majority conducted in Hong Kong $(n=14)$, followed by China $(n=12)$, Saudi Arabia $(n=10)$, Canada $(n=5)$, South Korea $(n=4)$, Taiwan $(n=3)$, and one each from France, Germany, Greece, the United Arab Emirates, and the United States. Sample sizes for the studies ranged from single patients in the case reports to groups of $>1000$ patients in the cohort studies. Overall, the majority of studies $(n=33)$ dealt with treatment of Severe Acute Respiratory Syndrome (SARS), followed by Middle East Respiratory Syndrome (MERS; n=16), COVID-19 $(n=3)$ and two studies treated unspecified coronavirus. 
medRxiv preprint doi: https://doi.org/10.1101/2020.03.19.20039008; this version posted March 25, 2020. The copyright holder for this preprint (which was not certified by peer review) is the author/funder, who has granted medRxiv a license to display the preprint in perpetuity.

It is made available under a CC-BY-NC-ND 4.0 International license.

The majority of studies were conducted in adult populations $(n=52)$, one case report ${ }^{31}$ and one case series ${ }^{36}$ included infant and pediatric populations, respectively. Four case reports/series ${ }^{29,45,46,48}$ specifically included immunocompromised patients and one case study ${ }^{34}$ included a pregnant woman with MERS; however, the majority of study populations included patients with comorbid conditions $(n=33)$. Common comorbidities included diabetes, heart disease, hypertension, and renal failure (Appendix 3). The most common antiviral studied was ribavirin $(n=41)$, followed by oseltamivir $(n=10)$ and the combination of lopinavir/ritonavir $(n=7)$. Additional therapies used in the studies included a variety of broad spectrum antibiotics $(n=30)$, steroids including hyrdcortisone, methylprednisone, or prednisolone $(n=39)$ or various interferons ( $n=12$; Appendix 3 ). No animal or human trials investigating monoclonal antibodies for the treatment of COVID-19 were found in this rapid review. All of the studies recruited from or reported on hospitalized populations and the most commonly reported outcome was mortality $(n=40)$, followed by ICU admission $(n=21)$ and adverse events $(n=18)$.

Table 2: Summary Study and Patient Characteristics

\begin{tabular}{|c|c|c|c|c|}
\hline Characteristics (n) & $\begin{array}{l}\text { Controlled } \\
\text { Trials ( } n=3)\end{array}$ & $\begin{array}{l}\text { Cohort Studies } \\
\qquad(n=10)\end{array}$ & $\begin{array}{l}\text { Retrospective } \\
\text { Studies }(n=7)\end{array}$ & $\begin{array}{c}\text { Case } \\
\text { Reports/Series } \\
(n=34)\end{array}$ \\
\hline \multicolumn{5}{|l|}{ Diagnosis } \\
\hline COVID-19 & -- & -- & -- & 3 \\
\hline SARS & 2 & 7 & 4 & 20 \\
\hline MERS & 1 & 3 & 3 & 9 \\
\hline Other coronavirus & -- & -- & -- & 2 \\
\hline $\begin{array}{l}\text { Age of population } \\
\text { (range) }\end{array}$ & 22 to 57 & 15 to 70 & 22 to 79 & $\begin{array}{c}4 \text { months to } 83 \\
\text { years }\end{array}$ \\
\hline $\begin{array}{l}\text { Sample size } \\
\text { [median (range)] }\end{array}$ & 43 (16 to 190$)$ & $\begin{array}{c}169(72 \text { to } \\
1934)\end{array}$ & 63 (14 to 306$)$ & 8 (1 to 323$)$ \\
\hline $\begin{array}{l}\text { Publication Year } \\
\text { (range) }\end{array}$ & 2004 to 2019 & 2003 to 2019 & 2003 to 2019 & 2003 to 2020 \\
\hline $\begin{array}{l}\text { Country of } \\
\text { conduct }\end{array}$ & $\begin{array}{c}\text { China (2), South } \\
\text { Korea (1) }\end{array}$ & $\begin{array}{l}\text { China (3), Hong } \\
\text { Kong (3), South } \\
\text { Korea (1), Saudi } \\
\text { Arabia (2), } \\
\text { Singapore (1) }\end{array}$ & $\begin{array}{c}\text { Canada (2), } \\
\text { Saudi Arabia (3), } \\
\text { Taiwan (2) }\end{array}$ & $\begin{array}{c}\text { Canada (3), } \\
\text { China (7), } \\
\text { France (1), } \\
\text { Germany (1), } \\
\text { Greece (1), } \\
\text { Hong Kong (11), } \\
\text { South Korea (2), } \\
\text { Saudi Arabia (5), } \\
\text { Taiwan (1), } \\
\text { United Arab } \\
\text { Emirates (1), } \\
\text { USA (1) }\end{array}$ \\
\hline $\begin{array}{l}\text { Comorbidities } \\
\text { reported in study } \\
\text { population }\end{array}$ & No (3) & Yes (6); No (4) & Yes (5), No (2) & $\begin{array}{c}\text { Yes (22), No } \\
(12)\end{array}$ \\
\hline Interventions & & 9 & & \\
\hline Ribavirin & 3 & 2 & 7 & 29 \\
\hline Oseltamivir & -- & 2 & 1 & 7 \\
\hline Lopinavir/ritonavir & 1 & 2 & 1 & 3 \\
\hline
\end{tabular}


medRxiv preprint doi: https://doi.org/10.1101/2020.03.19.20039008; this version posted March 25, 2020. The copyright holder for this preprint (which was not certified by peer review) is the author/funder, who has granted medRxiv a license to display the preprint in perpetuity.

It is made available under a CC-BY-NC-ND 4.0 International license .

\begin{tabular}{|ccccc|}
\hline Foscarnet & -- & -- & -- & 1 \\
Remdesivir & -- & -- & -- & 1 \\
Antibiotics & 2 & 3 & 3 & 22 \\
Steroids & 2 & 10 & 5 & 22 \\
Interferons & 1 & 3 & 2 & 6 \\
\hline
\end{tabular}

\section{Risk of Bias Results}

The 34 case reports/series and 7 retrospective studies included in this review were not assessed for risk of bias due to the inherent bias in the type of study design. The 3 trials were assessed with the Cochrane RoB tool ${ }^{4}$ and the 10 cohort studies were assessed using the NOS $^{5}$. The risk of bias in the 3 included trials was overall difficult to judge due to a lack of adequate descriptions of study methods (Figure 2). All three of the trials were at high or unclear risk of bias on the following components: random sequence generation, allocation concealment, and blinding of participants/personnel (Appendix 5). The cohort studies were of fair quality overall; most of the studies suffered from a lack of representative sampling $(n=8)$, failed to demonstrate that the outcomes of interest were not present at the start of the study $(n=8)$, or failed to adequately ensure the comparability of cohorts ( $n=4$; Figure 3 ). The complete NOS results are provided in Appendix 5. 
medRxiv preprint doi: https://doi.org/10.1101/2020.03.19.20039008; this version posted March 25, 2020. The copyright holder for this preprint (which was not certified by peer review) is the author/funder, who has granted medRxiv a license to display the preprint in perpetuity.

It is made available under a CC-BY-NC-ND 4.0 International license .

Figure 2 Cochrane RoB results - Controlled trials ( $n=3)$

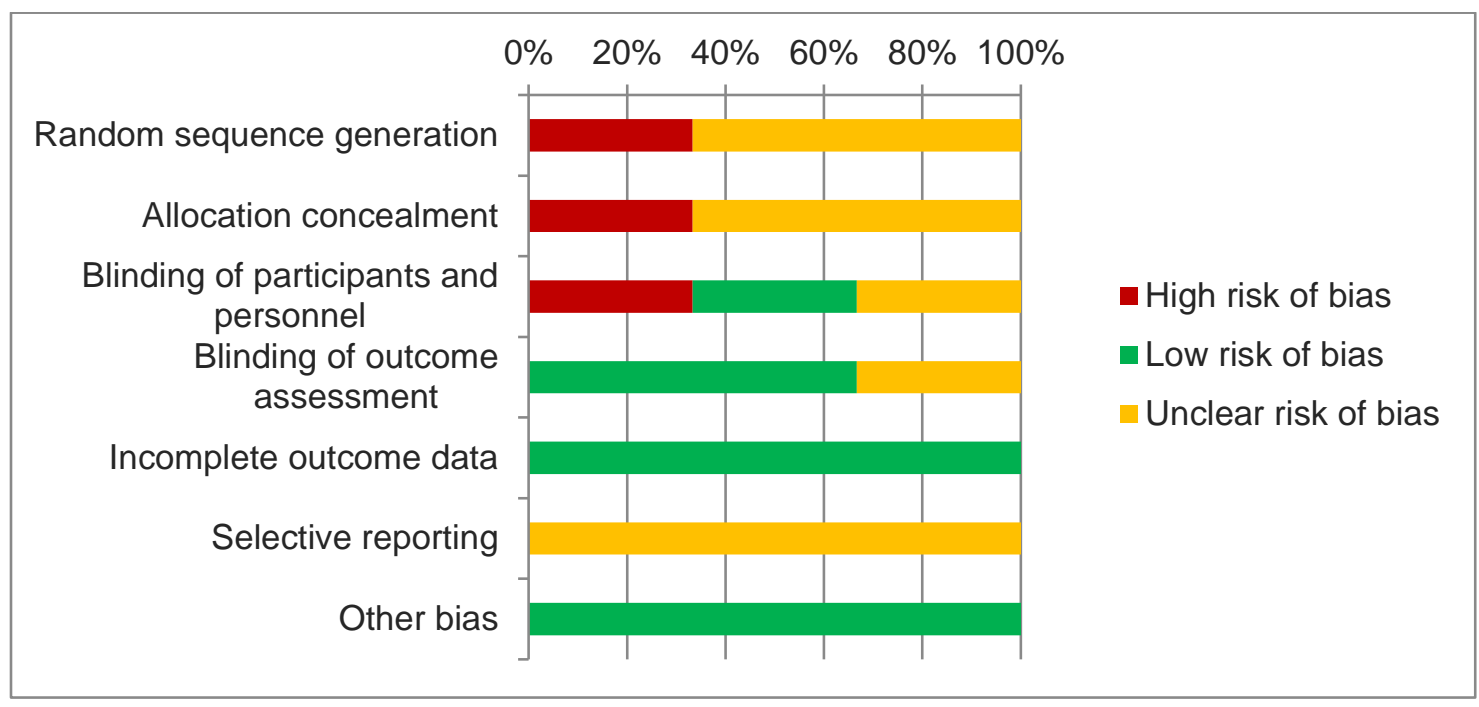

Figure 3: NOS Results - Cohort studies ( $n=10)$

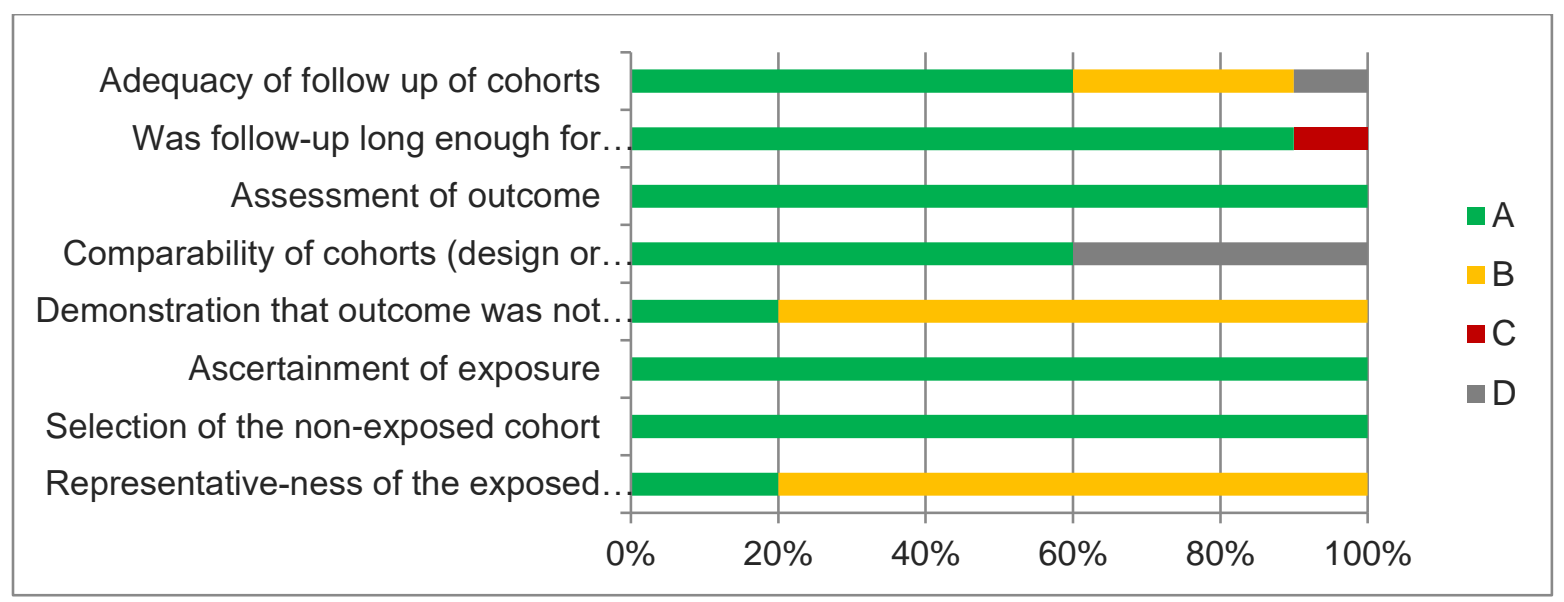

\section{Studies of COVID-19}

Three studies examining patients infected with COVID-19 were included in this review: one case report $^{35}$ and two case series ${ }^{56,57}$.

The case report ${ }^{35}$ included a 35-year-year old man, the first American diagnosed with COVID19. He, he was initially treated with vancomycin and cefepime which are standard treatments for suspected community-acquired pneumonia. Upon lab-confirmation of COVID-19 infection, the antibiotics were stopped and the patient was started on Remdesivir 7 days after initial admission to hospital. At study end, the patient remained hospitalized with the majority of symptoms resolved (see appendices 3 and 4 for complete details).

The two case series ${ }^{56,57}$ were conducted in China and included 4 and 138 patients, respectively. All patients were hospitalized and initial diagnosis was made based on WHO Criteria later confirmed by lab-testing of the patient specimens. The case series included an approximately even number of male and female (55\% v 45\%) patients ranging in age from 19 to 68 years old, 
medRxiv preprint doi: https://doi.org/10.1101/2020.03.19.20039008; this version posted March 25, 2020. The copyright holder for this preprint (which was not certified by peer review) is the author/funder, who has granted medRxiv a license to display the preprint in perpetuity.

It is made available under a CC-BY-NC-ND 4.0 International license.

with a variety of co-morbidities including cardiovascular disease, chronic kidney or liver disease, COPD, and diabetes (Appendix 3$)$. In one case series ${ }^{57}$, patients $(n=4)$ were treated with a combination of lopinavir/ritonavir, Arbidol (umifenovir), antibiotics, Shufeng Jiedu Capsule (Traditional Chinese Medicine), and intravenous immunoglobulins (Appendix 4). At study end (15 days),) two patients tested negative for COVID-19 and were subsequently discharged from the hospital and two patients remained hospitalized, one of whom still required mechanical ventilation (Appendix 4). In the larger case series ${ }^{56}, 124$ patients were treated with oseltamivir combined with antibiotic therapy in 89 patients and combined with glucocorticoids in 62 patients (Appendix 4). Over the course of the study, 34 patients treated with oseltamivir were admitted to the ICU, 17 of which required invasive mechanical ventilation. At study end (19 days),) 47 patients had been discharged and 6 patients died, all of whom had been admitted to ICU (Appendix 4).

\section{Ongoing human trials for COVID-19}

Four currently ongoing randomized controlled trials proposing to test treatments for COVID-19 were identified through keyword searches of clinicaltrials.gov. All four trials are being carried out in China, three are investigating antiviral medications (lopinavir/ritonavir, arbidol (umifenovir), darunavir, cobicstat, and, ASC09/ritonavir) and one trial is investigating a combination of lopinavir/ritonavir with Traditional Chinese Medicines (TCM). At the time of this writing two of the trials have started recruiting patients (further details in Table 3).

Table 3: Details of ongoing COVID-19 trials

\begin{tabular}{|c|c|c|}
\hline $\begin{array}{l}\text { Author, Year } \\
\text { Country } \\
\text { NCT ID }\end{array}$ & $\begin{array}{c}\text { Status } \\
\text { Estimated Enrollment } \\
\text { Estimated completion }\end{array}$ & $\begin{array}{l}\text { Eligibility Criteria (age; diagnosis) } \\
\text { Interventions }\end{array}$ \\
\hline $\begin{array}{l}\text { Li, } 2020 \\
\text { China } \\
\text { NCT04252885 }\end{array}$ & $\begin{array}{l}\text { Recruiting } \\
125 \text { participants } \\
\text { July } 31,2020\end{array}$ & $\begin{array}{l}\text { Adult (18-80 yrs); lab-confirmed infection } \\
\text { Group A: standard treatment + lopinavir/ritonavir } \\
\text { Group B; standard treatment + arbidol (umifenovir) } \\
\text { Group C: standard treatment }\end{array}$ \\
\hline $\begin{array}{l}\text { Lu, } 2020 \\
\text { China } \\
\text { NCT04252274 }\end{array}$ & $\begin{array}{l}\text { Not yet recruiting } \\
30 \text { participants } \\
\text { December } 31,2020\end{array}$ & $\begin{array}{l}\text { All ages; National Health Commission diagnostic criteria } \\
\text { Intervention: Darunavir, Cobicistat + conventional } \\
\text { treatments } \\
\text { Comparator: Conventional treatments }\end{array}$ \\
\hline $\begin{array}{l}\text { Qiu, } 2020 \\
\text { China } \\
\text { NCT04261907 }\end{array}$ & $\begin{array}{l}\text { Not yet recruiting } \\
160 \text { participants } \\
\text { June } 30,2020\end{array}$ & $\begin{array}{l}\text { Adult (18-75 yrs); lab-confirmed infection } \\
\text { Intervention: ASC09/ritonavir + conventional treatment } \\
\text { Comparator: lopinavir/ritonavir + conventional treatment }\end{array}$ \\
\hline $\begin{array}{l}\text { Xiao, } 2020 \\
\text { China } \\
\text { NCT04251871 }\end{array}$ & $\begin{array}{l}\text { Recruiting } \\
150 \text { participants } \\
\text { January } 22,2021\end{array}$ & $\begin{array}{l}\text { Youth/Adult (14-80 yrs); lab-confirmed infection } \\
\text { Intervention: TCM + conventional medicines } \\
\text { Comparator: Conventional medicines } \\
{ }^{\star *}\end{array}$ \\
\hline
\end{tabular}

${ }^{* *}$ Conventional medicines includes: oxygen therapy, antiviral therapy (alfa interferon via aerosol inhalation, and lopinavir/ritonavir, 400mg/100mg, p.o, bid)

\section{Effectiveness Outcomes}

Infection Prevention

One of the included trials ${ }^{7}$ examined the effectiveness of ribavirin combined with lopinavir/ritonavir compared to no treatment as a prophylactic measure for healthcare workers highly exposed to MERS through unprotected exposure to a patient with pneumonia later 
medRxiv preprint doi: https://doi.org/10.1101/2020.03.19.20039008; this version posted March 25, 2020. The copyright holder for this preprint (which was not certified by peer review) is the author/funder, who has granted medRxiv a license to display the preprint in perpetuity.

It is made available under a CC-BY-NC-ND4.0 International license.

confirmed to be caused by MERS-CoV. None of the subjects in the prophylaxis arm (ribavirin/lopinavir/ritonavir) developed MERS while 6 subjects in the control arm were infected with MERS as confirmed by rPT-PCR testing. The risk of infection was statistically significantly lower in the prophylaxis arm (adjusted odds ratio: $0.405,95 \% \mathrm{Cl} 0.274$ to $0.599, \mathrm{p}=0.009$; Appendix 4).

\section{ICU Admission}

Of the 21 studies reporting this outcome, one was a randomized trial ${ }^{6}$ comparing ribavirin supplemented with hydrocortisone to ribavirin alone; three were cohort studies ${ }^{14,15,17}$ comparing oseltamivir to steroid treatment alone, ribavirin with continuous steroid treatment to ribavirin with high-dose 'pulse' steroids, and ribavirin to steroid and/or antibiotic treatment; three were retrospective studies ${ }^{19,20,25}$ examining the effectiveness of ribavirin and oseltamivir alone or in combination with other drugs; and 14 were case reports/series $33,34,37,40,42,44,45,47,50,51,53,55-57$ examining ribavirin, oseltamivir, lopinavir/ritonavir alone or in combination with steroids or antibiotics. None of the trials, cohorts, or retrospective studies demonstrated statistically significant results between any of the comparisons (i.e., in favour of or against the effectiveness of ribavirin, oseltamivir or lopinavir/ritonavir) in reducing the risk of ICU admission for patients with SARS or MERS. The case reports and series were similarly inconclusive, none of the study authors reported a particular advantage for patients with COVID-19, SARS, or MERS treated with ribavirin, oseltamivir, or lopinavir/ritonavir.

\section{Special populations}

One case series ${ }^{45}$ included 4 patients with hematological malignancies that acquired MERS infections. The patients were all treated with oseltamivir and one patient required admission to the ICU due to worsening symptoms. One case report ${ }^{34}$ of a pregnant woman with MERS described initially attempting treatment with antibiotics but the patient did not respond and was transferred to ICU where antiviral treatments were initiated but the patient continued to deteriorate and died. In a case series ${ }^{36}$ of 4 pediatric patients with SARS, all 4 were treated with ribavirin and 2 patients required mechanical ventilation during the course of their illness.

\section{Mortality}

Mortality was reported in two of the included trials (ribavirin), all 10 cohort studies (ribavirin, lopinavir/ritonavir, oseltamivir), all seven retrospective studies (ribavirin, lopinavir/ritonavir, oseltamivir), and 21 case reports or case series (ribavirin, oseltamivir, lopinavir/ritonavir). The comparative studies (trials and cohorts) failed to find statistically significant results indicating that none of the antivirals they examined were effective in reducing mortality for SARS or MERS. One cohort study ${ }^{10}$ of MERS patients found that treatment with ribavirin and interferons significantly increased 90-day mortality risk (adjusted odds ratio: 2.27, 95\% Cl 1.20-4.32). The patients in this cohort were generally older (median age 57 (IQR 47-70)) and had a number of underlying chronic conditions including diabetes, cardiovascular disease, chronic lung, renal, or liver disease and malignancy including leukemia or lymphoma which may in part explain the increased risk. One retrospective study ${ }^{20}$ of SARS patients found the 21-day mortality rate was significantly higher in a cohort of patients treated with ribavirin compared to matched historical controls $(6.5 \%, 95 \% \mathrm{Cl} 1.9 \%$ to $11.8 \%$ ). Patients in this study were largely middle aged (34 to 57 years of age); however a large proportion of patients that died (approximately $80 \%$ ) had underlying conditions such as diabetes or cancer. 
medRxiv preprint doi: https://doi.org/10.1101/2020.03.19.20039008; this version posted March 25, 2020. The copyright holder for this preprint (which was not certified by peer review) is the author/funder, who has granted medRxiv a license to display the preprint in perpetuity.

It is made available under a CC-BY-NC-ND4.0 International license.

The two case series ${ }^{56,57}$ and one case report ${ }^{35}$ that included patients with COVID-19 that used Remdesivir (1 patient), lopinavir/ritonavir (4 cases) and oseltamivir (124 cases) reported 6 deaths in the cohort treated with oseltamivir.

\section{Special Populations}

The four cases reports/series ${ }^{29,45,46,48}$ that included immunosuppressed patients with MERS (5 patients) and unspecified coronavirus (2 patients) reported 3 deaths all in patients with hematological malignancies treated with foscarnet $(n=1)$ and oseltamivir $(n=2)$. One patient with HIV and 2 patients with hematological malignancies that acquired MERS were treated with ribavirin and oseltamivir respectively and survived after being hospitalized for their illness (38 and 28 days respectively). The case report ${ }^{34}$ of a pregnant woman with MERS treated with oseltamivir and later ribavirin succumbed to septic shock 8 days after admission to hospital. The two case series ${ }^{31,36}$ that included pediatric patients treated with ribavirin reported no mortality at study end.

\section{Safety Outcomes}

\section{Adverse Events}

One of the included trials ${ }^{7}$, seven of the cohort studies ${ }^{9-11,13-15,17}$, three of the retrospective studies $^{20,21,25}$, and seven case reports/series ${ }^{28,38,39,42,43,50,51}$ reported treatment related adverse events while two retrospective studies and three case reports/series reported that no treatment related adverse events occurred. In the trial ${ }^{7}$ examining the effectiveness of ribavirin/lopinavir/ritonavir compared to no treatment as a prophylactic measure for healthcare workers, treatment-related adverse events were widely reported in the prophylaxis arm, including: Gl symptoms (diarrhea $n=9$, nausea $n=9$, stomatitis $n=4)$, anemia $(n=9)$, leucopenia $(n=8)$ and hyperbilirubinemia $(n=20)$. All adverse effects occurred during prophylactic therapy and resolved shortly after conclusion of treatment with no further intervention. Overall, the most commonly reported adverse events were anemia ( $n=12$ studies) and altered liver function $(n=5$ studies) in patients treated with ribavirin. Other treatment related adverse events included gastrointestinal symptoms (e.g., nausea, vomiting), changes in kidney function, cardiac events (e.g., bradycardia, atrial fibrillation), hyperglycemia, and changes in mental status (e.g., confusion, anxiety). It should be noted however, that in the studies reporting cardiac adverse events, hyperglycemia, and mental status changes patients were receiving steroids as well as ribavirin.

\section{Special Populations}

None of the studies that included special populations reported treatment-related adverse events.

\section{DISCUSSION}

The Public Health Agency of Canada commissioned a rapid review to address the urgent question of the effectiveness and safety of antiviral or antibody therapies in the treatment of coronavirus. A comprehensive literature search of both electronic databases and grey literature sources resulted in 54 studies of various antiviral treatments in patients diagnosed with COVID- 
medRxiv preprint doi: https://doi.org/10.1101/2020.03.19.20039008; this version posted March 25, 2020. The copyright holder for this preprint (which was not certified by peer review) is the author/funder, who has granted medRxiv a license to display the preprint in perpetuity.

It is made available under a CC-BY-NC-ND 4.0 International license.

19, SARS, or MERS; however, no animal or human studies of monoclonal antibodies could be ST. MICHAEL'S UNITY HEALTH TORONTO found.

Overall the results of the included studies proved inconclusive on the effectiveness of antiviral drugs in treating coronavirus infections and prevent any particular treatments from being recommended for use. There is a low quality of available evidence that largely consists of case reports and case series, with few observational studies, and even fewer trials. There were however important safety signals identified in the included studies, particularly the possible development of anemia and altered liver function in patients receiving ribavirin treatment. It is similarly difficult to recommend a particular antiviral drug as a promising candidate for further investigation due to the variable quality and inconclusive results of the current evidence. This review does show however that the existing body of evidence is weighted heavily towards studies of ribavirin which has shown no particular efficacy in treating coronavirus and may in fact cause harmful adverse effects. Future investigations into potential antiviral therapies for coronavirus may be best served by pointing their attention to other drug candidates.

There are several limitations to the review methods employed here, single screening and abstraction for example, however they were selected to thoughtfully tailor our methods according to our knowledge user needs and the urgent nature of the request to provide timely results.

\section{CONCLUSIONS}

The current evidence for the effectiveness of antiviral therapies for coronavirus is not conclusive and suffers from a lack of well-designed prospective trials or observational studies. None of the interventions examined in this review can be recommended for use in patients with coronavirus. Similarly, no firm recommendations can be made for or against these interventions from a safety perspective due to a lack of conclusive evidence. Some important safety signals potentially related to ribavirin use were identified (anemia, altered liver function) but also require further investigation to clarify their relation to the drug. 
medRxiv preprint doi: https://doi.org/10.1101/2020.03.19.20039008; this version posted March 25, 2020. The copyright holder for this preprint (which was not certified by peer review) is the author/funder, who has granted medRxiv a license to display the preprint in perpetuity.

It is made available under a CC-BY-NC-ND4.0 International license .

\section{REFERENCES}

1. Collaboration TC. Cochrane Handbook for Systematic Reviews of Interventions. http://training.cochrane.org/handbook. Accessed 25 October 2017.

2. Tricco AC LE, Straus SE, ed Rapid reviews to strengthen health policy and systems: a practical guide. Geneva: World Health Organization; 2017.

3. Moher D, Liberati A, Tetzlaff J, Altman DG. Preferred reporting items for systematic reviews and meta-analyses: the PRISMA statement. Annals of internal medicine. 2009;151(4):264-269.

4. Higgins JP, Altman DG, Gotzsche PC, et al. The Cochrane Collaboration's tool for assessing risk of bias in randomised trials. BMJ (Clinical research ed). 2011;343:d5928.

5. GA W, B S, D OC, et al. The Newcastle-Ottawa Scale (NOS) for assessing the quality of nonrandomised studies in meta-analyses.

http://www.ohri.ca/programs/clinical epidemiology/oxford.asp. Accessed 25 October 2017.

6. Lee N, Allen Chan KC, Hui DS, et al. Effects of early corticosteroid treatment on plasma SARS-associated Coronavirus RNA concentrations in adult patients. Journal of clinical virology : the official publication of the Pan American Society for Clinical Virology. 2004;31(4):304-309.

7. Park SY, Lee JS, Son JS, et al. Post-exposure prophylaxis for Middle East respiratory syndrome in healthcare workers. The Journal of hospital infection. 2019;101(1):42-46.

8. Zhao Z, Zhang F, Xu M, et al. Description and clinical treatment of an early outbreak of severe acute respiratory syndrome (SARS) in Guangzhou, PR China. Journal of medical microbiology. 2003;52(Pt 8):715-720.

9. Alkhadhairi E; Alzubairy S; Abuzaid MA, A. Ribavirin plus interferon in the management of Middle East respiratory syndrome coronavirus: a historical control study of 113 patients [Corrigendum to 2017 ACCP Annual Meeting]. Pharmacotherapy. 2018;38(4):483.

10. Arabi YM, Shalhoub S, Mandourah Y, et al. Ribavirin and Interferon Therapy for Critically III Patients With Middle East Respiratory Syndrome: A Multicenter Observational Study. Clinical infectious diseases : an official publication of the Infectious Diseases Society of America. 2019.

11. Chan KS, Lai ST, Chu CM, et al. Treatment of severe acute respiratory syndrome with lopinavir/ritonavir: a multicentre retrospective matched cohort study. Hong Kong medical journal = Xianggang yi xue za zhi. 2003;9(6):399-406.

12. Choi WS, Kang Cl, Kim Y, et al. Clinical Presentation and Outcomes of Middle East Respiratory Syndrome in the Republic of Korea. Infection \& chemotherapy. 2016;48(2):118-126.

13. Chu CM, Cheng VC, Hung IF, et al. Role of lopinavir/ritonavir in the treatment of SARS: initial virological and clinical findings. Thorax. 2004;59(3):252-256.

14. Guo L, Han Y, Li J, et al. Long-term outcomes in patients with severe acute respiratory syndrome treated with oseltamivir: a 12-year longitudinal study. INTERNATIONAL JOURNAL OF CLINICAL AND EXPERIMENTAL MEDICINE. 2019;12(10):12464-12471.

15. Ho JC, Ooi GC, Mok TY, et al. High-dose pulse versus nonpulse corticosteroid regimens in severe acute respiratory syndrome. American journal of respiratory and critical care medicine. 2003;168(12):1449-1456.

16. Lau EH, Cowling BJ, Muller MP, et al. Effectiveness of ribavirin and corticosteroids for severe acute respiratory syndrome. The American journal of medicine.

2009;122(12):1150.e1111-1121. 
medRxiv preprint doi: https://doi.org/10.1101/2020.03.19.20039008; this version posted March 25, 2020. The copyright holder for this preprint (which was not certified by peer review) is the author/funder, who has granted medRxiv a license to display the preprint in perpetuity.

It is made available under a CC-BY-NC-ND4.0 International license .

17. Leong HN, Ang B, Earnest A, Teoh C, Xu W, Leo YS. Investigational use of ribavirin in the treatment of severe acute respiratory syndrome, Singapore, 2003. Tropical medicine \& international health : TM \& IH. 2004;9(8):923-927.

18. Li S, Wang R, Zhang $Y$, et al. Symptom combinations associated with outcome and therapeutic effects in a cohort of cases with SARS. The American journal of Chinese medicine. 2006;34(6):937-947.

19. Alhumaid S, Tobaiqy M, Albagshi M, et al. MERS-CoV transmitted from animal-tohuman vs MERSCoV transmitted from human-to-human: Comparison of virulence and therapeutic outcomes in a Saudi hospital. Tropical Journal of Pharmaceutical Research. 2018;17(6):1155-1164.

20. Booth CM, Matukas LM, Tomlinson GA, et al. Clinical features and short-term outcomes of 144 patients with SARS in the greater Toronto area. Jama. 2003;289(21):2801-2809.

21. Chiou HE, Liu CL, Buttrey MJ, et al. Adverse effects of ribavirin and outcome in severe acute respiratory syndrome: experience in two medical centers. Chest. 2005;128(1):263272.

22. Habib AMG, Ali MAE, Zouaoui BR, Taha MAH, Mohammed BS, Saquib N. Clinical outcomes among hospital patients with Middle East respiratory syndrome coronavirus (MERS-CoV) infection. BMC infectious diseases. 2019;19(1):870.

23. Khalid I, Alraddadi BM, Dairi Y, et al. Acute Management and Long-Term Survival Among Subjects With Severe Middle East Respiratory Syndrome Coronavirus Pneumonia and ARDS. Respiratory care. 2016;61(3):340-348.

24. Liu CY, Huang LJ, Lai CH, et al. Clinical characteristics, management and prognostic factors in patients with probable severe acute respiratory syndrome (SARS) in a SARS center in Taiwan. Journal of the Chinese Medical Association : JCMA. 2005;68(3):110117.

25. Muller MP, Dresser L, Raboud J, et al. Adverse events associated with high-dose ribavirin: evidence from the Toronto outbreak of severe acute respiratory syndrome. Pharmacotherapy. 2007;27(4):494-503.

26. Al-Tawfiq JA, Hinedi K. The calm before the storm: clinical observations of Middle East respiratory syndrome (MERS) patients. Journal of chemotherapy (Florence, Italy). 2018;30(3):179-182.

27. Al-Tawfiq JA, Momattin H, Dib J, Memish ZA. Ribavirin and interferon therapy in patients infected with the Middle East respiratory syndrome coronavirus: an observational study. International journal of infectious diseases : IJID : official publication of the International Society for Infectious Diseases. 2014;20:42-46.

28. Avendano M, Derkach $\mathrm{P}$, Swan S. Clinical course and management of SARS in health care workers in Toronto: a case series. CMAJ : Canadian Medical Association journal = journal de l'Association medicale canadienne. 2003;168(13):1649-1660.

29. Bogdanov R, Koeppen S, Beelen DW, Steckel NK. Coronavirus-encephalitis after Haploidentical Hematopoetic Stem Cell Transplantation (haplo-HSCT). Oncology Research and Treatment. 2017;40 (Supplement 3):62-63.

30. Cheng FW, $\mathrm{Ng} \mathrm{EK}$, Li AM, et al. Clinical, virologic and immunologic profiles of a young infant with severe acute respiratory syndrome. The Pediatric infectious disease journal. 2005;24(6):567-568.

31. Cheng WT, Li CK, Leung TF, et al. Ribavirin for SARS in children. Clinical pediatrics. 2004;43(2):193-196.

32. Chiang $\mathrm{CH}$, Chen HM, Shih JF, Su WJ, Perng RP. Management of hospital-acquired severe acute respiratory syndrome with different disease spectrum. Journal of the Chinese Medical Association : JCMA. 2003;66(6):328-338.

33. Gomersall CD, Joynt GM, Lam P, et al. Short-term outcome of critically ill patients with severe acute respiratory syndrome. Intensive care medicine. 2004;30(3):381-387. 
medRxiv preprint doi: https://doi.org/10.1101/2020.03.19.20039008; this version posted March 25, 2020. The copyright holder for this preprint (which was not certified by peer review) is the author/funder, who has granted medRxiv a license to display the preprint in perpetuity.

It is made available under a CC-BY-NC-ND 4.0 International license .

34. Habib Z, Asghar F, El Masry K, El Reddy M, Ravi M. MERS-CoV in pregnancy. BJOG: An International Journal of Obstetrics and Gynaecology. 2015;2):274.

35. Holshue ML, DeBolt C, Lindquist S, et al. First Case of 2019 Novel Coronavirus in the United States. The New England journal of medicine. 2020.

36. Hon KL, Leung CW, Cheng WT, et al. Clinical presentations and outcome of severe acute respiratory syndrome in children. Lancet (London, England).

2003;361(9370):1701-1703.

37. Khalid I, Kadri M, Dairi Y, et al. Outcome of intubated patients with middle east respiratory syndrome coronavirus pneumonia and acute respiratory distress syndrome in a tertiary care hospital in Saudi Arabia. American Journal of Respiratory and Critical Care Medicine Conference: American Thoracic Society International Conference, ATS. 2015;191(MeetingAbstracts).

38. Kim I, Lee JE, Kim KH, Lee S, Lee K, Mok JH. Successful treatment of suspected organizing pneumonia in a patient with Middle East respiratory syndrome coronavirus infection: a case report. Journal of thoracic disease. 2016;8(10):E1190-e1194.

39. Knowles SR, Phillips EJ, Dresser L, Matukas L. Common adverse events associated with the use of ribavirin for severe acute respiratory syndrome in Canada. Clinical infectious diseases : an official publication of the Infectious Diseases Society of America. 2003;37(8):1139-1142.

40. Kwan BC, Leung CB, Szeto CC, et al. Severe acute respiratory syndrome in dialysis patients. Journal of the American Society of Nephrology : JASN. 2004;15(7):1883-1888.

41. Lam MF, Ooi GC, Lam B, et al. An indolent case of severe acute respiratory syndrome. American journal of respiratory and critical care medicine. 2004;169(1):125-128.

42. Lau AC, So LK, Miu FP, et al. Outcome of coronavirus-associated severe acute respiratory syndrome using a standard treatment protocol. Respirology (Carlton, Vic). 2004;9(2):173-183.

43. Lee JY, Kim YJ, Chung EH, et al. The clinical and virological features of the first imported case causing MERS-CoV outbreak in South Korea, 2015. BMC infectious diseases. 2017;17(1):498.

44. Lopez V, Chan KS, Wong YC. Nursing care of patients with severe acute respiratory syndrome in the intensive care unit: case reports in Hong Kong. International journal of nursing studies. 2004;41(3):263-272.

45. Motabi IH, Zaidi SZA, Ibrahim MH, et al. Report of middle east respiratory syndrome coronavirus (MERSCoV) infection in four patients with hematological malignancies treated at king fahad medical City, Riyadh, Saudi Arabia. Blood Conference: 58th Annual Meeting of the American Society of Hematology, ASH. 2016;128(22).

46. Oger C, Lefebure A, Martelli S, Brugiere O, Lhuillier E, Arnaud P. Effectiveness of oral ribavirin in immunocompromised adults with respiratory viral infections. International Journal of Clinical Pharmacy. 2017;39 (1):298.

47. Poutanen SM, Low DE, Henry B, et al. Identification of severe acute respiratory syndrome in Canada. The New England journal of medicine. 2003;348(20):1995-2005.

48. Shalhoub S, AlZahrani A, Simhairi R, Mushtaq A. Successful recovery of MERS CoV pneumonia in a patient with acquired immunodeficiency syndrome: a case report. Journal of clinical virology : the official publication of the Pan American Society for Clinical Virology. 2015;62:69-71.

49. So LK, Lau AC, Yam LY, et al. Development of a standard treatment protocol for severe acute respiratory syndrome. Lancet (London, England). 2003;361(9369):1615-1617.

50. Spanakis N, Tsiodras S, Haagmans BL, et al. Virological and serological analysis of a recent Middle East respiratory syndrome coronavirus infection case on a triple combination antiviral regimen. International journal of antimicrobial agents. 2014;44(6):528-532. 
medRxiv preprint doi: https://doi.org/10.1101/2020.03.19.20039008; this version posted March 25, 2020. The copyright holder for this preprint (which was not certified by peer review) is the author/funder, who has granted medRxiv a license to display the preprint in perpetuity. It is made available under a CC-BY-NC-ND 4.0 International license.

51. Sung JJ, Wu A, Joynt GM, et al. Severe acute respiratory syndrome: report of ST. MICHAE
UNITY HEALTH TORO
atory syndrome: report of
ax. 2004;59(5):414-420.

52. Tang HL, Cheuk $\mathrm{A}$, Chu $\mathrm{KH}$, et al. Severe acute respiratory syndrome in haemodialysis patients: a report of two cases. Nephrology, dialysis, transplantation : official publication of the European Dialysis and Transplant Association - European Renal Association. 2003;18(10):2178-2181.

53. Tiwari A, Chan S, Wong A, et al. Severe acute respiratory syndrome (SARS) in Hong Kong: patients' experiences. Nursing outlook. 2003;51(5):212-219.

54. Tsang KW, Ho PL, Ooi GC, et al. A cluster of cases of severe acute respiratory syndrome in Hong Kong. The New England journal of medicine. 2003;348(20):19771985.

55. Tsui PT, Kwok ML, Yuen H, Lai ST. Severe acute respiratory syndrome: clinical outcome and prognostic correlates. Emerging infectious diseases. 2003;9(9):1064-1069.

56. Wang D, Hu B, Hu C, et al. Clinical Characteristics of 138 Hospitalized Patients With 2019 Novel Coronavirus-Infected Pneumonia in Wuhan, China. Jama. 2020.

57. Wang Z, Chen X, Lu Y, Chen F, Zhang W. Clinical characteristics and therapeutic procedure for four cases with 2019 novel coronavirus pneumonia receiving combined Chinese and Western medicine treatment. Bioscience trends. 2020.

58. Wong PN, Mak SK, Lo KY, et al. Clinical presentation and outcome of severe acute respiratory syndrome in dialysis patients. American journal of kidney diseases : the official journal of the National Kidney Foundation. 2003;42(5):1075-1081.

59. Wu W, Wang J, Liu $P$, et al. A hospital outbreak of severe acute respiratory syndrome in Guangzhou, China. Chinese medical journal. 2003;116(6):811-818. 
medRxiv preprint doi: https://doi.org/10.1101/2020.03.19.20039008; this version posted March 25, 2020. The copyright holder for this preprint (which was not certified by peer review) is the author/funder, who has granted medRxiv a license to display the preprint in perpetuity.

It is made available under a CC-BY-NC-ND4.0 International license .

\section{APPENDIX 1 - Search Strategies}

\section{MEDLINE Search Strategy}

1 coronaviridae infections/ or coronavirus infections/ or severe acute respiratory syndrome/ or SARS Virus/

2 (coronavirus* or corona virus* or mers or middle east respiratory syndrome* or Severe Acute Respiratory Syndrome* or SARS or CoV or SARS-CoV or MERS-CoV or 2019nCoV).tw,kf.

3 or $/ 1-2$

4 dt.fs.

5 exp Antiviral Agents/

6 (antiviral or anti-viral or anti viral).tw,kf.

7 (neuraminidase adj2 inhibitor).tw,kf.

8 Remdesivir.tw,kf.

9 (oseltamivir or Tamiflu or peramivir or Rapivab or zanamivir or Relenza or ribavirin or lbavyr).tw,kf.

10 (matrix adj3 inhibitors).tw,kf.

11 exp DNA-Directed RNA Polymerases/

12 RNA polymerase inhibitors.tw,kf.

13 Rimantadine/

14 Rimantadine.tw,kf.

15 acyclic guanosine analogues.tw,kf.

16 Acyclovir/

17 Acyclovir.tw,kf.

18 acyclic nucleoside phosphonate analogues.tw,kf.

19 Cidofovir/

20 (diphosphate or Cidofovir).tw,kf.

21 Diphosphonates/

22 pyrophosphate analogues.tw,kf.

23 Foscarnet/

24 Foscarnet.tw,kf.

25 Oligonucleotides/

26 Fomivirsen.tw,kf.

27 Protease Inhibitors/

28 (boceprevir or telaprevir or lopinavir or ritonavir or darunavir or cobicistat or Prezcobix or indinavir or Crixivan or saquinavir or Invirase).tw,kf.

29 Integrase Inhibitors/

30 (raltegravir or elvitegravir or dolutegravir).tw,kf.

31 HIV Fusion Inhibitors/

32 (maraviroc or Celsentri).tw,kf.

33 Reverse Transcriptase Inhibitors/

34 nucleoside reverse transcriptase inhibitors.tw,kf.

35 (abacavir or Ziagen or emtricitabine or Emtriva or lamivudine or Epivir or tenofovir or Viread or zidovudine or azidothymidine or Retrovir).tw,kf.

36 nonnucleoside reverse transcriptase inhibitors.tw, kf.

37 (doravirine or Pifeltro or efavirenz or Sustiva or etravirine or Intelence or nevirapine or Viramune or rilpivirine or Edurant).tw,kf.

38 exp Interferon beta-1b/

39 (Betaseron or Extavia).tw,kf.

40 or/5-39 
medRxiv preprint doi: https://doi.org/10.1101/2020.03.19.20039008; this version posted March 25, 2020. The copyright holder for this preprint (which was not certified by peer review) is the author/funder, who has granted medRxiv a license to display the preprint in perpetuity.

It is made available under a CC-BY-NC-ND 4.0 International license .

41 Antineoplastic Agents, Immunological/

42 (abciximab or Reopro or adalimumab or Humira or Amjevita or alefacept or Amevive or alemtuzumab or Campath or basiliximab or Simulect or belimumab or Benlysta or bezlotoxumab or Zinplava or canakinumab or llaris or certolizumab or Cimzia or cetuximab or Erbitux or daclizumab or Zenapax or Zinbryta or denosumab or Prolia OR, Xgeva or efalizumab or Raptiva or golimumab or Simponi or inflectra or Remicade or ipilimumab or Yervoy or ixekizumab or Taltz or natalizumab or Tysabri or nivolumab or Opdivo or olaratumab or Lartruvo or omalizumab or Xolair or palivizumab or Synagis or panitumumab or Vectibix or pembrolizumab or Keytruda or rituximab or Rituxan or tocilizumab or Actemra or trastuzumab or Herceptin or secukinumab or Cosentyx or ustekinumab or Stelara).tw,kf.

43 exp Antibodies, Monoclonal/

44 or/41-43

45 medical countermeasures/

46 (countermeasure ${ }^{\star}$ or counter measure $\left.{ }^{\star}\right) . \mathrm{tw}, \mathrm{kf}$.

4745 or 46

484 or 40 or 44 or 47

$49 \quad 3$ and 48

50 animals/ not humans/

5149 not 50

Grey Literature: ClinicalTrials.gov and GIDEON (Global Infectious Diseases and Epidemiology Network).

Keyword search terms:

2019-nCoV

Coronavirus

CoV - note: this one may pick up an unrelated drug name: COV155

SARS

MERS

Middle East Respiratory Syndrome

Severe Acute Respiratory Syndrome 


\section{U) STW MIICHAELS}

\section{APPENDIX 2 - Potentially relevant articles not included in this review}

\begin{tabular}{|c|c|c|c|}
\hline First Author, Year & Title & Population & Article Type \\
\hline \multicolumn{4}{|c|}{ Literature Reviews, Meta-analysis, and Systematic Reviews } \\
\hline Gao, 2020 & Machine intelligence design of 2019-nCoV drugs & COVID-19 & Literature review \\
\hline Lu, 2020 & Drug treatment options for the 2019-new coronavirus (2019-nCoV) & COVID-19 & Literature review \\
\hline Arabi, 2016 & $\begin{array}{l}\text { The search for therapeutic options for Middle East Respiratory Syndrome } \\
\text { (MERS) }\end{array}$ & MERS & Literature review \\
\hline Behzadi, 2019 & $\begin{array}{l}\text { Overview of Current Therapeutics and Novel Candidates Against Influenza, } \\
\text { Respiratory Syncytial Virus, and Middle East Respiratory Syndrome } \\
\text { Coronavirus Infections }\end{array}$ & MERS & Literature review \\
\hline Chong, 2015 & Antiviral Treatment Guidelines for Middle East Respiratory Syndrome & MERS & Literature review \\
\hline Khan, 2018 & Middle east respiratory syndrome (MERS): A systematic review & MERS & $\begin{array}{l}\text { Systematic } \\
\text { review }\end{array}$ \\
\hline Lee, 2015 & $\begin{array}{l}\text { Current advances in the development of vaccines and therapeutic agents } \\
\text { against MERS-coV }\end{array}$ & MERS & Literature review \\
\hline Li, 2015 & $\begin{array}{l}\text { Clinical treatment and small molecular drugs for anti MERS-CoV: Research } \\
\text { advances }\end{array}$ & MERS & Literature review \\
\hline Malik, 2016 & $\begin{array}{l}\text { Middle east respiratory syndrome coronavirus: Current knowledge and future } \\
\text { considerations }\end{array}$ & MERS & Literature review \\
\hline Milne-Price, 2014 & The emergence of the Middle East Respiratory Syndrome coronavirus & MERS & Literature review \\
\hline Mo, 2016 & A review of treatment modalities for Middle East Respiratory Syndrome & MERS & Literature review \\
\hline Momattin, 2013 & $\begin{array}{l}\text { Therapeutic options for Middle East respiratory syndrome coronavirus } \\
\text { (MERS-CoV)--possible lessons from a systematic review of SARS-CoV } \\
\text { therapy }\end{array}$ & MERS & $\begin{array}{l}\text { Systematic } \\
\text { review }\end{array}$ \\
\hline Momattin, 2019 & $\begin{array}{l}\text { A Systematic Review of therapeutic agents for the treatment of the Middle } \\
\text { East Respiratory Syndrome Coronavirus (MERS-CoV) }\end{array}$ & MERS & $\begin{array}{l}\text { Systematic } \\
\text { review }\end{array}$ \\
\hline Morra, 2018 & $\begin{array}{l}\text { Clinical outcomes of current medical approaches for Middle East respiratory } \\
\text { syndrome: A systematic review and meta-analysis }\end{array}$ & MERS & $\begin{array}{l}\text { Systematic } \\
\text { review }\end{array}$ \\
\hline Van Le, 2017 & $\begin{array}{l}\text { Current medical treatment for middle east respiratory syndrome: A } \\
\text { systematic review }\end{array}$ & MERS & $\begin{array}{l}\text { Systematic } \\
\text { review }\end{array}$ \\
\hline
\end{tabular}




\begin{tabular}{|c|c|c|c|}
\hline First Author, Year & Title & Population & Article Type \\
\hline Zhou, 2019 & $\begin{array}{l}\text { Advances in MERS-CoV Vaccines and Therapeutics Based on the Receptor- } \\
\text { Binding Domain }\end{array}$ & MERS & Literature review \\
\hline Aronin, 2004 & Severe acute respiratory syndrome & SARS & Literature review \\
\hline Barnard, 2011 & $\begin{array}{l}\text { Recent developments in anti-severe acute respiratory syndrome coronavirus } \\
\text { chemotherapy }\end{array}$ & SARS & Literature review \\
\hline Berger, 2004 & $\begin{array}{l}\text { Severe acute respiratory syndrome (SARS)--paradigm of an emerging viral } \\
\text { infection }\end{array}$ & SARS & Literature review \\
\hline $\begin{array}{l}\text { Centre for } \\
\text { Reviews and } \\
\text { Dissemination, } \\
2015\end{array}$ & $\begin{array}{l}\text { Effect of integrated traditional Chinese medicine and Western medicine on } \\
\text { the treatment of severe acute respiratory syndrome: a meta-analysis } \\
\text { (Structured abstract) }\end{array}$ & SARS & Meta-analysis \\
\hline $\begin{array}{l}\text { Centre for } \\
\text { Reviews and } \\
\text { Dissemination, } \\
2015\end{array}$ & SARS: systematic review of treatment effects (Structured abstract) & SARS & $\begin{array}{l}\text { Systematic } \\
\text { review }\end{array}$ \\
\hline Chang, 2005 & $\begin{array}{l}\text { Clinical findings, treatment and prognosis in patients with severe acute } \\
\text { respiratory syndrome (SARS) }\end{array}$ & SARS & Literature review \\
\hline Cheng, 2004 & $\begin{array}{l}\text { Medical treatment of viral pneumonia including SARS in immunocompetent } \\
\text { adult }\end{array}$ & SARS & Literature review \\
\hline Cheng, 2007 & $\begin{array}{l}\text { Severe acute respiratory syndrome coronavirus as an agent of emerging and } \\
\text { reemerging infection }\end{array}$ & SARS & Literature review \\
\hline Cheng, 2013 & Clinical management and infection control of SARS: lessons learned & SARS & Literature review \\
\hline Cinatl, 2005 & Development of antiviral therapy for severe acute respiratory syndrome & SARS & Literature review \\
\hline Cleri, 2010 & Severe Acute Respiratory Syndrome (SARS) & SARS & Literature review \\
\hline Demmler, 2003 & $\begin{array}{l}\text { Severe acute respiratory syndrome (SARS): a review of the history, } \\
\text { epidemiology, prevention, and concerns for the future }\end{array}$ & SARS & Literature review \\
\hline File Jr, 2005 & $\begin{array}{l}\text { Severe acute respiratory syndrome: Pertinent clinical characteristics and } \\
\text { therapy }\end{array}$ & SARS & Literature review \\
\hline Fujii, 2004 & Current concepts in SARS treatment & SARS & Literature review \\
\hline Kawana, 2005 & Clinical and epidemiological review of SARS & SARS & $\begin{array}{l}\text { Literature } \\
\text { review }^{*}\end{array}$ \\
\hline Lai, 2004 & Clinical, Laboratory, and Radiologic Manifestation of SARS & SARS & Literature review \\
\hline
\end{tabular}




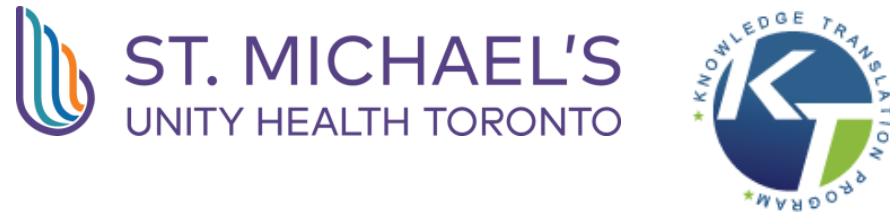

\begin{tabular}{|c|c|c|c|}
\hline First Author, Year & Title & Population & Article Type \\
\hline Lai, 2005 & Treatment of severe acute respiratory syndrome & SARS & Literature review \\
\hline Lapinsky, 2004 & Critical care lessons from severe acute respiratory syndrome & SARS & Literature review \\
\hline Liu, 2005 & $\begin{array}{l}\text { Systematic review and meta-analysis on the integrative traditional Chinese } \\
\text { and Western medicine in treating SARS }\end{array}$ & SARS & $\begin{array}{l}\text { Systematic } \\
\text { review* }\end{array}$ \\
\hline Liu, 2006 & $\begin{array}{l}\text { Chinese herbs combined with Western medicine for severe acute respiratory } \\
\text { syndrome (SARS) }\end{array}$ & SARS & $\begin{array}{l}\text { Systematic } \\
\text { review }\end{array}$ \\
\hline Mazzulli, 2004 & $\begin{array}{l}\text { Severe acute respiratory syndrome: overview with an emphasis on the } \\
\text { Toronto experience }\end{array}$ & SARS & Literature review \\
\hline Nassiri, 2003 & Severe acute respiratory syndrome & SARS & Literature review \\
\hline $\mathrm{Ng}, 2004$ & SARS in newborns and children & SARS & Literature review \\
\hline Nie, 2003 & Current status of severe acute respiratory syndrome in China & SARS & Literature review \\
\hline Oxford, 2005 & $\begin{array}{l}\text { New antiviral drugs, vaccines and classic public health interventions against } \\
\text { SARS coronavirus }\end{array}$ & SARS & Literature review \\
\hline Peetermans, 2004 & News viral respiratory infections & SARS & $\begin{array}{l}\text { Literature } \\
\text { review* }\end{array}$ \\
\hline Poutanen, 2004 & Severe acute respiratory syndrome: An update & SARS & Literature review \\
\hline Rainer, 2004 & $\begin{array}{l}\text { Severe acute respiratory syndrome: clinical features, diagnosis, and } \\
\text { management }\end{array}$ & SARS & Literature review \\
\hline Sheth, 2005 & Severe acute respiratory syndrome: Emergence of a new pandemic & SARS & Literature review \\
\hline Shuster, 2003 & $\begin{array}{l}\text { Preventing Adverse Drug Events with Rounding Pharmacists; Adverse Drug } \\
\text { Events Involving COX-2 Inhibitors; Psoriasis Associated with Rofecoxib; } \\
\text { Adverse Events Seen with Ribavirn Therapy for SARS; Immediate } \\
\text { Hypersensitivity to Clavulanic Acid; Thrombocytopenia with Vancomycin }\end{array}$ & SARS & Literature review \\
\hline Sirois, 2007 & Discovery of potent Anti-SARS-CoV $\mathrm{M}<$ sup $>$ Pro $</$ sup $>$ inhibitors & SARS & Literature review \\
\hline Stockman, 2006 & systematic review of treatment effects & SARS & $\begin{array}{l}\text { Systematic } \\
\text { review }\end{array}$ \\
\hline Tsang, 2004 & $\begin{array}{l}\text { Diagnosis and pharmacotherapy of severe acute respiratory syndrome: what } \\
\text { have we learnt? }\end{array}$ & SARS & Literature review \\
\hline $\begin{array}{l}\text { van Vonderen, } \\
2003\end{array}$ & Ribavirin in the treatment of severe acute respiratory syndrome (SARS) & SARS & Literature review \\
\hline Vijayanand, 2004 & Severe acute respiratory syndrome (SARS): a review & SARS & Literature review \\
\hline
\end{tabular}




\section{U) ST, MICHAELS}

\begin{tabular}{|c|c|c|c|}
\hline First Author, Year & Title & Population & Article Type \\
\hline Wong, 2003 & $\begin{array}{l}\text { Severe acute respiratory syndrome (SARS): Epidemiology, diagnosis and } \\
\text { management }\end{array}$ & SARS & Literature review \\
\hline Wong, 2008 & The management of coronavirus infections with particular reference to SARS & SARS & Literature review \\
\hline Wu, 2003 & Severe Acute Respiratory Syndrome (SARS) & SARS & $\begin{array}{l}\text { Literature } \\
\text { review* }\end{array}$ \\
\hline $\begin{array}{l}\text { Yazdanpanah, } \\
2006\end{array}$ & Antiretroviral drugs in severe acute respiratory syndrome & SARS & $\begin{array}{l}\text { Literature } \\
\text { review }\end{array}$ \\
\hline Zhang, 2004 & $\begin{array}{l}\text { Effect of integrated traditional Chinese and Western medicine on SARS: a } \\
\text { review of clinical evidence }\end{array}$ & SARS & $\begin{array}{l}\text { Systematic } \\
\text { review }\end{array}$ \\
\hline Zhaori, 2003 & Antiviral treatment of SARS: can we draw any conclusions? & SARS & Literature review \\
\hline Al-Hazmi, 2016 & $\begin{array}{l}\text { Challenges presented by MERS corona virus, and SARS corona virus to } \\
\text { global health }\end{array}$ & $\begin{array}{l}\text { SARS; } \\
\text { MERS }\end{array}$ & Literature review \\
\hline Gao, 2016 & From SARS to MERS: evidence and speculation & $\begin{array}{l}\text { SARS; } \\
\text { MERS }\end{array}$ & $\begin{array}{l}\text { Literature } \\
\text { review* }\end{array}$ \\
\hline Hilgenfeld, 2013 & $\begin{array}{l}\text { From SARS to MERS: } 10 \text { years of research on highly pathogenic human } \\
\text { coronaviruses }\end{array}$ & $\begin{array}{l}\text { SARS; } \\
\text { MERS }\end{array}$ & Literature review \\
\hline Blasi, 2003 & Winter and "atypical" respiratory infections. Italian & $\begin{array}{l}\text { General } \\
\text { coronavirus }\end{array}$ & $\begin{array}{l}\text { Literature } \\
\text { review }^{*}\end{array}$ \\
\hline Flight, 2017 & $\begin{array}{l}\text { The diagnosis and management of respiratory viral infections in cystic } \\
\text { fibrosis }\end{array}$ & $\begin{array}{l}\text { General } \\
\text { coronavirus }\end{array}$ & Literature review \\
\hline Luyt, 2011 & $\begin{array}{l}\text { Virus-induced acute respiratory distress syndrome: epidemiology, } \\
\text { management and outcome }\end{array}$ & $\begin{array}{l}\text { General } \\
\text { coronavirus }\end{array}$ & $\begin{array}{l}\text { Literature } \\
\text { review }^{*}\end{array}$ \\
\hline Pujanandez, 2017 & Antiviral gets the jump on coronaviruses & $\begin{array}{l}\text { General } \\
\text { Coronavirus }\end{array}$ & Literature review \\
\hline Steele, 1988 & Antiviral agents for respiratory infections & $\begin{array}{l}\text { General } \\
\text { Coronavirus }\end{array}$ & Literature review \\
\hline Tong, 2009 & Therapies for coronaviruses. Part 2: Inhibitors of intracellular life cycle & $\begin{array}{l}\text { General } \\
\text { coronavirus }\end{array}$ & Literature review \\
\hline Tong, 2009 & Therapies for coronaviruses. Part I of II -- viral entry inhibitors & $\begin{array}{l}\text { General } \\
\text { coronavirus }\end{array}$ & Literature review \\
\hline \multicolumn{4}{|c|}{ Trials Registrations and Protocols } \\
\hline Li, 2020 & A Randomized, Open-label, Controlled Study of the Efficacy of Lopinavir & COVID-19 & Trial registration \\
\hline
\end{tabular}




\begin{tabular}{|c|c|c|c|}
\hline First Author, Year & Title & Population & Article Type \\
\hline & $\begin{array}{l}\text { Plus Ritonavir and Arbidol for Treating With Patients With Novel Coronavirus } \\
\text { Infection [NCT04252885] }\end{array}$ & & \\
\hline Lu, 2020 & $\begin{array}{l}\text { Efficacy and Safety of Darunavir and Cobicistat for Treatment of Pneumonia } \\
\text { Caused by 2019-nCoV [NCT04252274] }\end{array}$ & COVID-19 & Trial registration \\
\hline Qiu, 2020 & $\begin{array}{l}\text { A Randomized, Open-label, Multi-centre Clinical Trial Evaluating and } \\
\text { Comparing the Safety and Efficiency of ASC09/Ritonavir and } \\
\text { Lopinavir/Ritonavir for Confirmed Cases of Pneumonia Caused by Novel } \\
\text { Coronavirus Infection [NCT04261907] }\end{array}$ & COVID-19 & Trial registration \\
\hline Xiao, 2020 & $\begin{array}{l}\text { Effects of Traditional Chinese Medicines (TCMs) on Patients With 2019- } \\
\text { nCoV Infection: A Perspective, Open-labeled, Randomized, Controlled Trial } \\
\text { [NCT04251871] }\end{array}$ & COVID-19 & Trial registration \\
\hline Arabi, 2016 & $\begin{array}{l}\text { MERS-CoV Infection tReated With A Combination of Lopinavir /Ritonavir and } \\
\text { Interferon Beta-1b: a Multicenter, Placebo-controlled, Double-blind } \\
\text { Randomized Trial [NCT02845843] }\end{array}$ & MERS & Trial registration \\
\hline Arabi, 2018 & $\begin{array}{l}\text { Treatment of Middle East Respiratory Syndrome with a combination of } \\
\text { lopinavir-ritonavir and interferon-beta1b (MIRACLE trial): study protocol for a } \\
\text { randomized controlled trial }\end{array}$ & MERS & Protocol \\
\hline Arabi, 2020 & $\begin{array}{l}\text { Treatment of Middle East respiratory syndrome with a combination of } \\
\text { lopinavir/ritonavir and interferon-beta1b (MIRACLE trial): statistical analysis } \\
\text { plan for a recursive two-stage group sequential randomized controlled trial }\end{array}$ & MERS & Protocol \\
\hline Davey, 2016 & $\begin{array}{l}\text { A Phase 1, Randomized Double-Blind, Placebo-Controlled, Single Ascending } \\
\text { Dose Safety, Tolerability, and Pharmacokinetics Study of SAB-301 in } \\
\text { Healthy Adults [NCT02788188] }\end{array}$ & MERS & Trial registration \\
\hline $\begin{array}{l}\text { National Institute } \\
\text { of Allergy and } \\
\text { Infectious } \\
\text { Diseases (NIAID), } \\
2017 \\
\end{array}$ & $\begin{array}{l}\text { A Phase I Trial to Evaluate the Safety, Tolerability, Pharmacokinetics and } \\
\text { Immunogenicity of Co-administered MERS-CoV Antibodies REGN3048 and } \\
\text { REGN3051 vs. Placebo in Healthy Adults [NCT03301090] }\end{array}$ & MERS & Trial registration \\
\hline Tong, 2005 & $\begin{array}{l}\text { A Randomized, Dose-ranging Study of Alferon } \AA \text { LDO ] Low Dose Oral } \\
\text { Interferon Alfa-n3 (Human Leukocyte Derived)] in Normal Volunteers and/or } \\
\text { Asymptomatic Subjects With Exposure to a Person Known to Have SARS or } \\
\text { Possible SARS [NCT00215826] }\end{array}$ & SARS & Trial registration \\
\hline
\end{tabular}




\section{U) ST, MICHAELS}

\begin{tabular}{|c|c|c|c|}
\hline First Author, Year & Title & Population & Article Type \\
\hline Yu, 2007 & $\begin{array}{l}\text { A Multi-centre, Double-blinded, Randomized, Placebo-controlled Trial on the } \\
\text { Efficacy and Safety of Lopinavir / Ritonavir Plus Ribavirin in the Treatment of } \\
\text { Severe Acute Respiratory Syndrome [NCT00578825] }\end{array}$ & SARS & Trial registration \\
\hline Yu, 2008 & $\begin{array}{l}\text { A protocol for a multi-centre, double blinded, randomised, placebo-controlled } \\
\text { trial on the efficacy and safety of lopinavir/ritonavir plus ribavirin in the } \\
\text { treatment of severe acute respiratory syndrome }\end{array}$ & SARS & Protocol \\
\hline \multicolumn{4}{|c|}{ Full-text Unavailable and Non-English Articles } \\
\hline Albarrak, 2012 & Recovery from severe novel coronavirus infection & MERS & Unavailable \\
\hline Khalid, 2015 & $\begin{array}{l}\text { Ribavirin and interferon-alpha2b as primary and preventive treatment for } \\
\text { Middle East respiratory syndrome coronavirus: a preliminary report of two } \\
\text { cases }\end{array}$ & MERS & Unavailable \\
\hline Kim, 2016 & $\begin{array}{l}\text { Combination therapy with lopinavir/ritonavir, ribavirin and interferon-alpha for } \\
\text { Middle East respiratory syndrome }\end{array}$ & MERS & Unavailable \\
\hline Ling, 2015 & $\begin{array}{l}\text { Clinical analysis of the first patient with imported Middle East respiratory } \\
\text { syndrome in China }\end{array}$ & MERS & $\begin{array}{l}\text { Unavailable/Non- } \\
\text { English }\end{array}$ \\
\hline Luo, 2015 & $\begin{array}{l}\text { The therapeutic effect of high flow nasal cannula oxygen therapy for the first } \\
\text { imported case of Middle East respiratory syndrome to China }\end{array}$ & MERS & $\begin{array}{l}\text { Unavailable/Non- } \\
\text { English }\end{array}$ \\
\hline Nau, 2013 & Emergency treatment for Middle Eastern coronaviruses (MERS-CoV) & MERS & Non-English \\
\hline Cao, 2003 & Clinical diagnosis, treatment and prognosis of elderly SARS patients & SARS & $\begin{array}{l}\text { Unavailable/Non- } \\
\text { English }\end{array}$ \\
\hline Chan, 2004 & $\begin{array}{l}\text { Clinical manifestations of two cases with severe acute respiratory syndrome } \\
\text { (SARS) in I-Lan County }\end{array}$ & SARS & Unavailable \\
\hline Feldt, 2003 & SARS--the facts. Transmission, diagnosis and managing suspected cases & SARS & $\begin{array}{l}\text { Unavailable/Non- } \\
\text { English }\end{array}$ \\
\hline Fu, 2003 & $\begin{array}{l}\text { Analysis of therapeutic effect on treatment of SARS by Chinese Medicine in } \\
\text { combination with Western Medicine of } 253 \text { cases }\end{array}$ & SARS & Non-English \\
\hline Gao, 2003 & $\begin{array}{l}\text { Clinical investigation of outbreak of nosocomial severe acute respiratory } \\
\text { syndrome }\end{array}$ & SARS & $\begin{array}{l}\text { Unavailable/Non- } \\
\text { English }\end{array}$ \\
\hline Hoheisel, 2003 & Severe acute respiratory syndrome (SARS) & SARS & Non-English \\
\hline Hou, 2004 & $\begin{array}{l}\text { Integrated traditional Chinese and western medicine for } 34 \text { patients with } \\
\text { severe SARS }\end{array}$ & SARS & Unavailable \\
\hline Hsiao, 2004 & Clinicopathology of severe acute respiratory syndrome: an autopsy case & SARS & Unavailable \\
\hline
\end{tabular}




\section{UL ST. MICHAEL'S \\ UNITY HEALTH TORONTO}

\begin{tabular}{|c|c|c|c|}
\hline First Author, Year & Title & Population & Article Type \\
\hline & report & & \\
\hline Huang, 2004 & $\begin{array}{l}\text { Clinical observation on curative effect of treating SARS with the combination } \\
\text { of traditional Chinese and Western therapy }\end{array}$ & SARS & Unavailable \\
\hline Kanra, 2003 & Severe acute respiratory syndrome (SARS) & SARS & $\begin{array}{l}\text { Unavailable/Non- } \\
\text { English }\end{array}$ \\
\hline Li, 2003 & $\begin{array}{l}\text { Changes of liver function in } 48 \text { patients with SARS and treatment of } \\
\text { integrative traditional Chinese and Western medicine }\end{array}$ & SARS & Unavailable \\
\hline Li, 2003 & Clinical features of 77 patients with severe acute respiratory syndrome & SARS & $\begin{array}{l}\text { Unavailable/Non- } \\
\text { English }\end{array}$ \\
\hline Li, 2003 & $\begin{array}{l}\text { Clinical observation of } 40 \text { cases of SARS in the restoration stage treated by } \\
\text { an integrated therapy of tcm and western medicine }\end{array}$ & SARS & Unavailable \\
\hline Li, 2004 & $\begin{array}{l}\text { Clinical study on treatment of severe acute respiratory syndrome with } \\
\text { integrative Chinese and Western medicine approach }\end{array}$ & SARS & $\begin{array}{l}\text { Unavailable/Non- } \\
\text { English }\end{array}$ \\
\hline Liu, 2003 & $\begin{array}{l}\text { Clinical features and therapy of } 106 \text { cases of severe acute respiratory } \\
\text { syndrome }\end{array}$ & SARS & Non-English \\
\hline Liu, 2003 & $\begin{array}{l}\text { Quality of randomized controlled trials of traditional Chinese medicine } \\
\text { integrated with Western medicine for severe acute respiratory syndrome }\end{array}$ & SARS & Unavailable \\
\hline Lin, 2003 & $\begin{array}{l}\text { Clinical observation on } 103 \text { patients of severe acute respiratory syndrome } \\
\text { treated by integrative traditional Chinese and Western Medicine }\end{array}$ & SARS & $\begin{array}{l}\text { Unavailable/Non- } \\
\text { English }\end{array}$ \\
\hline MacKay, 2005 & $\begin{array}{l}\text { Adverse drug reactions associated with the use of ribavirin in the treatment } \\
\text { of severe acute respiratory syndrome (SARS) }\end{array}$ & SARS & Unavailable \\
\hline Marraro, 2003 & Severe Acute Respiratory Syndrome (SARS) & SARS & $\begin{array}{l}\text { Unavailable/Non- } \\
\text { English }\end{array}$ \\
\hline Ren, 2004 & $\begin{array}{l}\text { Clinical study on treatment of severe acute respiratory syndrome by } \\
\text { integrative Chinese and Western medicine }\end{array}$ & SARS & $\begin{array}{l}\text { Unavailable/Non- } \\
\text { English }\end{array}$ \\
\hline Rickerts, 2003 & $\begin{array}{l}\text { [Clinical presentation and management of the severe acute respiratory } \\
\text { syndrome (SARS)] }\end{array}$ & SARS & Non-English \\
\hline Shi, 2010 & $\begin{array}{l}\text { Study on the changing regularity of special antibody and expression of } \\
\text { stomach and enteric involvement on SARS-coronavirus infection in the } \\
\text { recovery period of severe acute respiratory syndrome }\end{array}$ & SARS & $\begin{array}{l}\text { Unavailable/Non- } \\
\text { English }\end{array}$ \\
\hline Tan, 2003 & $\begin{array}{l}\text { Radiographic features of a case of severe acute respiratory syndrome with } \\
\text { fatal outcome }\end{array}$ & SARS & Unavailable \\
\hline
\end{tabular}




\section{US ST MICHAELS}

\begin{tabular}{|c|c|c|c|}
\hline First Author, Year & Title & Population & Article Type \\
\hline Wang, 2003 & $\begin{array}{l}\text { Preliminary study on clinical efficacy of integrative Chinese and western } \\
\text { medicine in treating severe acute respiratory syndrome (SARS) }\end{array}$ & SARS & $\begin{array}{l}\text { Unavailable/Non- } \\
\text { English }\end{array}$ \\
\hline Wu, 2003 & $\begin{array}{l}\text { Clinical observation on treatment of } 40 \text { SARS uncertain patients with } \\
\text { integrative traditional Chinese and Western medicine }\end{array}$ & SARS & Non-English \\
\hline Wu, 2004 & $\begin{array}{l}\text { Comparison of clinical features of severe acute respiratory syndrome among } \\
\text { different transmission generations }\end{array}$ & SARS & $\begin{array}{l}\text { Unavailable/Non- } \\
\text { English }\end{array}$ \\
\hline Xu, 2003 & $\begin{array}{l}\text { Clinical therapy of severe acute respiratory syndrome: } 38 \text { cases } \\
\text { retrospective analysis }\end{array}$ & SARS & $\begin{array}{l}\text { Unavailable/Non- } \\
\text { English }\end{array}$ \\
\hline Xu, 2003 & $\begin{array}{l}\text { Clinical analysis of patients with severe acute respiratory syndrome in Beijing } \\
\text { area }\end{array}$ & SARS & $\begin{array}{l}\text { Unavailable/Non- } \\
\text { English }\end{array}$ \\
\hline Zhang, 2003 & $\begin{array}{l}\text { Clinical observation of } 65 \text { SARS cases treated with a combination of TCM } \\
\text { and western-style therapies }\end{array}$ & SARS & Unavailable \\
\hline Zhang, 2003 & $\begin{array}{l}\text { Controlled clinical study on } 49 \text { patients of SARS treated by integrative } \\
\text { Chinese and Western medicine }\end{array}$ & SARS & $\begin{array}{l}\text { Unavailable/Non- } \\
\text { English }\end{array}$ \\
\hline Zhang, 2004 & $\begin{array}{l}\text { Clinical study of integrated Chinese and western medicien for quality of life } \\
\text { improvements of SARS patients on recovery stage }\end{array}$ & SARS & Unavailable \\
\hline Zhao, 2003 & $\begin{array}{l}\text { Randomized control study of integrated traditional Chinese and western } \\
\text { medicine in treatment of } 77 \text { patients with severe acute respiratory syndrome }\end{array}$ & SARS & Unavailable \\
\hline Zhou, 2003 & $\begin{array}{l}\text { [Epidemiologic features, clinical diagnosis and therapy of first cluster of } \\
\text { patients with severe acute respiratory syndrome in Beijing area] }\end{array}$ & SARS & Non-English \\
\hline Vabret, 2005 & Human coronaroviruses & $\begin{array}{l}\text { General } \\
\text { coronavirus }\end{array}$ & Non-English \\
\hline
\end{tabular}

${ }^{*}$ Non-English articles 


\section{U) STIMAMHAEL'S}

\section{APPENDIX 3 - Detailed Table of Study and Patient Characteristics}

\begin{tabular}{|c|c|c|c|c|}
\hline $\begin{array}{l}\text { Author, Year; } \\
\text { Country of } \\
\text { Conduct }\end{array}$ & Study Period, Setting & $\begin{array}{c}\text { Diagnosis, } \\
\text { Diagnostic Criteria }\end{array}$ & $\begin{array}{l}\text { Age (variance), } \\
\text { Sample Size, } \\
\% \text { Female, \% Male }\end{array}$ & Co-morbidities \\
\hline \multicolumn{5}{|c|}{ Controlled Trials $n=3$} \\
\hline $\begin{array}{l}\text { Lee, } 2004^{6} \\
\text { China }\end{array}$ & $\begin{array}{l}\text { Apr } 2003 \text { to May } 2003 \text {, } \\
\text { Hong Kong }\end{array}$ & $\begin{array}{l}\text { SARS, } \\
\text { Lab-confirmed }\end{array}$ & $\begin{array}{l}\text { Median (range): } 34(22- \\
57), \\
\mathrm{N}=16, \\
\text { Females: NR, Males: NR }\end{array}$ & None reported \\
\hline $\begin{array}{l}\text { Zhao, } \mathbf{2 0 0 3}^{\mathbf{8}} \\
\text { China }\end{array}$ & $\begin{array}{l}\text { NR, } \\
\text { Eighth Municipal } \\
\text { People's Hospital of } \\
\text { Guangzhou; Second } \\
\text { and Third Affiliated } \\
\text { Hospitals of Sun Yet- } \\
\text { San Medical University }\end{array}$ & $\begin{array}{l}\text { SARS, } \\
\text { Probable/suspected }\end{array}$ & $\begin{array}{l}\text { Group A [mean (SD)]: } 33.6 \\
(13.9) \\
\text { Group B: } 32.4(12.4) \\
\text { Group C: } 32.5(12.1) \\
\text { Group D: } 30.5(12.3) \\
\text { N=190, } \\
\text { Females: } 65 \text {, Males: } 35\end{array}$ & None reported \\
\hline $\begin{array}{l}\text { Park, 20197 } \\
\text { South Korea }\end{array}$ & $\begin{array}{l}\text { NR, } \\
5 \text { hospitals of South } \\
\text { Korea }\end{array}$ & $\begin{array}{l}\text { Prophylaxis (MERS), } \\
\text { Lab-confirmed }\end{array}$ & $\begin{array}{l}\text { Median (IQR): } 29(24-33) \\
\mathrm{N}=43, \\
\text { Females: } 65.1, \text { Males: NR }\end{array}$ & None reported \\
\hline \multicolumn{5}{|c|}{ Cohort Studies $n=10$} \\
\hline $\begin{array}{l}\text { Chan, 2003'1 } \\
\text { Hong Kong }\end{array}$ & $\begin{array}{l}\text { NR, } \\
\text { United Christian } \\
\text { Hospital, Princess } \\
\text { Margaret Hospital, } \\
\text { Tuen Mun Hospital, } \\
\text { and Caritas Medical } \\
\text { Centre }\end{array}$ & $\begin{array}{l}\text { SARS, } \\
\text { Lab-confirmed }\end{array}$ & $\begin{array}{l}\mathrm{NR}(\mathrm{NR}) \\
\mathrm{N}=1052, \\
\text { Females: } 81 \text {, Males: } 19\end{array}$ & None reported \\
\hline $\begin{array}{l}\text { Chu, 2004 } \\
\text { Hong Kong }\end{array}$ & $\begin{array}{l}\text { Mar to Apr } 2003 \\
\text { (recruitment); } \\
21 \text { day follow-up, } \\
\text { United Christian } \\
\text { Hospital and Caritas } \\
\text { Medical Centre }\end{array}$ & $\begin{array}{l}\text { SARS, } \\
\text { WHO Criteria } \\
\text { (admission); } 97.6 \% \text { of } \\
\text { cases lab-confirmed }\end{array}$ & $\begin{array}{l}\text { Mean (SD): } 41.4(14.8), \\
N=152 \\
\text { Females: } 62 \text {, Males: } 38\end{array}$ & $\begin{array}{l}\text { Active co-morbid condition, chronic } \\
\text { hepatitis } b \text { infection }\end{array}$ \\
\hline
\end{tabular}




\begin{tabular}{|c|c|c|c|c|}
\hline $\begin{array}{l}\text { Author, Year; } \\
\text { Country of } \\
\text { Conduct }\end{array}$ & Study Period, Setting & $\begin{array}{l}\text { Diagnosis, } \\
\text { Diagnostic Criteria }\end{array}$ & $\begin{array}{l}\text { Age (variance), } \\
\text { Sample Size, } \\
\% \text { Female, \% Male }\end{array}$ & Co-morbidities \\
\hline $\begin{array}{l}\text { Guo, 201914 } \\
\text { China }\end{array}$ & $\begin{array}{l}12 \text { year follow-up, } \\
\text { Guangdong Provincial } \\
\text { Hospital }\end{array}$ & $\begin{array}{l}\text { SARS, } \\
\text { Lab-confirmed }\end{array}$ & $\begin{array}{l}\text { Median (IQR): } 33(24-57), \\
\mathrm{N}=103 \text {, } \\
\text { Females:57, Males: } 42.7\end{array}$ & $\begin{array}{l}\text { Ischaemic heart disease, Pulmonary, } \\
\text { Diabetes, Malignancy, } \\
\text { Immunocompromising condition }\end{array}$ \\
\hline $\begin{array}{l}\text { Ho, } 2003^{15} \\
\text { Hong Kong }\end{array}$ & $\begin{array}{l}\text { Mar to Apr 2003, } \\
\text { Queen Mary and } \\
\text { Queen Elizabeth } \\
\text { Hospitals }\end{array}$ & $\begin{array}{l}\text { SARS, } \\
\text { WHO Criteria } \\
\text { (admission); 69/72 lab- } \\
\text { confirmed }\end{array}$ & $\begin{array}{l}\text { Median (IQR): } 37(23-82), \\
\mathrm{N}=72 \\
\text { Females: } 58, \text { Males: } 42\end{array}$ & $\begin{array}{l}\text { Ischemic heart disease, malignancy, } \\
\text { diabetes mellitus, other-unspecified }\end{array}$ \\
\hline $\begin{array}{l}\text { Lau, 2009'16 } \\
\text { China and } \\
\text { Canada }\end{array}$ & $\begin{array}{l}\text { NR, Hong Kong and } \\
\text { Toronto }\end{array}$ & $\begin{array}{l}\text { SARS, } \\
\text { WHO Criteria; } \\
\text { Probable/suspected }\end{array}$ & $\begin{array}{l}\text { NR (NR), } \\
\mathrm{N}=1743 \text { (probable); } 191 \\
\text { (suspected), } \\
\text { Females: } 56 ; 61 \text {, Males: } \\
44 ; 39\end{array}$ & None reported \\
\hline $\begin{array}{l}\text { Leong, } 2004^{17} \\
\text { Singapore }\end{array}$ & $\begin{array}{l}\text { Mar to Aug 2003, } \\
\text { Tan Tock Seng } \\
\text { Hospital }\end{array}$ & $\begin{array}{l}\text { SARS, } \\
\text { WHO Criteria } \\
\text { (admission); } \\
32 \text { cases lab-confirmed }\end{array}$ & $\begin{array}{l}\text { Non-ribavirin [mean (SD)]: } \\
42.6 \text { (17.7) } \\
\text { Ribavirin: } 34.4 \text { (14.3), } \\
\mathrm{N}=229 \text {, } \\
\text { Females: NR, Males: } 32\end{array}$ & None reported \\
\hline $\begin{array}{l}\text { Li, } 2006^{18} \\
\text { China }\end{array}$ & $\begin{array}{l}\text { Cohort, Apr to May } \\
\text { 2003, } \\
\text { First Affiliated Hospital, } \\
\text { Tsinghua University }\end{array}$ & $\begin{array}{l}\text { SARS, } \\
\text { WHO Criteria }\end{array}$ & $\begin{array}{l}\text { Mean (range): } 36(15-73) \\
N=123, \\
\text { Females: } 50.4 \text {, Males: } 49.6\end{array}$ & $\begin{array}{l}\text { Hypertension, chronic obstructive } \\
\text { pulmonary disease (COPD) and asthma, } \\
\text { diabetes mellitus, and cerebrovascular } \\
\text { diseases }\end{array}$ \\
\hline $\begin{array}{l}\text { Alkhadhairi, } \\
2018^{9} \\
\text { Saudi Arabia }\end{array}$ & $\begin{array}{l}\text { Sep } 2013 \text { to Jun } 2017 \text {, } \\
\text { Hospital (unspecified) }\end{array}$ & $\begin{array}{l}\text { MERS, } \\
\text { Lab-confirmed }\end{array}$ & $\begin{array}{l}\text { NR (NR), } \\
\mathrm{N}=113, \\
\text { Females: NR, Males: NR }\end{array}$ & None reported \\
\hline $\begin{array}{l}\text { Arabi, } 2019^{10} \\
\text { Saudi Arabia }\end{array}$ & $\begin{array}{l}\text { Sep } 2010 \text { to Jan } 2018 \text {, } \\
14 \text { hospitals in } 5 \text { cities }\end{array}$ & $\begin{array}{l}\text { MERS, } \\
\text { Lab-confirmed }\end{array}$ & $\begin{array}{l}\text { Treatment [median, (IQR)]: } \\
57.5(47-70) \\
\text { Control: } 58(41-70) \\
\text { N = 349, } \\
\text { Females: NR, Males: } 69\end{array}$ & $\begin{array}{l}\text { Diabetes with chronic complications; } \\
\text { asthma/chronic pulmonary disease; } \\
\text { moderate to severe liver disease; chronic } \\
\text { renal disease; chronic cardiac disease; } \\
\text { chronic neurological disease; } \\
\text { rheumatological disease; malignancy } \\
\text { including leukemia or lymphoma }\end{array}$ \\
\hline
\end{tabular}




\section{(L) ST. MICHAEL'S}

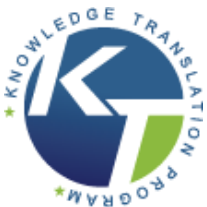

\begin{tabular}{|c|c|c|c|c|}
\hline $\begin{array}{l}\text { Author, Year; } \\
\text { Country of } \\
\text { Conduct }\end{array}$ & Study Period, Setting & $\begin{array}{l}\text { Diagnosis, } \\
\text { Diagnostic Criteria }\end{array}$ & $\begin{array}{l}\text { Age (variance), } \\
\text { Sample Size, } \\
\% \text { Female, \% Male }\end{array}$ & Co-morbidities \\
\hline $\begin{array}{l}\text { Choi, } 2016^{12} \\
\text { Republic of } \\
\text { Korea }\end{array}$ & $\begin{array}{l}\text { May to July } 2015, \\
\text { Republic of Korea }\end{array}$ & $\begin{array}{l}\text { MERS, } \\
\text { Lab-confirmed }\end{array}$ & $\begin{array}{l}\text { Median (range): } 55(16- \\
86) \text {, } \\
\mathrm{N}=186 \text {, } \\
\text { Females: NR, Males: } 60\end{array}$ & $\begin{array}{l}\text { Hypertension, Diabetes, Solid organ } \\
\text { malignancy, Chronic lung disease, Chronic } \\
\text { heart disease, Cerebrovascular disease, } \\
\text { Chronic liver disease, Chronic kidney } \\
\text { disease, Hematologic malignancy }\end{array}$ \\
\hline \multicolumn{5}{|c|}{ Retrospective Studies $n=7$} \\
\hline $\begin{array}{l}\text { Booth, } 2003^{20} \\
\text { Canada }\end{array}$ & $\begin{array}{l}\text { March to April 2003, } \\
\text { Hospitals in Toronto }\end{array}$ & $\begin{array}{l}\text { SARS, } \\
\text { Probable/suspected }\end{array}$ & $\begin{array}{l}\text { Median (range): } 45 \text { (34 to } \\
57) \\
\mathrm{N}=144 \\
\text { Females: } 61 \% \text {, Males: NR }\end{array}$ & $\begin{array}{l}\text { Diabetes, cardiac disease, cancer, COPD, } \\
\text { chronic renal failure }\end{array}$ \\
\hline $\begin{array}{l}\text { Chiou, } 2005^{21} \\
\text { Taiwan }\end{array}$ & $\begin{array}{l}\text { April to June } 2003 \text {, } \\
\text { Mackay Memorial } \\
\text { Hospital and Chang } \\
\text { Gung Memorial } \\
\text { Hospital }\end{array}$ & $\begin{array}{l}\text { SARS, } \\
\text { Lab-confirmed }\end{array}$ & $\begin{array}{l}\text { Mean (SD): } 38(17.5) \\
N=51 \\
\text { Females: } 74 \% \text {, Males: } \\
26 \%\end{array}$ & None reported \\
\hline $\begin{array}{l}\text { Liu, } 2005^{24} \\
\text { Taiwan }\end{array}$ & $\begin{array}{l}\text { April to May 2003, } \\
\text { The Armed Forces } \\
\text { Sung-Shan Hospital }\end{array}$ & $\begin{array}{l}\text { SARS, } \\
\text { WHO Criteria }\end{array}$ & $\begin{array}{l}\text { Median (range): } 37(22-66) \\
\mathrm{N}=36 \\
\text { Females: } 75 \% \text {, Males: } \\
25 \%\end{array}$ & $\begin{array}{l}\text { Diabetes mellitus, cardiovascular disease, } \\
\text { ovarian teratoma, hydronephrosis, thyroid } \\
\text { disease, diabetes plus gallstones }\end{array}$ \\
\hline $\begin{array}{l}\text { Muller, } 2007^{25} \\
\text { Canada }\end{array}$ & $\begin{array}{l}\text { February to July } 2003, \\
\text { Hospitals in Toronto }\end{array}$ & $\begin{array}{l}\text { SARS, } \\
\text { WHO Criteria with lab } \\
\text { confirmation }\end{array}$ & $\begin{array}{l}\mathrm{NR} \\
\mathrm{N}=306 \\
\text { Females: } 63 \% \text {, Males: } \\
37 \%\end{array}$ & None reported \\
\hline $\begin{array}{l}\text { Alhumaid, } \\
2018^{19} \\
\text { Saudi Arabia }\end{array}$ & $\begin{array}{l}\text { April } 2012 \text { to } \\
\text { November } 2016 \text {, } \\
\text { King Fahad Hofuf } \\
\text { Hospital }\end{array}$ & $\begin{array}{l}\text { MERS, } \\
\text { Contact history (animal); } \\
\text { Lab-confirmed }\end{array}$ & $\begin{array}{l}\mathrm{NR}, \\
\mathrm{N}=107 \\
\text { Females: NR, Males: } \\
69.1 \%\end{array}$ & $\begin{array}{l}\text { Chronic kidney disease, chronic heart } \\
\text { disease, chronic lung disease, liver } \\
\text { disease, diabetes, hypertension, } \\
\text { malignancy, obesity, immunosuppressive } \\
\text { therapies use, Immunocompromised } \\
\text { status, organ transplant, pregnancy }\end{array}$ \\
\hline $\begin{array}{l}\text { Habib, } 2019^{22} \\
\text { Saudi Arabia }\end{array}$ & $\begin{array}{l}2014 \text { to } 2017, \\
\text { Buraidah Central } \\
\text { Hospital }\end{array}$ & $\begin{array}{l}\text { MERS, } \\
\text { Lab-confirmed }\end{array}$ & $\begin{array}{l}\text { Mean (SD): } 59.7(18.2) \\
N=63 \\
\text { Females: } 25 \% \text {, Males: } \\
75 \%\end{array}$ & $\begin{array}{l}\text { Diabetes, hypertension, hepatitis } \mathrm{C} \text {, } \\
\text { chronic renal diseases, and chronic heart } \\
\text { diseases }\end{array}$ \\
\hline
\end{tabular}




\section{(L) ST. MICHAEL'S}

\begin{tabular}{|c|c|c|c|c|}
\hline $\begin{array}{l}\text { Author, Year; } \\
\text { Country of } \\
\text { Conduct }\end{array}$ & Study Period, Setting & $\begin{array}{c}\text { Diagnosis, } \\
\text { Diagnostic Criteria }\end{array}$ & $\begin{array}{l}\text { Age (variance), } \\
\text { Sample Size, } \\
\% \text { Female, \% Male }\end{array}$ & Co-morbidities \\
\hline $\begin{array}{l}\text { Khalid, } 2016^{23} \\
\text { Saudi Arabia }\end{array}$ & $\begin{array}{l}\text { April to May } 2014, \\
\text { King Faisal Specialist } \\
\text { Hospital and Research } \\
\text { Center }\end{array}$ & $\begin{array}{l}\text { MERS, } \\
\text { Lab-confirmed }\end{array}$ & $\begin{array}{l}\text { Median (IQR): } 54(23-79) \\
\mathrm{N}=14, \\
\text { Females: } 36 \% \text {, Males: } \\
64 \%\end{array}$ & $\begin{array}{l}\text { Hypertension, diabetes, respiratory } \\
\text { disease, obesity, congestive heart failure, } \\
\text { chronic kidney disease (no dialysis), } \\
\text { hemodialysis, ischemic heart disease, } \\
\text { receiving immunosuppressive medications, } \\
\text { stroke }\end{array}$ \\
\hline \multicolumn{5}{|c|}{ Case Reports/Series $n=34$} \\
\hline $\begin{array}{l}\text { Holshue, } 2020^{35} \\
\text { USA }\end{array}$ & $\begin{array}{l}\text { January } 1,2020, \\
\text { Providence Regional } \\
\text { Medical Center }\end{array}$ & $\begin{array}{l}\text { COVID-19, Lab- } \\
\text { confirmed }\end{array}$ & $\begin{array}{l}\text { Age: } 35 \\
N=1 \\
\text { Females: } 0 \text {, Males: } 100\end{array}$ & Hypertriglyceridemia \\
\hline $\begin{array}{l}\text { Wang, 2020a } \\
\text { China }\end{array}$ & $\begin{array}{l}\text { Jan } 21 \text { to Feb } 4,2020 \text {, } \\
\text { Shanghai Public } \\
\text { Health Clinical Center }\end{array}$ & $\begin{array}{l}\text { COVID-19, Lab- } \\
\text { confirmed }\end{array}$ & $\begin{array}{l}\text { Ages: } 19,32,62,63 \\
N=4 \\
\text { Females: } 25, \text { Males: } 75\end{array}$ & Fatty liver \\
\hline $\begin{array}{l}\text { Wang, 2020b } 56 \\
\text { China }\end{array}$ & $\begin{array}{l}\text { Jan } 1 \text { to Feb } 3,2020 \\
\text { Zhongnan Hospital of } \\
\text { Wuhan University }\end{array}$ & $\begin{array}{l}\text { COVID-19, WHO } \\
\text { Criteria (admission); } \\
\text { lab-confirmed }\end{array}$ & $\begin{array}{l}\text { Median (range): } 56(42-68) \\
\mathrm{N}=138 \\
\text { Females: } 45.7, \text { Males: } 54.3\end{array}$ & $\begin{array}{l}\text { Hypertension; cardiovascular disease; } \\
\text { diabetes; malignancy; cerebrovascular } \\
\text { disease; COPD; chronic kidney disease; } \\
\text { chronic liver disease; HIV infection }\end{array}$ \\
\hline $\begin{array}{l}\text { Avendano, } \\
\mathbf{2 0 0 3 ^ { 2 8 }} \\
\text { Canada }\end{array}$ & $\begin{array}{l}\text { March 23, } 2003 \text { (3 } \\
\text { weeks), } \\
\text { West Park Healthcare } \\
\text { Centre }\end{array}$ & SARS, WHO Criteria & $\begin{array}{l}\text { Mean (SD, range): } 42(9, \\
27-63) \\
N=14 \\
\text { Females: } 78.57, \text { Males: } \\
21.43\end{array}$ & $\begin{array}{l}\text { Mitral valve prolapse, type } 2 \text { diabetes } \\
\text { mellitus, hypertension, cancer of the } \\
\text { bladder, osteoporosis }\end{array}$ \\
\hline $\begin{array}{l}\text { Cheng, 2004 } \\
\text { China }\end{array}$ & $\begin{array}{l}\text { March } 2003 \text { - May } \\
2003 \text {, } \\
\text { Prince of Wales } \\
\text { Hospital }\end{array}$ & SARS, WHO Criteria & $\begin{array}{l}\text { Median (range): } 11 \text { (4 } \\
\text { mos-17 yrs) } \\
\mathrm{N}=13 \\
\text { Females: } 30.8 \text {, Males: } 69.2\end{array}$ & None reported \\
\hline $\begin{array}{l}\text { Cheng, 2005 } \\
\text { Hong Kong }\end{array}$ & $\begin{array}{l}\text { May 2003, Prince of } \\
\text { Wales Hospital }\end{array}$ & SARS, Lab-confirmed & $\begin{array}{l}\text { Age: } 4 \text { months, } \\
\mathrm{N}=1 \\
\text { Females: } 100, \text { Males: } 0\end{array}$ & None reported \\
\hline $\begin{array}{l}\text { Chiang, } 2003^{32} \\
\text { Taiwan }\end{array}$ & $\begin{array}{l}\text { April } 20 \text { to May } 7, \\
\text { 2003, two hospitals at } \\
\text { Taipei City }\end{array}$ & $\begin{array}{l}\text { SARS, WHO and CDC } \\
\text { Criteria }\end{array}$ & $\begin{array}{l}\text { Ages: } 26,27,36,42 \\
N=4, \\
\text { Females: } 50, \text { Males: } 50\end{array}$ & hepatitis B carrier, hyperthyroidism \\
\hline
\end{tabular}




\section{(L) ST. MICHAEL'S}

\begin{tabular}{|c|c|c|c|c|}
\hline $\begin{array}{l}\text { Author, Year; } \\
\text { Country of } \\
\text { Conduct }\end{array}$ & Study Period, Setting & $\begin{array}{l}\text { Diagnosis, } \\
\text { Diagnostic Criteria }\end{array}$ & $\begin{array}{l}\text { Age (variance), } \\
\text { Sample Size, } \\
\% \text { Female, \% Male }\end{array}$ & Co-morbidities \\
\hline $\begin{array}{l}\text { Gomersall, } \\
2004^{33} \\
\text { China }\end{array}$ & $\begin{array}{l}\text { Mar to Apr } 2003 \text {, } \\
\text { Intensive care unit in a } \\
\text { tertiary referral } \\
\text { university hospital }\end{array}$ & $\begin{array}{l}\text { SARS, } \\
\text { CDC Criteria }\end{array}$ & $\begin{array}{l}\text { Mean (SD): } 50(16.90) \\
N=54 \\
\text { Females: } 43, \text { Males: } 57\end{array}$ & None reported \\
\hline $\begin{array}{l}\text { Hon, } 2003^{36} \\
\text { Hong Kong }\end{array}$ & $\begin{array}{l}\text { March } 13 \text { to } 28,2003, \\
\text { Prince of Wales and } \\
\text { Princess Margaret } \\
\text { Hospitals }\end{array}$ & SARS, WHO Criteria & $\begin{array}{l}\text { Mean (range): } 9.66(1.5- \\
16.4) \\
N=10 \\
\text { Females: } 80, \text { Males: } 20\end{array}$ & None reported \\
\hline $\begin{array}{l}\text { Knowles, } 2003^{39} \\
\text { Canada }\end{array}$ & $\begin{array}{l}\text { NR, } \\
\text { Hospitals in Toronto }\end{array}$ & $\begin{array}{l}\text { SARS, } \\
\text { Probable/suspected }\end{array}$ & $\begin{array}{l}\text { Mean (range): } 46(17-99) \\
\mathrm{N}=110, \\
\text { Females: } 65, \text { Males: } 35\end{array}$ & None reported \\
\hline $\begin{array}{l}\text { Kwan, 2004 } \\
\text { Hong Kong }\end{array}$ & $\begin{array}{l}\text { NR, Hospital cluster in } \\
\text { Hong Kong }\end{array}$ & SARS, Lab-confirmed & $\begin{array}{l}\text { Mean (range): } 58(34-74) \\
\mathrm{N}=12 \\
\text { Females: } 50, \text { Males: } 50\end{array}$ & $\begin{array}{l}\text { Diabetic nephropathy (end-stage renal } \\
\text { failure); IgA nephropathy; lupus nephritis; } \\
\text { hypertensive nephrosclerosis; renal failure } \\
\text { unknown cause }\end{array}$ \\
\hline $\begin{array}{l}\text { Lam, } 2004^{41} \\
\text { Hong Kong }\end{array}$ & $\begin{array}{l}\text { March } 172003(28 \\
\text { days), Queen Mary } \\
\text { Hospital }\end{array}$ & SARS, Lab-confirmed & $\begin{array}{l}\text { Age: } 45 \\
\mathrm{~N}=1 \\
\text { Females: } 100, \text { Males: } 0\end{array}$ & $\begin{array}{l}\text { acute myeloid leukemia with successful } \\
\text { allogeneic bone marrow transplantation }\end{array}$ \\
\hline $\begin{array}{l}\text { Lau, } 2004^{42} \\
\text { Hong Kong }\end{array}$ & $\begin{array}{l}\text { Mar } 9 \text { to Apr 28, 2003, } \\
\text { Pamela Youde } \\
\text { Nethersole Eastern } \\
\text { Hospital }\end{array}$ & $\begin{array}{l}\text { SARS, WHO Criteria } \\
\text { (admission); } 68 / 71 \\
\text { cases lab-confirmed }\end{array}$ & $\begin{array}{l}\text { Mean (SD): } 42.5(14.8) \\
N=71 \\
\text { Females: NR, Males: } 38\end{array}$ & $\begin{array}{l}\text { Diabetes mellitus, coronary artery disease, } \\
\text { hypertensive heart disease, chronic renal } \\
\text { impairment, asthma, epilepsy, psychiatric } \\
\text { disease, chronic hepatitis virus b carrier }\end{array}$ \\
\hline $\begin{array}{l}\text { Lopez, } 2004^{44} \\
\text { Hong Kong }\end{array}$ & $\begin{array}{l}\text { February to July } 2003 \text {, } \\
\text { Chinese University of } \\
\text { Hong Kong and the } \\
\text { Hong Kong University }\end{array}$ & $\begin{array}{l}\text { SARS, Hong Kong } \\
\text { Hospital Authority }\end{array}$ & $\begin{array}{l}\text { Mean (range):36.25 }(28- \\
47) \\
\mathrm{N}=4 \text {, } \\
\text { Females: } 25 \text {, Males: } 75\end{array}$ & None reported \\
\hline $\begin{array}{l}\text { Poutanen, } \\
2003^{47} \\
\text { Canada }\end{array}$ & $\begin{array}{l}\text { February to March } \\
\text { 2003, First SARS } \\
\text { cases in Canada } \\
\text { (Toronto/Vancouver) }\end{array}$ & $\begin{array}{l}\text { SARS, } \\
\text { Probable/suspected }\end{array}$ & $\begin{array}{l}\text { Range: } 24-78, \\
N=10 \\
\text { Females: } 40, \text { Males: } 60\end{array}$ & $\begin{array}{l}\text { Type } 2 \text { diabetes mellitus, underlying } \\
\text { pulmonary disease, history of smoking }\end{array}$ \\
\hline
\end{tabular}




\section{(L) ST. MICHAEL'S}

\begin{tabular}{|c|c|c|c|c|}
\hline $\begin{array}{l}\text { Author, Year; } \\
\text { Country of } \\
\text { Conduct }\end{array}$ & Study Period, Setting & $\begin{array}{l}\text { Diagnosis, } \\
\text { Diagnostic Criteria }\end{array}$ & $\begin{array}{l}\text { Age (variance), } \\
\text { Sample Size, } \\
\% \text { Female, \% Male }\end{array}$ & Co-morbidities \\
\hline $\begin{array}{l}\text { So, } 2003^{49} \\
\text { Hong Kong }\end{array}$ & $\begin{array}{l}\text { March } 9 \text { to March 29, } \\
\text { 2003, } \\
\text { Pamela Youde } \\
\text { Nethersole Eastern } \\
\text { Hospital }\end{array}$ & SARS, WHO Criteria & $\begin{array}{l}\text { Mean (SD): } 39.6(13.3) \\
N=31 \\
\text { Females: NR, Males: } \\
35.48\end{array}$ & $\begin{array}{l}\text { Smokers, diabetes mellitus, hypertension, } \\
\text { coronary artery disease }\end{array}$ \\
\hline $\begin{array}{l}\text { Sung, 2004 } \\
\text { Hong Kong }\end{array}$ & $\begin{array}{l}\text { Mar } 11 \text { to Jul } 28,2003, \\
\text { Prince of Wales } \\
\text { Hospital }\end{array}$ & SARS, Lab-confirmed & $\begin{array}{l}\text { Mean (SD): } 39.3(16.8) \\
\mathrm{N}=138 \\
\text { Females: } 52 \text {, Males: } 48\end{array}$ & None reported \\
\hline $\begin{array}{l}\text { Tang, 200352 } \\
\text { Hong Kong }\end{array}$ & $\begin{array}{l}\text { March } 31 \text { to April } 6 \\
\text { 2003, Princess } \\
\text { Margaret Hospital }\end{array}$ & SARS, Lab-confirmed & $\begin{array}{l}\text { Ages: } 49 \text { and } 86, \\
N=2 \text {, } \\
\text { Females: } 0 \text {, Males: } 100\end{array}$ & $\begin{array}{l}\text { End-stage renal failure, diabetes mellitus, } \\
\text { hypertension, ischemic heart disease, a } \\
\text { history of cerebral infarction, thalassemia } \\
\text { minor }\end{array}$ \\
\hline $\begin{array}{l}\text { Tiwari, } 2003^{53} \\
\text { China }\end{array}$ & $\begin{array}{l}\text { March } 2003 \text { - May } \\
\text { 2003, } \\
\text { Queen Mary Hospital }\end{array}$ & SARS, WHO Criteria & $\begin{array}{l}\text { Median (range): } 38(22- \\
82) \\
N=36 \\
\text { Females: } 58, \text { Males: } 42\end{array}$ & None reported \\
\hline $\begin{array}{l}\text { Tsang, } 2003^{54} \\
\text { Hong Kong }\end{array}$ & $\begin{array}{l}\text { February 22, } 2003 \text { to } \\
\text { March 22, 2003, } \\
\text { Queen Mary Hospital, } \\
\text { Kwong Wah Hospital, } \\
\text { and Pamela Youde } \\
\text { Nethersole Eastern } \\
\text { Hospital }\end{array}$ & $\begin{array}{l}\text { SARS, CDC Criteria; } \\
\text { Clinical criteria (chest } \\
\text { radiographs) }\end{array}$ & $\begin{array}{l}\text { Mean (SD): } 52.5(11) \\
N=10 \\
\text { Females: } 50, \text { Males: } 50\end{array}$ & $\begin{array}{l}\text { Hypertension, benign prostatic } \\
\text { hypertrophy, ischemic heart disease, type } \\
2 \text { diabetes mellitus, resected renal-cell } \\
\text { carcinoma of the right kidney }\end{array}$ \\
\hline $\begin{array}{l}\text { Tsui, } 2003^{55} \\
\text { China }\end{array}$ & $\begin{array}{l}\text { Apr } 2003 \text { - May 2003, } \\
\text { Princess Margaret } \\
\text { Hospital and Wong Tai } \\
\text { Sin Hospital }\end{array}$ & $\begin{array}{l}\text { SARS, Hong Kong } \\
\text { Hospital Authority } \\
\text { Criteria }\end{array}$ & $\begin{array}{l}\text { Median (range): } 41(18-83) \\
\mathrm{N}=323 \\
\text { Females: } 60.7 \text {, Males: } 39.3\end{array}$ & $\begin{array}{l}\text { Hypertension, diabetes, chronic lung } \\
\text { disease, pregnancy, neurologic disease, } \\
\text { renal disease, cardiovascular disease, } \\
\text { immunologic disease, malignancy }\end{array}$ \\
\hline $\begin{array}{l}\text { Wu, 200359 } \\
\text { China }\end{array}$ & $\begin{array}{l}\text { Jan } 30 \text { to Mar 10, } \\
2003 \text {, } \\
\text { The Second Affiliated } \\
\text { Hospital, Sun Yat-sen } \\
\text { University }\end{array}$ & $\begin{array}{l}\text { SARS, } \\
\text { Probable/suspected }\end{array}$ & $\begin{array}{l}\text { Mean (SD): } 29.5(10.3) \\
\mathrm{N}=96 \\
\text { Females: } 79, \text { Males: } 21\end{array}$ & None reported \\
\hline
\end{tabular}




\section{(L) ST. MICHAEL'S}

\begin{tabular}{|c|c|c|c|c|}
\hline $\begin{array}{l}\text { Author, Year; } \\
\text { Country of } \\
\text { Conduct }\end{array}$ & Study Period, Setting & $\begin{array}{l}\text { Diagnosis, } \\
\text { Diagnostic Criteria }\end{array}$ & $\begin{array}{l}\text { Age (variance), } \\
\text { Sample Size, } \\
\% \text { Female, \% Male }\end{array}$ & Co-morbidities \\
\hline $\begin{array}{l}\text { Wong, } 2003^{58} \\
\text { Hong Kong }\end{array}$ & $\begin{array}{l}\text { March 2003, Kwong } \\
\text { Wah Hospital }\end{array}$ & SARS, WHO Criteria & $\begin{array}{l}\text { Mean (SD): } 66.3(13.5) \\
N=11 \\
\text { Females: } 100, \text { Males: } 0\end{array}$ & $\begin{array}{l}\text { Renal failure, diabetes mellitus, } \\
\text { tuberculous lymphadenitis }\end{array}$ \\
\hline $\begin{array}{l}\text { Al-Tawfiq, } \\
2013^{27} \\
\text { Saudi Arabia }\end{array}$ & $\begin{array}{l}\text { April - May 2013, } \\
\text { Saudi Aramco Medical } \\
\text { Services Organization }\end{array}$ & MERS, Lab-confirmed & $\begin{array}{l}\text { Median (range): } 62(24- \\
81) \\
N=5 \\
\text { Females: } 40 ; \text { Males: } 60\end{array}$ & $\begin{array}{l}\text { Chronic kidney disease, hypertension, } \\
\text { diabetes, asthma, obstructive sleep apnea, } \\
\text { coronary heart disease, atrial fibrillation, } \\
\text { end-stage renal disease }\end{array}$ \\
\hline $\begin{array}{l}\text { Al-Tawfiq, } \\
2018^{26} \\
\text { Saudi Arabia }\end{array}$ & $\begin{array}{l}\text { NR, Johns Hopkins } \\
\text { Aramco Healthcare }\end{array}$ & MERS, Lab-confirmed & $\begin{array}{l}\text { Ages: } 52,53,56 \\
N=3 \text {, } \\
\text { Females: } 0 \text {, Males: } 100\end{array}$ & Rheumatoid arthritis \\
\hline $\begin{array}{l}\text { Habib, } 2015^{34} \\
\text { UAE }\end{array}$ & NR, Mafraq Hospital & MERS, Lab-confirmed & $\begin{array}{l}\text { Age: } 32, \\
\mathrm{~N}=1 \\
\text { Females: } 100, \text { Males: } 0\end{array}$ & Pregnancy (32 weeks) \\
\hline $\begin{array}{l}\text { Khalid, } 2015^{37} \\
\text { Saudi Arabia }\end{array}$ & $\begin{array}{l}\text { Apr to May 2014, King } \\
\text { Faisal Specialist } \\
\text { Hospital \& Research } \\
\text { Center-Jeddah }\end{array}$ & MERS, Lab-confirmed & $\begin{array}{l}\text { Mean: } 53 \\
N=14 \\
\text { Females: NR, Males: } 16\end{array}$ & None reported \\
\hline $\begin{array}{l}\text { Kim, } 2016^{38} \\
\text { Korea }\end{array}$ & $\begin{array}{l}\text { NR, Pusan National } \\
\text { University Hospital }\end{array}$ & MERS, Lab-confirmed & $\begin{array}{l}\text { Age: } 54 \\
\mathrm{~N}=1 \text {, } \\
\text { Females } 0 \% \text { female, } 100 \% \\
\text { male }\end{array}$ & None reported \\
\hline $\begin{array}{l}\text { Lee, } 2017^{43} \\
\text { South Korea }\end{array}$ & $\begin{array}{l}\text { May } 11 \text { to June } 28, \\
2015, \text { The National } \\
\text { Medical Center }\end{array}$ & $\begin{array}{l}\text { MERS, Clinical criteria } \\
\text { (blood tests, chest } \\
\text { radiographs) }\end{array}$ & $\begin{array}{l}\text { Age: } 68 \\
\mathrm{~N}=1 \\
\text { Females: } 0 \text {, Males: } 100\end{array}$ & $\begin{array}{l}\text { hypertension, dyslipidemia, current heavy } \\
\text { smoker }\end{array}$ \\
\hline $\begin{array}{l}\text { Motabi, } 2016^{45} \\
\text { Saudi Arabia }\end{array}$ & $\begin{array}{l}\text { March to May } 2015 \text {, } \\
\text { King Fahad Medical } \\
\text { City }\end{array}$ & MERS, Lab-confirmed & $\begin{array}{l}\text { Ages: } 22,62,65,76 \\
N=4 \\
\text { Females: } 50 \text {, Males: } 50\end{array}$ & $\begin{array}{l}\text { Hematological malignancies; B symptoms } \\
\text { and huge organomegaly due to stage IV } \\
\text { DLBCL; Acute myeloid leukemia; IgA } \\
\text { kappa multiple myeloma with h/o HTN and } \\
\text { CKD) }\end{array}$ \\
\hline $\begin{array}{l}\text { Shalhoub, } \\
2014^{48} \\
\text { Saudi Arabia }\end{array}$ & $\begin{array}{l}\text { April - June 2014, King } \\
\text { Fahad Armed Forces } \\
\text { Hospital }\end{array}$ & MERS, Lab-confirmed & $\begin{array}{l}\text { Age: } 51 \\
\mathrm{~N}=1 \\
\text { Females: } 0 \text {, Males: } 100\end{array}$ & HIV infection \\
\hline
\end{tabular}




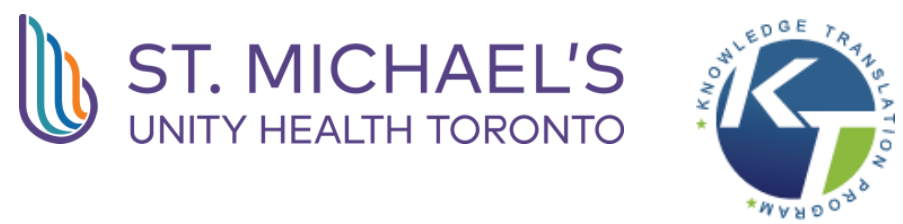

\begin{tabular}{|c|c|c|c|c|}
\hline $\begin{array}{l}\text { Author, Year; } \\
\text { Country of } \\
\text { Conduct }\end{array}$ & Study Period, Setting & $\begin{array}{l}\text { Diagnosis, } \\
\text { Diagnostic Criteria }\end{array}$ & $\begin{array}{l}\text { Age (variance), } \\
\text { Sample Size, } \\
\% \text { Female, \% Male }\end{array}$ & Co-morbidities \\
\hline $\begin{array}{l}\text { Spanakis, } 2014^{50} \\
\text { Greece }\end{array}$ & $\begin{array}{l}\text { NR, A tertiary care } \\
\text { centre and 'Sotiria' } \\
\text { Chest Diseases } \\
\text { Hospital of Athens }\end{array}$ & MERS, Lab-confirmed & $\begin{array}{l}\text { Age: } 69 \\
\mathrm{~N}=1 \\
\text { Females: } 0 \text {, Males: } 100\end{array}$ & None reported \\
\hline $\begin{array}{l}\text { Bogdanov, } \\
2017^{29} \\
\text { Germany }\end{array}$ & $\begin{array}{l}\text { NR, University Hospital } \\
\text { of Essen }\end{array}$ & $\begin{array}{l}\text { Other coronavirus, Lab- } \\
\text { confirmed }\end{array}$ & $\begin{array}{l}\text { Age: } 30 \\
N=1 \\
\text { Females: } 0 \text {, Males: } 100\end{array}$ & $\begin{array}{l}\text { acute lymphoblastic leukemia, graft- } \\
\text { versus-host disease post bone marrow } \\
\text { transplant (grade 1) }\end{array}$ \\
\hline $\begin{array}{l}\text { Oger, } 2017^{46} \\
\text { France }\end{array}$ & $\begin{array}{l}\text { May } 2013 \text { - Oct } 2015 \text {, } \\
\text { Hospital }\end{array}$ & Other coronavirus, NR & $\begin{array}{l}\text { Age: } 57 \\
N=1 \\
N A\end{array}$ & None reported \\
\hline
\end{tabular}

CDC - Centers for Disease Control; MERS - Middle East Respiratory Syndrome; SARS - Severe Acute Respiratory Syndrome; WHO - World Health Organization; SD - Standard Deviation; IQR - Interquartile Range; NR -Not Reported; NA -Not applicable 


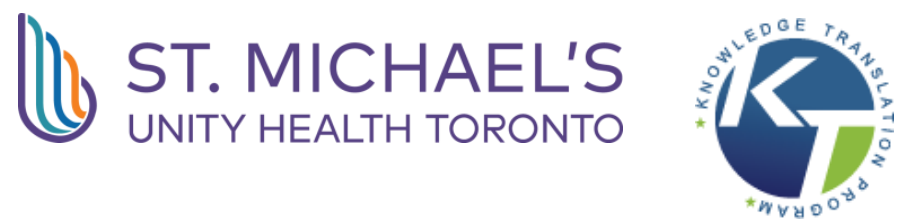

\section{APPENDIX 4 - Detailed Table of Interventions and Outcomes}

\begin{tabular}{|c|c|c|c|}
\hline $\begin{array}{l}\text { Author, } \\
\text { Year; } \\
\text { Diagnosis }\end{array}$ & $\begin{array}{c}\text { Drug therapy (sample size) } \\
\text { [dose, route of administration, frequency, } \\
\text { duration] }\end{array}$ & Effectiveness Outcomes & Safety Outcomes \\
\hline \multicolumn{4}{|c|}{ Controlled trials $n=3$} \\
\hline \multirow{2}{*}{$\begin{array}{l}\text { Lee, } 2004^{6} \\
\text { SARS }\end{array}$} & $\begin{array}{l}\text { Initial antibacterial therapy } \\
\text { Ribavirin }(n=9) \\
\text { [ } 400 \text { mg every eight hours, total of } 12 \text { days] } \\
\text { "Early Hydrocortisone }(n=9) \\
\text { [100mg every eight hours] }\end{array}$ & $\begin{array}{l}\text { ICU admission + ventilation and } \\
\text { subsequent mortality: } 1 \text { patient }\end{array}$ & NR \\
\hline & $\begin{array}{l}\text { Initial antibacterial therapy } \\
\text { Ribavirin ( } n=7) \\
\text { [ } 400 \text { mg every eight hours, total of } 12 \text { days] } \\
\text { Placebo }(n=7) \\
\text { [5mg intravenous saline every eight hours] }\end{array}$ & $\begin{array}{l}\text { ICU admission + ventilation: } 0 \text { patients } \\
\text { Mortality: } 0 \text { patients }\end{array}$ & NR \\
\hline \multirow{3}{*}{$\begin{array}{l}\text { Zhao, } 2003^{8} \\
\text { SARS }\end{array}$} & $\begin{array}{l}\text { Group A }(\mathrm{n}=40) \\
\text { Ribavirin } \\
\text { [0.4-0.6 g, twice daily, intravenous] } \\
\text { Cefoperazone/sulbactam } \\
{[2.0 \mathrm{~g} \text {, twice daily, intravenous] }}\end{array}$ & Mortality: 2 patients & NR \\
\hline & $\begin{array}{l}\text { Group B }(\mathrm{n}=30) \\
\text { Fluoroquinolone plus azithromycin }[0.4 \mathrm{~g}, \\
\text { intravenous] } \\
\text { recombinant interferon-alpha (IFN-a) } \\
\text { [3 } 000000 \text { units, intramuscular] }\end{array}$ & Mortality: 2 patients & NR \\
\hline & Group C $(n=60)$ & Mortality: 7 patients & NR \\
\hline
\end{tabular}




\section{(1) ST. MICHAEL'S}

\begin{tabular}{|c|c|c|c|}
\hline $\begin{array}{l}\text { Author, } \\
\text { Year; } \\
\text { Diagnosis }\end{array}$ & $\begin{array}{l}\text { Drug therapy (sample size) } \\
\text { [dose, route of administration, frequency, } \\
\text { duration] }\end{array}$ & Effectiveness Outcomes & Safety Outcomes \\
\hline & $\begin{array}{l}\text { Quinolone plus azithromycin } \\
\text { [0.4 g, intravenous] } \\
\text { Recombinant IFN-a } \\
\text { [3 } 000000 \text { units, intramuscular] } \\
\text { Methylprednisolone (added when symptoms } \\
\text { worsened) } \\
\text { [80-160 mg per day for } 2-3 \text { days] }\end{array}$ & & \\
\hline & $\begin{array}{l}\text { Group } D(n=60) \\
\text { Levofloxacin } \\
{[0.2 \mathrm{~g} \text {, twice daily, intravenous] }} \\
\text { Azithromycin } \\
\text { [0.6 g, intravenous] } \\
\text { Recombinant IFN-a ( } \mathrm{n}=45) \\
\text { [3 } 000000 \text { units, intramuscular] } \\
\text { Methylprednisolone (added when symptoms } \\
\text { worsened) } \\
{[160-1000 \text { mg per day depending on symptoms, }} \\
5-14 \text { days] }\end{array}$ & Mortality: 0 patients & NR \\
\hline $\begin{array}{l}\text { Park, } \\
2019^{7 \star \star} \\
\text { Prophylaxis } \\
\text { (MERS) }\end{array}$ & $\begin{array}{l}\text { Ribavirin }(\mathrm{n}=22) \\
\text { [loading dose } 2000 \mathrm{mg} ; 1200 \mathrm{mg} \text { every } 8 \mathrm{~h} \text { for } 4 \\
\text { days then } 600 \mathrm{mg} \text { every } 8 \mathrm{~h} \text { for } 6-8 \text { days] } \\
\text { Lopinavir/ritonavir ( } \mathrm{n}=22) \\
\text { [administered orally; } 400 \mathrm{mg} / 100 \mathrm{mg} \text { every } 12 \mathrm{~h} \\
\text { for } 11-13 \text { days] }\end{array}$ & $\begin{array}{l}\text { Confirmed infection with MERS-Cov: } 0 \\
\text { patients } \\
\text { Risk of infection (prophylaxis v control): } \\
\text { Odds Ratio: } 0.405 \text {, } \\
95 \% \mathrm{Cl}: 0.274 \text { to } 0.599, \quad p=0.009\end{array}$ & $\begin{array}{l}\text { Diarrhea: } 9 \text { patients } \\
\text { Nausea: } 9 \text { patients } \\
\text { Stomatitis: } 4 \text { patients } \\
\text { Fever: } 3 \text { patients } \\
\text { Anemia: } 9 \text { patients } \\
\text { Lecuopenia: } 8 \text { patients } \\
\text { Hyperbilirubinemia: } 20 \text { patients } \\
\text { [all occurred during PEP therapy } \\
\text { and normalized upon conclusion of }\end{array}$ \\
\hline
\end{tabular}




\section{(1) ST. MICHAEL'S}

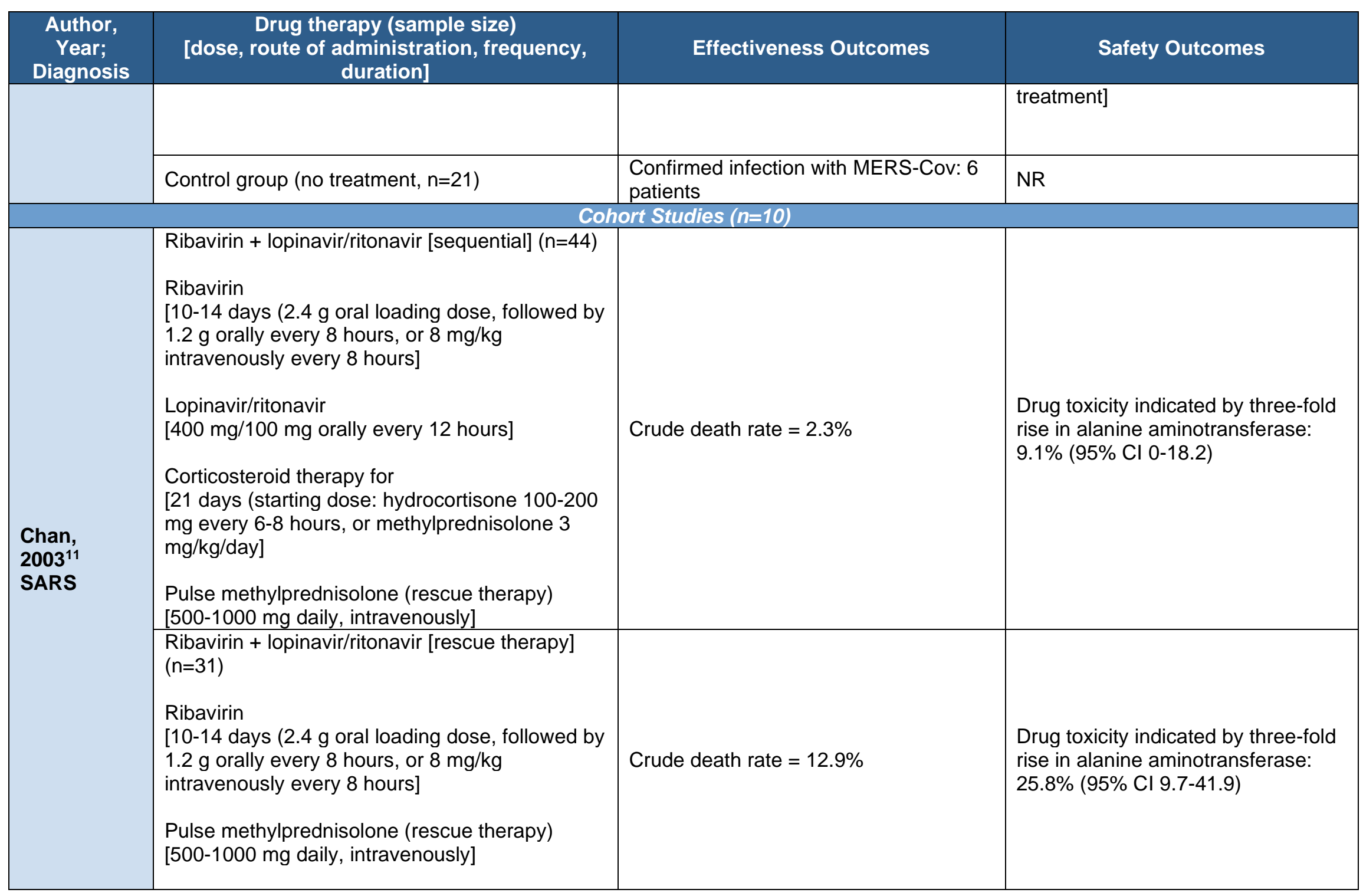




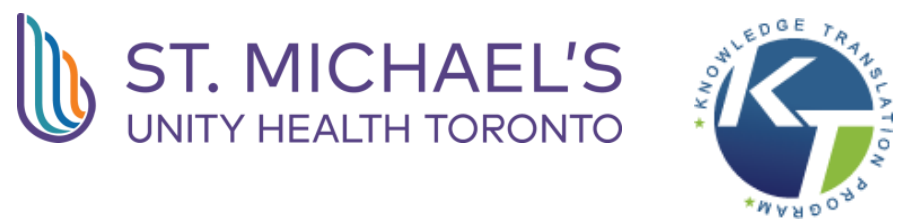

\begin{tabular}{|c|c|c|c|}
\hline \multirow[t]{2}{*}{$\begin{array}{l}\text { Author, } \\
\text { Year; } \\
\text { Diagnosis }\end{array}$} & $\begin{array}{l}\text { Drug therapy (sample size) } \\
\text { [dose, route of administration, frequency, } \\
\text { duration] }\end{array}$ & Effectiveness Outcomes & Safety Outcomes \\
\hline & $\begin{array}{l}\text { If above treatments failed added as rescue } \\
\text { therapy: } \\
\text { Lopinavir/ritonavir } \\
\text { [ } 400 \mathrm{mg} / 100 \mathrm{mg} \text { orally every } 12 \text { hours] }\end{array}$ & & \\
\hline \multirow[t]{2}{*}{$\begin{array}{l}\text { Chu, } 2004^{13} \\
\text { SARS }\end{array}$} & $\begin{array}{l}\text { Lopinavir/ritonavir }(n=41) \\
\text { [400mg/100 mg orally every } 12 \text { hours for } 14 \\
\text { days] }\end{array}$ & 21-day mortality: 0 patients & $\begin{array}{l}\text { Gastrointestinal upset: } \\
11 \text { patients } \\
\text { Liver dysfunction: } \\
7 \text { patients } \\
\text { Headache: } 6 \text { patients } \\
\text { Blurred vision: } 3 \text { patients }\end{array}$ \\
\hline & Ribavirin $(n=111)$ & 21-day mortality: 7 patients & NR \\
\hline \multirow{2}{*}{$\begin{array}{l}\text { Guo, } 2019^{14} \\
\text { SARS }\end{array}$} & $\begin{array}{l}\mathrm{n}=34 \\
\text { Antibiotics } \\
\text { [penicillin, fluoroquinolone, or macrolides] } \\
\text { Oseltamivir } \\
\text { [oral, } 75 \mathrm{mg}, 2 \times \text { a day for } 5 \text { days and } 75 \mathrm{mg} 1 \times \text { a } \\
\text { day for another } 7 \text { days] }\end{array}$ & $\begin{array}{l}\text { ICU admission: } 25 \text { patients; oseltamivir } \\
\text { treatment was not found to be } \\
\text { associated with significantly better } \\
\text { outcomes ( } p>0.05 \text {, data not shown) } \\
21 \text {-day mortality: } 3 \text { patients, }(p=0.682 \text { ) }\end{array}$ & $\begin{array}{l}\text { Lung function abnormalities (post- } \\
\text { recovery): } 7 \text { patients }\end{array}$ \\
\hline & $\begin{array}{l}\mathrm{n}=69 \\
\text { Antibiotics } \\
\text { [penicillin, fluoroquinolone, or macrolides] } \\
\text { Corticosteroids (if no response to antibiotics) } \\
\text { [intravenous, } 50-500 \mathrm{mg} / \mathrm{day}, \text { modifications were } \\
\text { made according to the needs of individual } \\
\text { patients] }\end{array}$ & $\begin{array}{l}\text { ICU admission: } 19 \text { patients } \\
\text { 21-day mortality: } 4 \text { patients }\end{array}$ & $\begin{array}{l}\text { Lung function abnormalities (post- } \\
\text { recovery): } 7 \text { patients }\end{array}$ \\
\hline $\begin{array}{l}\text { Ho, } 2003^{15} \\
\text { SARS }\end{array}$ & $\begin{array}{l}\mathrm{N}=55 \\
\text { Ribavirin }\end{array}$ & $\begin{array}{l}\text { ICU admission: } 11 \text { patients, } 5 \text { needed } \\
\text { mechanical ventilation }\end{array}$ & $\begin{array}{l}\text { Hemolytic anemia ( } 1.5 x \text { increase in } \\
\text { bilirubin): } 16 \text { patients }\end{array}$ \\
\hline
\end{tabular}




\section{(I) ST. MICHAEL'S \\ UNITY HEALTH TORONTO}

\begin{tabular}{|c|c|c|c|}
\hline $\begin{array}{l}\text { Author, } \\
\text { Year; } \\
\text { Diagnosis }\end{array}$ & $\begin{array}{c}\text { Drug therapy (sample size) } \\
\text { [dose, route of administration, frequency, } \\
\text { duration] }\end{array}$ & Effectiveness Outcomes & Safety Outcomes \\
\hline & $\begin{array}{l}\text { [8 mg/kg, intravenously three times a day for the } \\
7 \text { days and then orally at } 1.2 \mathrm{~g} \text { three times a day } \\
\text { for altogether } 10-14 \text { days] } \\
\text { 'Non pulse steroid' hydrocortisone }(\mathrm{n}=34 \text { ) } \\
\text { [2 } \mathrm{mg} / \mathrm{kg} \text {, intravenously four times a day or } 4 \\
\mathrm{mg} / \mathrm{kg} \text {, intravenously three times a day for } 3-5 \\
\text { days, followed by oral prednisolone at } 2 \mathrm{mg} / \mathrm{kg} \\
\text { daily at reducing dosage] } \\
\text { [or] } \\
\text { Methylprednisolone ( } \mathrm{n}=21 \text { ) } \\
2-3 \mathrm{mg} / \mathrm{kg} \text {, intravenously once daily for } 5 \text { days, } \\
\text { followed by oral prednisolone at } 2 \mathrm{mg} / \mathrm{kg} \text { daily at } \\
\text { reducing dosage] } \\
45 \text { patients received pulse steroids as rescue } \\
\text { therapy }\end{array}$ & $\begin{array}{l}\text { Mortality: } 3 \text { patients; no statistical } \\
\text { difference between the PS group and } \\
\text { the NPS group in mortality during the } 3 \\
\text { weeks of SARS treatment }\end{array}$ & $\begin{array}{l}\text { Hyperglycemia (random blood } \\
\text { glucose } \geq 11 \mathrm{mmol} / \mathrm{L} \text { ): } 18 \text { patients } \\
\text { Serious secondary infection } \\
\text { (pyrexial or bacteremic): } 2 \text { patients } \\
\text { Hematemesis: } 2 \text { patients }\end{array}$ \\
\hline & $\begin{array}{l}\mathrm{N}=17 \\
\text { Ribavirin } \\
\text { [8 } \mathrm{mg} / \mathrm{kg} \text {, intravenously three times a day for the } \\
7 \text { days and then orally at } 1.2 \mathrm{~g} \text { three times a day } \\
\text { for altogether } 10-14 \text { days] } \\
\text { Pulse methylprednisolone } \\
\text { [500 mg, intravenously once daily for } 5-7 \text { days } \\
\text { or } 1 \mathrm{~g} \text {, intravenously once daily for } 3 \text { days, } \\
\text { followed by maintenance oral prednisolone } 50 \\
\text { mg two times a day reducing to } 20-30 \text { mg daily } \\
\text { on Day 21)] }\end{array}$ & $\begin{array}{l}\text { ICU admission: } 1 \text { patient that required } \\
\text { mechanical ventilation } \\
\text { Mortality: } 1 \text { patient }\end{array}$ & $\begin{array}{l}\text { hemolytic anemia ( } 1.5 x \text { increase in } \\
\text { bilirubin): } 8 \text { patients } \\
\text { Hyperglycemia (random blood } \\
\text { glucose } \geq 11 \mathrm{mmol} / \mathrm{L} \text { ): } 0 \text { patients } \\
\text { Serious secondary infection } \\
\text { (pyrexial or bacteremic): } 1 \text { patient } \\
\text { Hematemesis: } 1 \text { patient }\end{array}$ \\
\hline \multirow[t]{2}{*}{$\begin{array}{l}\text { Lau, } 2009^{16} \\
\text { SARS }\end{array}$} & $\begin{array}{l}\text { Hong Kong - Ribavirin }(n=202) \\
\text { Toronto - Ribavirin }(n=107)\end{array}$ & $\begin{array}{l}\text { Mortality [Hong Kong]: } 18 \text { patients } \\
\text { Mortality [Toronto]: } 10 \text { patients }\end{array}$ & NR \\
\hline & Hong Kong - Ribavirin, corticosteroids ( $\mathrm{n}=739$ ) & Mortality [Hong Kong]: 93 patients & NR \\
\hline
\end{tabular}




\section{UL ST. MICHAEL'S \\ UNITY HEALTH TORONTO}

\begin{tabular}{|c|c|c|c|}
\hline $\begin{array}{l}\text { Author, } \\
\text { Year; } \\
\text { Diagnosis }\end{array}$ & $\begin{array}{c}\text { Drug therapy (sample size) } \\
\text { [dose, route of administration, frequency, } \\
\text { duration] }\end{array}$ & Effectiveness Outcomes & Safety Outcomes \\
\hline & Toronto - Ribavirin, corticosteroids $(n=39)$ & Mortality [Toronto]: 5 patients & \\
\hline \multirow{2}{*}{$\begin{array}{l}\text { Leong, } \\
2004^{17} \\
\text { SARS }\end{array}$} & $\begin{array}{l}\text { Ribavirin treatment }(\mathrm{n}=97) \\
\text { Oral ribavirin was dosed at } 1.2 \mathrm{~g} \text { three times a } \\
\text { day; intravenous ribavirin at } 400 \mathrm{mg} \text { every } 8 \mathrm{~h} \\
\text { for sicker patients and those who could not take } \\
\text { it per os. Patients received ribavirin for } 5.6(2.5) \\
\text { days on average; } 21 \text { patients received steroids, } \\
84 \text { received antibiotics }\end{array}$ & $\begin{array}{l}\text { ICU admission: } 19 \text { patients; no } \\
\text { significant difference in the proportion of } \\
\text { patients admitted to ICU between the } 2 \\
\text { groups ( } p>0.999 \text { ) } \\
\text { Mortality ( } n=10 \text { ): } 10 \text { patients; } \\
\text { Adjusted hazard ratio (ribavirin v } \\
\text { control): } 1.03,95 \% \mathrm{Cl}: 0.44-2.41, p= \\
0.939\end{array}$ & $\begin{array}{l}\text { Myocardial injury: } 3 \text { patients, } \\
\text { occurred between admission till day } \\
14 \text { of illness } \\
\text { Anemia: } 24 \text { patients, occurred } \\
\text { between admission to day } 14 \text { if } \\
\text { illness }\end{array}$ \\
\hline & $\begin{array}{l}\text { Control }(n=132) \\
17 \text { patients received steroids (hydrocortisone, } \\
\text { prednisolone and/or methylprednisolone), } 94 \\
\text { received antibiotics }\end{array}$ & $\begin{array}{l}\text { ICU/Critical care }(n=27) \text { - } \\
\text { admission to ICU } \\
\text { Mortality }(n=17)\end{array}$ & $\begin{array}{l}\text { Myocardial injury: } 4 \text { patients, } \\
\text { occurred between admission till day } \\
14 \text { of illness } \\
\text { Anemia: } 27 \text { patients, occurred } \\
\text { between admission to day } 14 \text { if } \\
\text { illness }\end{array}$ \\
\hline \multirow[t]{2}{*}{$\begin{array}{l}\text { Li, } 2006^{18} \\
\text { SARS }\end{array}$} & $\begin{array}{l}\text { Ribavirin }(n=63) \\
\text { The Western Medicine protocol included oxygen } \\
\text { supplementation, hemofiltration, ribavirin, } \\
\text { antibacterials (azithromycin, cefuroxime, } \\
\text { metronidazole), and immunoregulation with } \\
\text { thymosin injection. Methylprednisolone, } \\
\text { prednisolone or dexamethasone was used when } \\
\text { clinically appropriate. }\end{array}$ & Mortality: 7 patients & (1) \\
\hline & $\begin{array}{l}\text { Ribavirin + Traditional Chinese Medicine }(\mathrm{n}= \\
52) \\
\text { In the combined treatment protocol, the herbal } \\
\text { medication Herba houttuyniae injection was }\end{array}$ & Mortality: 5 patients & NR \\
\hline
\end{tabular}




\section{(1) ST MICHAEL'S}

\begin{tabular}{|c|c|c|c|}
\hline $\begin{array}{l}\text { Author, } \\
\text { Year; } \\
\text { Diagnosis }\end{array}$ & $\begin{array}{c}\text { Drug therapy (sample size) } \\
\text { [dose, route of administration, frequency, } \\
\text { duration] }\end{array}$ & Effectiveness Outcomes & Safety Outcomes \\
\hline & $\begin{array}{l}\text { employed together with the WM treatments. } \\
\text { When necessary, patients in this group also } \\
\text { received TCM decoctions such as the heat- } \\
\text { clearing and detoxifying prescription, the qi- } \\
\text { supplementing prescription, and the blood- } \\
\text { regulating prescription according to their ZHENG } \\
\text { conditions by consulting with the Chinese } \\
\text { herbalist from the China-Japan Friendship } \\
\text { Hospital }\end{array}$ & & \\
\hline \multirow{2}{*}{$\begin{array}{l}\text { Alkhadhairi, } \\
2018^{9} \\
\text { MERS }\end{array}$} & $\begin{array}{l}\text { Oral ribavirin with PEGylated interferon } \alpha 2 a \\
\text { injection }(n=49)\end{array}$ & Mortality: 24 patients $(p=0.182)$ & $\begin{array}{l}\text { Mean rise in serum creatinine } \\
(\mathrm{n}=49): 2.14 \mathrm{mg} / \mathrm{dl} \\
\text { Mean rise in urea nitrogen }(\mathrm{n}=49) \\
42 \mathrm{mg} / \mathrm{dl}\end{array}$ \\
\hline & Supportive care alone $(n=64)$ & Mortality: 23 patients & $\begin{array}{l}\text { Mean rise in serum creatinine }(n= \\
64): 1.36 \mathrm{mg} / \mathrm{dl} \\
\text { Mean rise in urea nitrogen }(\mathrm{n}=64) \\
39 \mathrm{mg} / \mathrm{dl}\end{array}$ \\
\hline \multirow[t]{2}{*}{$\begin{array}{l}\text { Arabi, } \\
2019^{10 * *} \\
\text { MERS }\end{array}$} & $\begin{array}{l}\text { Ribavirin/rIFN combination* }(n=117) \\
\text { Ribavirin alone }(n=18) \\
\text { rIFN alone* }(n=9) ; \\
{ }^{*} \text { rIFNs used include: IFN- } \alpha 2 a(n=73), r I F N ~ \alpha-2 b \\
(n=22), \text { rIFN- } \beta 1 a(n=31), \text { rIFN- } \beta 1 b(n=0) ; \\
\text { Additional therapies: } \\
\text { Corticosteroids }(n=86) \\
\text { Oseltamivir }(n=67)\end{array}$ & $\begin{array}{l}\text { Crude } 90 \text {-day mortality: } 106 \text { patients } \\
(p=0.02) \\
\text { Risk of } 90 \text {-day mortality (ribavirin/rIFN v } \\
\text { control) } \\
\text { adjusted odds ratio: } 2.27,95 \% \mathrm{Cl} 1.20- \\
4.32 ; p=0.01\end{array}$ & $\begin{array}{l}\text { Required blood transfusions: } 58 \\
\text { patients }(p=0.02)\end{array}$ \\
\hline & $\begin{array}{l}\text { Control }(n=205) \\
\text { Use of corticosteroids or oseltamivir only }\end{array}$ & Crude 90-day mortality: 126 patients & $\begin{array}{l}\text { Required blood transfusions: } 58 \\
\text { patients }\end{array}$ \\
\hline \multirow{2}{*}{$\begin{array}{l}\text { Choi, } 2016^{12} \\
\text { MERS }\end{array}$} & $\begin{array}{l}\text { Ribavirin; lopinavir/ritonavir; interferon } \\
(\mathrm{n}=112)\end{array}$ & Mortality: 20 patients & NR \\
\hline & Ribavirin, interferon $(\mathrm{n}=17)$ & Mortality: 1 patient & NR \\
\hline
\end{tabular}




\section{UL ST. MICHAEL'S \\ UNITY HEALTH TORONTO}

\begin{tabular}{|c|c|c|c|}
\hline $\begin{array}{l}\text { Author, } \\
\text { Year; } \\
\text { Diagnosis }\end{array}$ & $\begin{array}{c}\text { Drug therapy (sample size) } \\
\text { [dose, route of administration, frequency, } \\
\text { duration] }\end{array}$ & Effectiveness Outcomes & Safety Outcomes \\
\hline & Ribavirin; lopinavir/ritonavir $(\mathrm{n}=7)$ & Mortality: 4 patients & NR \\
\hline & Ribavirin $(n=1)$ & Mortality: 0 patients & NR \\
\hline & lopinavir/ritonavir $(\mathrm{n}=1)$ & Mortality: 0 patients & NR \\
\hline & Antivirals (unspecified), interferon $(n=138)$ & Mortality: 25 patients & NR \\
\hline \multicolumn{4}{|c|}{ Retrospective Studies ( $n=7)$} \\
\hline $\begin{array}{l}\text { Booth, } \\
2003^{20 * *} \\
\text { SARS }\end{array}$ & $\begin{array}{l}\text { Ribavirin }(n=126 / 144) \\
\text { [2g intravenous loading dose, } 1 \mathrm{~g} \text { intravenous } \\
\text { every } 6 \text { hrs for } 4 \text { days, } 500 \text { mg every } 8 \text { hrs for } 3 \\
\text { days; median (IQR) treatment course: } 6 \text { days (5- } \\
\text { 7)] } \\
\text { Antibiotic therapy (NR) } \\
\text { [NR] }\end{array}$ & $\begin{array}{l}\text { ICU Admission: } 29 \text { patients } \\
\text { Mechanical ventilation in ICU: } 20 \\
\text { patients } \\
\text { Mortality: } 8 \text { patients (all admitted to } \\
\text { ICU) } \\
21-\text { day mortality rate: } 6.5 \% \\
(95 \% \mathrm{Cl} 1.9 \%-11.8 \%)\end{array}$ & $\begin{array}{l}\text { Decreased hemoglobin levels: } 71 \\
\text { patients } \\
\text { Hemolysis: } 8 \text { patients (all with } \\
\text { decreased hemoglobin) } \\
\text { Bradycardia: } 18 \text { patients }\end{array}$ \\
\hline $\begin{array}{l}\text { Chiou, } \\
2005^{21} \\
\text { SARS }\end{array}$ & $\begin{array}{l}\text { Initial antibiotic therapy on admission for } \\
\text { pneumonia ( } n=53 / 53 \text { ) } \\
\text { [IV cephalosporin or oral floroquinolone] } \\
\text { Ribavirin ( } \mathrm{n}=44 / 53) \\
\text { [2,000 mg stat, then } 1,000-1,200 \mathrm{mg} ; 10-14 \\
\text { days] } \\
\text { IV methylprednisolone + oral prednisolone (if no } \\
\text { improvement on ribavirin; } n=44 / 53 \text { ) } \\
\text { [1 mg/kg q8h for } 5 \text { days, } 1 \mathrm{mg} / \mathrm{kg} \text { q12h for } 5 \text { days; } \\
\text { oral prednisolone tapered over } 11 \text { days] } \\
\text { Pulse methylprednisolone (rescue therapy; } \\
n=24 / 53 \text { ) } \\
\text { [500mg twice daily for } 3 \text { days] }\end{array}$ & Mortality: 5 patients & $\begin{array}{l}\text { Anemia: } 32 \text { out of } 44 \text { patients } \\
\text { receiving ribavirin, onset average } 3 \\
\text { days after initiating treatment; } \\
\text { normalized after discontinuing } \\
\text { ribavirin }\end{array}$ \\
\hline $\begin{array}{l}\text { Liu, } 2005^{24} \\
\text { SARS }\end{array}$ & $\begin{array}{l}\text { Initial antibiotic therapy }(n=36 / 36) \\
\text { macrolide or floroquinolone] } \\
\text { Ribavirin }(n=35 / 36) \\
\text { [loading dose } 2 \mathrm{~g} \text {, followed by } 1-1.2 \mathrm{~g} / \text { day for } 10\end{array}$ & $\begin{array}{l}\text { Mortality: } 2 \text { patients (both developed } \\
\text { ARDS) }\end{array}$ & None reported \\
\hline
\end{tabular}




\section{Uh ST STMTICHAEL'S}

\begin{tabular}{|c|c|c|c|}
\hline $\begin{array}{l}\text { Author, } \\
\text { Year; } \\
\text { Diagnosis }\end{array}$ & $\begin{array}{l}\text { Drug therapy (sample size) } \\
\text { [dose, route of administration, frequency, } \\
\text { duration] }\end{array}$ & Effectiveness Outcomes & Safety Outcomes \\
\hline & $\begin{array}{l}\text { days (median; range, } 3-18 \text { days) within } 0-7 \\
\text { days (median, } 1 \text { day) of hospitalization] } \\
\text { IV Immunoglobulin ( } n=22 / 36 \text { ) } \\
\text { [ } 500 \mathrm{mg} / \mathrm{kg} / \text { day for } 2 \text { days, treatment started a } \\
\text { median of } 6 \text { days (range, } 2-19 \text { days) after, } \\
\text { symptom onset] } \\
\text { IV methylprednisolone ( } n=32 / 36 \text { ) } \\
\text { [2-4 mg/kg/day, treatment started a median of } 4 \\
\text { days (range, } 1-10 \text { days) after symptom onset] }\end{array}$ & & \\
\hline $\begin{array}{l}\text { Muller, } \\
2007^{25 * *} \\
\text { SARS }\end{array}$ & $\begin{array}{l}\text { Ribavirin alone ( } n=90 / 306) \\
{[83 \% \text { of patients received first dose in } 48 \text { hours }} \\
\text { of admission; mean } \pm \text { SD total dose } 23.3 \pm 9.4 \\
\text { g, median treatment duration } \\
7 \text { days (IQR } 5-9 \text { days)] } \\
\text { Ribavirin with corticosteroids ( } n=93 / 306) \\
\text { [NR] } \\
\text { Corticosteroids ( } n=81 / 306) \\
\text { [NR] } \\
\text { No treatment }(n=42 / 306)\end{array}$ & $\begin{array}{l}\text { Mechanical ventilation: } 27 \text { patients } \\
\text { receiving ribavirin, } 19 \text { patients not } \\
\text { receiving ribavirin }(p=0.88) \\
\text { Mortality: } 20 \text { patients receiving ribavirin, } \\
10 \text { patients not receiving ribavirin } \\
(p=0.42)\end{array}$ & $\begin{array}{l}\text { Discontinuation due to adverse } \\
\text { events: } 28 \text { patients [19 anemia or } \\
\text { hemolysis, } 5 \text { hepatitis or } \\
\text { transaminitis, } 1 \text { bradycardia, } 1 \text { atrial } \\
\text { fibrillation, } 1 \text { nausea, } 1 \text { unspecified] } \\
\text { Risk of adverse events associated } \\
\text { with ribavirin (adjusted for steroid } \\
\text { use and infection severity) } \\
\text { [OR (99\% Cl),p-value] } \\
\text { Progressive anemia: } 3.0(1.5-6.1) \text {, } \\
<0.0001 \\
\text { Bradycardia: } 2.3(1.0-5.1), 0.007 \\
\text { Hypomagnesemia: } 21(5.8-73), \\
<0.0001 \\
\text { Hypocalcemia: } 1.8(0.91-3.4), 0.028 \\
\text { Hepatitis, biochemical: } 1.8(0.74- \\
4.6), 0.08\end{array}$ \\
\hline $\begin{array}{l}\text { Alhumaid, } \\
2018^{19} \\
\text { MERS }\end{array}$ & $\begin{array}{l}\text { Oseltamivir }(n=13 / 107) \\
\text { Ribavirin }(n=61 / 107) \\
\text { Lopinavir/ritonavir }(n=41 / 107) \\
\text { Interferon ( } \alpha 1 a, \alpha 2 a \text {, or }(n=54 / 107)\end{array}$ & $\begin{array}{l}\text { ICU Admission: } 53 \text { patients } \\
\text { Confirmed Pneumonia: } 21 \text { patients } \\
\text { Mortality: } 54 \text { patients }\end{array}$ & NR \\
\hline
\end{tabular}




\section{UL ST. MICHAEL'S \\ UNITY HEALTH TORONTO}

\begin{tabular}{|c|c|c|c|}
\hline $\begin{array}{l}\text { Author, } \\
\text { Year; } \\
\text { Diagnosis }\end{array}$ & $\begin{array}{c}\text { Drug therapy (sample size) } \\
\text { [dose, route of administration, frequency, } \\
\text { duration] }\end{array}$ & Effectiveness Outcomes & Safety Outcomes \\
\hline & $\begin{array}{l}\text { Interferon- } \beta 1 a(n=48 / 107) \\
\text { Initial antibacterial therapy }(n=107 / 107) \\
\text { Glucocorticoids }(n=24 / 107) \\
\text { Immunoglobulin therapy }(n=33 / 107) \\
\text { Mycophenolate mofetil }(n=22 / 107) \\
\text { Convalescent Plasma }(n=14 / 107)\end{array}$ & & \\
\hline $\begin{array}{l}\text { Habib, } \\
2019^{22} \\
\text { MERS }\end{array}$ & Ribavirin and Interferon $(n=61 / 63)$ & $\begin{array}{l}\text { Mortality: } 14 \text { patients receiving } \\
\text { combination therapy, } 1 \text { patient not } \\
\text { receiving therapy } \\
\text { Confirmed Pneumonia (on hospital } \\
\text { admission): } 55 \text { patients }\end{array}$ & NR \\
\hline $\begin{array}{l}\text { Khalid, } \\
2016^{23} \\
\text { MERS }\end{array}$ & $\begin{array}{l}\text { Ribavirin and Interferon } \alpha 2 a(n=11 / 11) \\
\text { Ribavirin dose adjusted based on creatinine } \\
\text { clearance, treatment started a median of } 6 \text { days } \\
\text { from symptom onset for a maximum of } 2 \text { weeks }\end{array}$ & Mortality: 9 patients & None reported \\
\hline \multicolumn{4}{|c|}{ Case Reports/Series $n=34$} \\
\hline $\begin{array}{l}\text { Holshue, } \\
2020^{35} \\
\text { COVID-19 }\end{array}$ & $\begin{array}{l}\text { Remdesivir (was started day } 7(\mathrm{n}=1) \text { ) } \\
\text { Vancomycin (1750mg loading dose followed by } \\
1 \mathrm{~g} \text { administered intravenously every } 8 \text { hours) } \\
\text { and cefepime (administered every } 8 \text { hours) } \\
(\mathrm{n}=1) \\
\text { Vancomycin was discontinued the same day } \\
\text { Remdesivir was initiated and cefepime was } \\
\text { discontinued the next day }\end{array}$ & $\begin{array}{l}\text { Patient was still hospitalized at study } \\
\text { end but showing significant } \\
\text { improvement. }\end{array}$ & NR \\
\hline $\begin{array}{l}\text { Wang, } \\
2020 a^{57} \\
\text { COVID-19 }\end{array}$ & $\begin{array}{l}\text { Lopinavir/ritonavir }(\mathrm{n}=4) \\
\text { [lopinavir } 400 \mathrm{mg} / \mathrm{ritonavir} 100 \mathrm{mg}, \mathrm{q} 12 \mathrm{~h} \text {, oral, } \\
\text { duration } 6-15 \text { days] } \\
\text { Additional treatments }(\mathrm{n}=4) \\
\text { Arbidol }[0.2 \mathrm{~g}, 3 \text { times daily, oral] } \\
\text { Shufeng Jiedu Capsule [2.08, three times daily, }\end{array}$ & $\begin{array}{l}\text { At study end two patients were } \\
\text { confirmed COVID-19 negative and } \\
\text { discharged, two patients remained } \\
\text { hospitalized, one still requiring } \\
\text { mechanical ventilation }\end{array}$ & NR \\
\hline
\end{tabular}




\section{UL ST. MICHAEL'S \\ UNITY HEALTH TORONTO}

\begin{tabular}{|c|c|c|c|}
\hline $\begin{array}{l}\text { Author, } \\
\text { Year; } \\
\text { Diagnosis }\end{array}$ & $\begin{array}{c}\text { Drug therapy (sample size) } \\
\text { [dose, route of administration, frequency, } \\
\text { duration] }\end{array}$ & Effectiveness Outcomes & Safety Outcomes \\
\hline & $\begin{array}{l}\text { oral] } \\
\text { antibiotic treatment }[\mathrm{NR}] \\
\text { intravenous immunoglobulin }[\mathrm{NR}]\end{array}$ & & \\
\hline $\begin{array}{l}\text { Wang, } \\
\text { 2020b56 } \\
\text { COVID-19 }\end{array}$ & $\begin{array}{l}\text { Oseltamivir }(n=124) \\
\text { Antibacterial therapy }(n=89) \\
\text { [moxifloxacin, ceftriaxone, azithromycin] } \\
\text { Glucocorticoid therapy }(n=62)[N R]\end{array}$ & $\begin{array}{l}34 \text { patients admitted to ICU, } 17 \text { of which } \\
\text { required invasive mechanical } \\
\text { ventilation. At study end } 47 \text { patients had } \\
\text { been discharged and } 6 \text { patients in ICU } \\
\text { died }\end{array}$ & NR \\
\hline $\begin{array}{l}\text { Avendano, } \\
2003^{28} \\
\text { SARS }\end{array}$ & $\begin{array}{l}\text { Ribavirin }(\mathrm{n}=14) \\
{[\mathrm{IV}, 2 \mathrm{~g} \text { (loading), then } 1 \mathrm{~g} \text { every } 6 \text { hrs for } 4 \text { days, }} \\
\text { then } 0.5 \mathrm{~g} \text { every } 8 \text { hrs for } 3 \text { days] } \\
\text { Levofloxacin }(\mathrm{n}=14) \\
\text { [500 mg daily for } 6 \text { days] } \\
\text { methylprednisolone/prednisone }(\mathrm{n}=5) \\
\text { [125 mg intravenously every } 6 \text { hours) for } 1 \text { to } 2 \\
\text { days, followed by a tapering dose of prednisone } \\
(40 \mathrm{mg})]\end{array}$ & $\begin{array}{l}\text { All patients improved clinically } 15 \text { days } \\
\text { after admission and were eventually } \\
\text { discharged home. }\end{array}$ & $\begin{array}{l}\text { All patients were treated with } \\
\text { ribavirin, and all patients received } \\
\text { levofloxacin. All patients } \\
\text { experienced a drop in hemoglobin. } \\
\text { Nine patients had hemolytic anemia. }\end{array}$ \\
\hline $\begin{array}{l}\text { Cheng, } \\
2004^{31} \\
\text { SARS }\end{array}$ & $\begin{array}{l}\text { Ribavirin }(\mathrm{n}=13) \\
\text { Oral ribavirin at a dose of } 40 \text { to } 60 \mathrm{mg} / \mathrm{kg} \text { per } \\
\text { day. } \\
\text { Oral prednisolone }(0.5 \text { to } 1 \mathrm{mg} / \mathrm{kg} \text { per day) } \\
\text { Intravenous ribavirin }(20 \mathrm{mg} / \mathrm{kg} \text { per day) and } \\
\text { pulse methylprednisolone }(10 \mathrm{mg} / \mathrm{kg} \text { per day for } \\
2 \text { to } 3 \text { days } \\
\text { Cephalosporin, macrolide, prednisone }\end{array}$ & All recovered without sequelae $(n=13)$ & NR \\
\hline $\begin{array}{l}\text { Cheng, } \\
2005^{30} \\
\text { SARS }\end{array}$ & $\begin{array}{l}\text { Ribavirin (oral) } 40 \mathrm{mg} / \mathrm{kg} / \mathrm{d} \text { for } 10 \text { days }(\mathrm{n}=1) \\
\text { Oral prednisolone }(1 \mathrm{mg} / \mathrm{kg} / \mathrm{d} \text { for } 14 \text { days) }\end{array}$ & $\begin{array}{l}\text { Complete resolution according to CT of } \\
\text { the thorax performed } 3 \text { months after the } \\
\text { initial presentation }\end{array}$ & NR \\
\hline
\end{tabular}




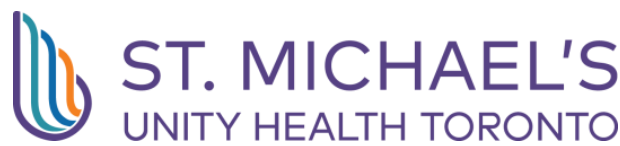

\begin{tabular}{|c|c|c|c|}
\hline $\begin{array}{l}\text { Author, } \\
\text { Year; } \\
\text { Diagnosis }\end{array}$ & $\begin{array}{c}\text { Drug therapy (sample size) } \\
\text { [dose, route of administration, frequency, } \\
\text { duration] }\end{array}$ & Effectiveness Outcomes & Safety Outcomes \\
\hline & $\begin{array}{l}\text { Corticosteroids } \\
\text { Oxygen }\end{array}$ & & \\
\hline $\begin{array}{l}\text { Chiang, } \\
2003^{32} \\
\text { SARS }\end{array}$ & $\begin{array}{l}\text { Ribavirin (oral) 1000mg daily for } 10 \text { days }(n=4) \\
\text { Antibiotic - levofloxacin ( } n=4) \\
\text { Intravenous immunoglobulin (IVIG:I } \\
\text { g/kg/day for } 2 \text { day) after onset of symptoms } \\
(n=4) \\
\text { If severe hypoxia (Pa02 IFi02<200) occurred, } \\
\text { then methylprednisolone + mechanical } \\
\text { ventilation } 2 \text { mg/kg/day were given }(n=1)\end{array}$ & $\begin{array}{l}\text { No mortality case was found in our } \\
\text { study, however, } 1 \text { case complicated with } \\
\text { adult respiratory distress syndrome }\end{array}$ & NR \\
\hline $\begin{array}{l}\text { Gomersall, } \\
2004^{33} \\
\text { SARS }\end{array}$ & $\begin{array}{l}\mathrm{N}=54 \\
\text { Broad-spectrum antibiotics (withdrawn if } \\
\text { bacterial infection could not be confirmed) } \\
\text { Ribavirin } \\
\text { [8 mg/kg every } 8 \mathrm{~h} \text { intravenously for } 7-10 \text { days } \\
\text { followed by } 4 \mathrm{mg} / \mathrm{kg} \text { enterally for another } 11-14 \\
\text { days] } \\
\text { Low-dose corticosteroids } \\
\text { Pulse methylprednisolone (rescue therapy) } \\
\text { [500 mg up to a total of } 3 \mathrm{~g}-5 \mathrm{~g} \text { ] }\end{array}$ & $\begin{array}{l}\text { Study population consisted of } 54 \\
\text { patients with SARS who required } \\
\text { admission to ICU. All were admitted for } \\
\text { respiratory failure } \\
\text { Mortality: } 28 \text { days after ICU admission } \\
34 \text { patients ( } 63 \% \text {; } 95 \% \mathrm{CI} 49.6-74.6) \\
\text { were alive and not mechanically } \\
\text { ventilated. } 6 \text { patients were alive but still } \\
\text { ventilated (11.3\%; } 95 \% \mathrm{Cl} 5.3-22.6) \\
\text { and } 14 \text { died }(25.9 \% \text {; } 16.1-38.9) \text {. }\end{array}$ & NR \\
\hline $\begin{array}{l}\text { Hon } 2003^{36} \\
\text { SARS }\end{array}$ & $\begin{array}{l}\text { Ribavirin (oral; } 40 \mathrm{mg} / \mathrm{kg} \text { daily } 1-2 \text { doses) } \\
\text { If high fever ribavirin was administered through } \\
\text { IV }(20 \mathrm{mg} / \mathrm{kg} \text { daily, } 3 \text { doses })(\mathrm{n}=10) \\
\text { Antibiotics }(\mathrm{n}=10) \\
\text { Corticosteroids - prednisolone }(0.5 \mathrm{mg} / \mathrm{kg} \text { daily }\end{array}$ & $\begin{array}{l}\text { All patients required supplemental } \\
\text { oxygen and two patients were placed } \\
\text { on mechanical ventilation. All patients } \\
\text { were alive at study end. }\end{array}$ & None reported \\
\hline
\end{tabular}




\section{(L) ST. MICHAEL'S}

\begin{tabular}{|c|c|c|c|}
\hline $\begin{array}{l}\text { Author, } \\
\text { Year; } \\
\text { Diagnosis }\end{array}$ & $\begin{array}{c}\text { Drug therapy (sample size) } \\
\text { [dose, route of administration, frequency, } \\
\text { duration] }\end{array}$ & Effectiveness Outcomes & Safety Outcomes \\
\hline & $\begin{array}{l}\text { at } \\
\text { Prince of Wales Hospital, and } 2.0 \mathrm{mg} / \mathrm{kg} \text { daily at } \\
\text { Princess } \\
\text { Margaret Hospital) }(\mathrm{n}=8) \\
\text { Pulsed intravenous methylprednisolone (10- } \\
20 \mathrm{mg} / \mathrm{kg})(\mathrm{n}=1)\end{array}$ & & \\
\hline $\begin{array}{l}\text { Knowles, } \\
2003^{39} \\
\text { SARS }\end{array}$ & $\begin{array}{l}\text { Ribavirin }(n=110) \\
\text { All patients received concurrent antibiotics after } \\
\text { the initial assessment, and } 50 \% \text { received } \\
\text { corticosteroids at some point during the course } \\
\text { of their illness }\end{array}$ & NR & $\begin{array}{l}\text { Hemolytic anemia: } 67 \text { patients, } \\
\text { treated with transfusion of } 1 \mathrm{U} \text { of } \\
\text { packed RBCs } \\
\text { Hypomagnesemia: } 35 \text { patients } \\
\text { Hypocalcemia: } 36 \text { patients }\end{array}$ \\
\hline $\begin{array}{l}\text { Kwan, } \\
2004^{40} \\
\text { SARS }\end{array}$ & $\begin{array}{l}\text { Ribavirin ( } \mathrm{n}=12) \\
\text { Dose of ribavirin was half of that in patients with } \\
\text { normal renal function; Corticosteroids (oral } \\
\text { prednisolone, intravenous methylprednisolone, } \\
\text { hydrocortisone). } \\
\text { The average cumulative dose of hydrocortisone } \\
\text { or equivalent in the dialysis group was } 11.1 \mathrm{~g} \\
\text { (range, } 2.5 \text { to } 41.1 \mathrm{~g} \text { ), which was similar to the } \\
\text { control } \\
\text { group (average, } 17.8 \mathrm{~g} \text {; range, } 3.0 \text { to } 31.2 \mathrm{~g} \text { ). } \\
2 \text { patients received convalescence plasma, } 1 \\
\text { received intravenous immunoglobulin, and one } \\
\text { received pentaglobulin }\end{array}$ & $\begin{array}{l}\text { ICU admission }(n=4) \\
\text { Mortality }(n=0)\end{array}$ & 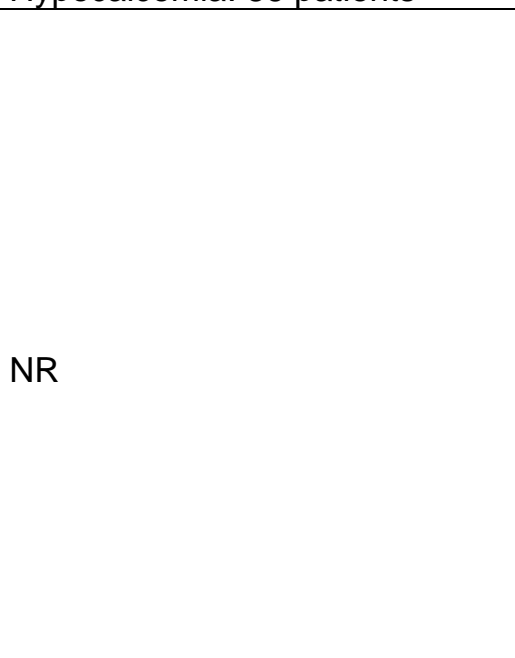 \\
\hline $\begin{array}{l}\text { Lam, } 2004^{41} \\
\text { SARS }\end{array}$ & $\begin{array}{l}\text { Ribavirin (oral; } 2,400 \mathrm{mg} / \text { day for } 10 \text { days) was } \\
\text { commenced on day } 14(\mathrm{n}=1)\end{array}$ & $\begin{array}{l}\text { The patient was successfully } \\
\text { discharged on Day 28, after altogether }\end{array}$ & NR \\
\hline
\end{tabular}




\section{(1) ST MICHAEL'S}

\begin{tabular}{|c|c|c|c|}
\hline $\begin{array}{l}\text { Author, } \\
\text { Year; } \\
\text { Diagnosis }\end{array}$ & $\begin{array}{l}\text { Drug therapy (sample size) } \\
\text { [dose, route of administration, frequency, } \\
\text { duration] }\end{array}$ & Effectiveness Outcomes & Safety Outcomes \\
\hline & $\begin{array}{l}\text { Prednisolone (oral; } 1 \mathrm{mg} / \mathrm{kg} \text { for } 10 \text { days; was } \\
\text { reduced to } 20 \mathrm{mg} / \text { day on day } 21 \text { ) commenced on } \\
\text { day } 14(\mathrm{n}=1) \\
\text { Antibiotics - cefepime ( } 1 \mathrm{~g} \text { three times a day), } \\
\text { imipenem and cilastatin ( } 500 \mathrm{mg} \text { four times a day } \\
\text { on Day } 6 \text { of admission) ( } n=1) \\
\\
\text { Clarithromycin ( } 500 \mathrm{mg} \text { twice a day was added to } \\
\text { her treatment on day } 9 \text { due to mild bilateral } \\
\text { infiltration in lower zones found in her chest } \\
\text { radiograph) }(n=1)\end{array}$ & $\begin{array}{l}10 \text { days of prednisolone and ribavirin } \\
\text { treatment. }\end{array}$ & \\
\hline $\begin{array}{l}\text { Lau, } 2004^{42} \\
\text { SARS }\end{array}$ & $\begin{array}{l}\text { Ribavirin ( } \mathrm{n}=71 \text { ) } \\
\text { Ribavirin was given for } 10-14 \text { days as per } \\
\text { protocol at } 400 \mathrm{mg} \text { every } 8 \mathrm{~h} \text { ( } 1200 \mathrm{mg} \text { daily) } \\
\text { intravenously for at least } 3 \text { days (or until } \\
\text { stabilization), then } 1200 \mathrm{mg} \text { twice daily ( } 2400 \\
\text { mg daily) orally; } \\
\text { Antibiotics (levofloxacin or amoxicillin-clavulanic } \\
\text { acid+clarithromycin), corticosteroids } \\
\text { (methylprednisone+prednisolone), pulsed } \\
\text { steroids (methylprednisone), } \\
\text { Additional pulsed methylprednisolone } 500 \mathrm{mg} \\
\text { twice daily intravenously for } 2 \text { days (total } 2 \mathrm{~g} \text { ), }\end{array}$ & $\begin{array}{l}\text { ICU }(n=15 / 7) \\
\text { Mortality }(n=3) \\
\text { Major sepsis due to ventilator } \\
\text { associated pneumonia (MRSA) with } \\
\text { acute respiratory distress syndrome } \\
(n=1)\end{array}$ & $\begin{array}{l}\text { Hyperglycemia }(n=71) \\
\text { Pnuemomediastinum/thoraces } \\
(n=71) \\
\text { Acute confusion }(n=71) \\
\text { Anxiety/depression }(n=71)\end{array}$ \\
\hline $\begin{array}{l}\text { Lopez, } \\
2004^{44} \\
\text { SARS }\end{array}$ & $\begin{array}{l}\text { Ribavirin }(I V)(n=4) \\
\text { Corticosteroids }(n=4) \\
\text { Intubation }+ \text { mechanical pressure controlled } \\
\text { ventilation }(n=4)\end{array}$ & $\begin{array}{l}\text { ICU admission: } 4 \text { patients transferred to } \\
\text { ICU } \\
\text { Mortality: One patient died within } 15 \\
\text { days of hospitalization }\end{array}$ & NR \\
\hline
\end{tabular}




\section{UL ST. MICHAEL'S \\ UNITY HEALTH TORONTO}

\begin{tabular}{|c|c|c|c|}
\hline $\begin{array}{l}\text { Author, } \\
\text { Year; } \\
\text { Diagnosis }\end{array}$ & $\begin{array}{c}\text { Drug therapy (sample size) } \\
\text { [dose, route of administration, frequency, } \\
\text { duration] }\end{array}$ & Effectiveness Outcomes & Safety Outcomes \\
\hline $\begin{array}{l}\text { Poutanen, } \\
2003^{47} \\
\text { SARS }\end{array}$ & $\begin{array}{l}\text { Oseltamivir (oral) + ribavirin (IV; } 2 \text { g (loading), } \\
\text { then } 1 \mathrm{~g} \text { every } 6 \text { hours for } 4 \text { days, then } 500 \mathrm{mg} \\
\text { every } 8 \text { hours for } 4-6 \text { days) ( } n=7) \\
\text { Antibiotics }(n=10) \\
\text { Mechanical ventilation }(n=5)\end{array}$ & $\begin{array}{l}\text { ICU admission: } 5 \text { patients transferred to } \\
\text { the ICU } \\
\text { Mortality: } 3 \text { patients; all deaths occurred } \\
\text { in patients who had an underlying } \\
\text { immune-compromised state }\end{array}$ & NR \\
\hline $\begin{array}{l}\text { So, } 2003^{49} \\
\text { SARS }\end{array}$ & $\begin{array}{l}\text { Ribavirin (IV) and ribavirin (orally) ( } \mathrm{n}=31 \text { ) } \\
\text { Ribavirin (IV) } 400 \mathrm{mg} \text { every } 8 \mathrm{~h} \text { ( } 1200 \mathrm{mg} \text { daily) } \\
\text { for at least } 3 \text { days (or until condition becomes } \\
\text { stable), then ribavirin (orally) } 1200 \mathrm{mg} \text { twice } \\
\text { daily ( } 2400 \mathrm{mg} \text { daily); } \\
\text { Antibiotics (31), corticosteroids (31), pulsed } \\
\text { methylprednisolone (13), ventilation (4) }\end{array}$ & Death $(n=31)$ & None reported \\
\hline $\begin{array}{l}\text { Sung, } \\
2004^{51} \\
\text { SARS }\end{array}$ & $\begin{array}{l}\text { Ribavirin ( } \mathrm{n}=138 \text { ) } \\
\text { Combination of ribavirin and "low dose" } \\
\text { corticosteroid therapy on day } 3-4 \text { (oral ribavirin } \\
\text { as a loading dose of } 2.4 \mathrm{~g} \text { stat followed by } 1.2 \mathrm{~g} \\
\text { three times daily); } \\
\text { Antibiotics (cefotaxime, levofloxacin, } \\
\text { clarithromycin), oseltamivir, prednisolone, } \\
\text { hydrocortisone, pulse methylprednisone, } \\
\text { intravenous cefotaxime } 1 \mathrm{~g} \text { every } 6 \text { hours with } \\
\text { either oral levofloxacin } 500 \text { mg daily or } \\
\text { clarithromycin } 500 \text { mg twice daily, prednisolone } \\
0.5-1 \mathrm{mg} / \mathrm{kg} \text { body weight per day), }\end{array}$ & $\begin{array}{l}\text { ICU }(n=37) \\
\text { Mortality }(n=15) \\
6 \text { patients died after failing to respond to } \\
\text { ribavirin+low dose treatment } \\
2 \text { died after failing to respond to initial } \\
\text { pulse methylprednisone } \\
7 \text { died after failing to respond to further } \\
\text { pulse methylprednisone }\end{array}$ & $\begin{array}{l}\text { Hyperglycemia (plasma spot } \\
\text { glucose }>11 \mathrm{mmol} / \mathrm{L})(\mathrm{n}=107) \\
\text { Hypokalaemia (plasma potassium < } \\
3.0 \mathrm{mmol} / \mathrm{L})(\mathrm{n}=107) \\
\text { Transient confusion, delusion, or } \\
\text { anxiety ( } \mathrm{n}=107) \\
\text { Hemolytic anemia (bilirubin increase } \\
>20 \text { micromol/L or reticulocyte count } \\
>1 \%)(\mathrm{n}=138)\end{array}$ \\
\hline $\begin{array}{l}\text { Tang, } 2003^{52} \\
\text { SARS }\end{array}$ & $\begin{array}{l}\text { Ribavirin (IV;6.5 to } 10 \mathrm{mg} / \mathrm{kg} \text { daily) }(\mathrm{n}=2) \\
\text { Antibiotics - levofloxacin }(\mathrm{n}=2)\end{array}$ & Mortality: One patient died & NR \\
\hline
\end{tabular}




\section{(1) ST MICHAEL'S}

\begin{tabular}{|c|c|c|c|}
\hline $\begin{array}{l}\text { Author, } \\
\text { Year; } \\
\text { Diagnosis }\end{array}$ & $\begin{array}{l}\text { Drug therapy (sample size) } \\
\text { [dose, route of administration, frequency, } \\
\text { duration] }\end{array}$ & Effectiveness Outcomes & Safety Outcomes \\
\hline & $\begin{array}{l}\text { Imipenem (changed from ribavirin on day } 21) \\
(n=1) \\
\text { Corticosteroid - pulsed methylprednisolone }(0.5 \mathrm{~g} \\
\text { daily was given from day } 7 \text { to } 9 \text {, then } 1 \mathrm{~g} \text { daily on } \\
\text { days } 10,12 \text {, and } 13)(n=1)\end{array}$ & & \\
\hline $\begin{array}{l}\text { Tiwari, } \\
2003^{53} \\
\text { SARS }\end{array}$ & $\begin{array}{l}\text { Ribavirin ( } \mathrm{n}=36 \text { ) } \\
\text { Ribavirin - } 8 \mathrm{mg} / \mathrm{kg} \text { tid (intravenous), } 1.2 \mathrm{~g} \text { tid } \\
\text { (oral); corticosteroid, combination of cefepime } \\
\text { and clarithromycin }\end{array}$ & $\begin{array}{l}\text { ICU }(n=2) \\
\text { Mortality }(n=1)\end{array}$ & NR \\
\hline $\begin{array}{l}\text { Tsang, } \\
2003^{54} \\
\text { SARS }\end{array}$ & $\begin{array}{l}\text { Ribavirin (IV) or ribavirin (oral) }(\mathrm{n}=10) \\
\text { Ribavirin (IV) } 8 \mathrm{mg} / \mathrm{kg} \text { every } 8 \mathrm{hrs} \text { OR ribavirin } \\
\text { (oral) } 1.2 \mathrm{~g} \text { every } 8 \mathrm{hrs}(1 \text { patient); corticosteroids } \\
\text { (10), oxygen (2), mechanical ventilation (2) }\end{array}$ & Death $(n=10)$ & NR \\
\hline $\begin{array}{l}\text { Tsui, } 2003^{55} \\
\text { SARS }\end{array}$ & $\begin{array}{l}\text { Ribavirin ( } \mathrm{n}=323 \text { ) } \\
\text { Loading dose of } 33 \mathrm{mg} / \mathrm{kg} \text { of ribavirin, followed } \\
\text { by } 20 \mathrm{mg} / \mathrm{kg} \text { every } 8 \mathrm{~h} \text {, was given intravenously; } \\
\text { Antibiotic (levofloxacin or amoxicillin/clavulinate } \\
\text { acid, clarithromycin, hydrocortisone or } \\
\text { prednisone, methylprednisolone), } \\
\text { Hydrocortisone, } 2 \mathrm{mg} / \mathrm{kg} \text { every } 6 \mathrm{~h} \text { or } 4 \mathrm{mg} / \mathrm{kg} \\
\text { every } 8 \mathrm{~h} \text {, together with } \\
\text { ribavirin. } \\
\text { The total duration of therapy could range from } \\
14 \text { to } 21 \text { days. } \\
\text { Pulsed doses of methylprednisolone (500 mg } \\
\text { per dose) }\end{array}$ & $\begin{array}{l}\text { Hospital admission ( } n=323) \\
\text { ICU }(n=67) \\
\text { Mortality }(n=26) \\
\text { Crude mortality rate of our cohort after } \\
47 \pm 8 \text { days of follow-up was } 7.9 \%(95 \% \\
C l, 5 \% \text { to } 10.8 \%)\end{array}$ & NR \\
\hline
\end{tabular}




\section{(1) ST. MICHAEL'S}

\begin{tabular}{|c|c|c|c|}
\hline $\begin{array}{l}\text { Author, } \\
\text { Year; } \\
\text { Diagnosis }\end{array}$ & $\begin{array}{c}\text { Drug therapy (sample size) } \\
\text { [dose, route of administration, frequency, } \\
\text { duration] }\end{array}$ & Effectiveness Outcomes & Safety Outcomes \\
\hline & $\begin{array}{l}\text { Ribavirin plus steroid therapy was administered } \\
1.2 \pm 1.7 \text { days after admission. }\end{array}$ & & \\
\hline $\begin{array}{l}\text { Wu, } 2003^{59} \\
\text { SARS }\end{array}$ & $\begin{array}{l}\text { Ribavirin/oseltamivir, }(\mathrm{n}=31 / 58) \\
\text { [duration: } 5.7 \text { (3.2 days)] } \\
\text { Ribavirin (IV) } 4-8 \mathrm{mg} / \mathrm{kg} \text { tid, } 4 \\
\text { Tetracyclines, aminoglycosides, quinolones, } \\
\text { macrolides, glycopeptides, cephalosporins, } \\
\text { methylprednisolone, human gamma-globulin; } \\
\text { Mean dose ranged from } 67.3 \text { (28.2) mg/day to } \\
82.4 \text { (30.5) mg/d over } 4.9 \text { (2.4) days; } \\
\text { Human gamma-globulin infused intravenously } \\
\text { (n=66) at mean daily dose of } 26.4 \text { (16.1) mg/day } \\
\text { over } 3.7 \text { (1.8) days } \\
\text { Interferon-alpha ( } \mathrm{n}=45 \text { ) over } 5.1 \text { (1.9) days }\end{array}$ & Mechanical ventilation $(n=1)$ & NR \\
\hline $\begin{array}{l}\text { Wong, } \\
2003^{58} \\
\text { SARS }\end{array}$ & $\begin{array}{l}\text { Ribavirin ( } \mathrm{n}=4) \\
\text { Two patients received } 4 \mathrm{mg} / \mathrm{kg} \text { ribavirin thrice } \\
\text { daily while the other } 2 \text { patients received } 8 \mathrm{mg} / \mathrm{kg} \\
\text { ribavirin thrice daily; } \\
\text { Antibiotics ( } \mathrm{n}=4 \text { ) } \\
\text { Patients } 3 \text { and } 4 \text { also received a higher daily } \\
\text { dose of corticosteroids ( } 4 \mathrm{mg} / \mathrm{kg} \text { hydrocortisone } \\
\text { every } 4 \text { hours or } 15 \mathrm{mg} / \mathrm{kg} \text { methylprednisolone } \\
\text { daily) compared with patients } 1 \text { and } 2 \text { ( } 4 \mathrm{mg} / \mathrm{kg} \\
\text { hydrocortisone every } 6 \text { hours). }\end{array}$ & Mortality $(n=4)$ & None reported \\
\hline Al-Tawfiq, & Ribavirin $(\mathrm{n}=5)$ & All patients had severe disease with & NR \\
\hline
\end{tabular}




\section{1) STMCHAEL'S}

\begin{tabular}{|c|c|c|c|}
\hline $\begin{array}{l}\text { Author, } \\
\text { Year; } \\
\text { Diagnosis }\end{array}$ & $\begin{array}{c}\text { Drug therapy (sample size) } \\
\text { [dose, route of administration, frequency, } \\
\text { duration] }\end{array}$ & Effectiveness Outcomes & Safety Outcomes \\
\hline $\begin{array}{l}2013^{27} \\
\text { MERS }\end{array}$ & $\begin{array}{l}\text { Median number of days from admission to } \\
\text { therapy with ribavirin and interferon was } 19 \\
\text { (range 10-22) } \\
\text { Interferon and corticosteroids } \\
\text { All patients received adjunctive corticosteroid } \\
\text { therapy }\end{array}$ & $\begin{array}{l}\text { progressive respiratory failure, } \\
\text { developed multi-organ failure, and died } \\
\text { a mean } 39.6 \text { (standard deviation } 8.5 \text { ) } \\
\text { days after admission }\end{array}$ & \\
\hline $\begin{array}{l}\text { Al-Tawfiq, } \\
2018^{26} \\
\text { MERS }\end{array}$ & $\begin{array}{l}\text { Ribavirin }(n=2) \\
\text { Interferon- } \alpha 2 b(n=2)\end{array}$ & $\begin{array}{l}\text { Mortality: "Two of the three cases in the } \\
\text { present report were treated with } \\
\text { interferon- } \alpha 2 b \text { and ribavirin and all } \\
\text { patients recovered. The timing of the } \\
\text { initiation of anti-viral agents seems to } \\
\text { be an important determinant of the } \\
\text { response to therapy. " }\end{array}$ & NR \\
\hline $\begin{array}{l}\text { Habib, } \\
2015^{34} \\
\text { MERS }\end{array}$ & $\begin{array}{l}\text { Oseltamivir ( } n=1) \\
\text { Antibiotics and Low-molecular-weight heparin } \\
(\mathrm{n}=1) \\
\text { Interferon and Ribavirin were added }(\mathrm{n}=1) \\
\text { Steroid injection for fetal lung maturity }(\mathrm{n}=1) \\
\text { Patient was initially started on antibiotics and } \\
\text { LMWH, however, became worse after standard } \\
\text { antimicrobial therapy. Started on Oseltamivir, } \\
\text { received steroid injections for fetal lung maturity } \\
\text { and growth. Interferon and Ribavirin were added } \\
\text { to on mechanical ventilation }\end{array}$ & $\begin{array}{l}\text { ICU/Critical Care }(n=1) \text { : "the woman's } \\
\text { condition became worse despite } \\
\text { standard antimicrobial therapy and she } \\
\text { had to be transferred to the ICU for } \\
\text { assisted respiration" } \\
\text { Mortality }(n=1) \text { : "on day } 8 \text { the woman } \\
\text { deteriorated with h/o MERS-CoV } \\
\text { pneumonia, respiratory failure - septic } \\
\text { shock; The woman deceased after } \\
\text { failed resuscitation. }\end{array}$ & NR \\
\hline $\begin{array}{l}\text { Khalid, } \\
2015^{37} \\
\text { MERS }\end{array}$ & $\begin{array}{l}\text { Ribavirin }(n=14) \\
\text { All patients received } 1 \mathrm{mg} / \mathrm{kg} \text { of }\end{array}$ & $\begin{array}{l}\text { ICU admission+intubation }(n=14) \\
\text { Death }(n=9)\end{array}$ & NR \\
\hline
\end{tabular}




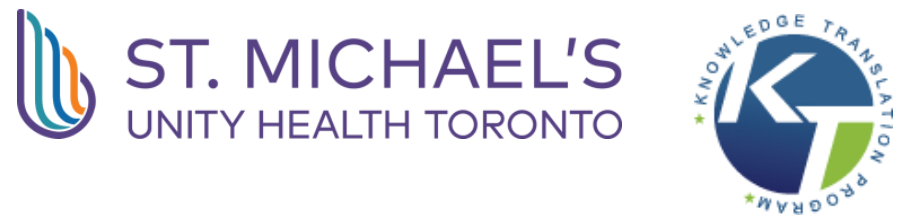

\begin{tabular}{|c|c|c|c|}
\hline $\begin{array}{l}\text { Author, } \\
\text { Year; } \\
\text { Diagnosis }\end{array}$ & $\begin{array}{c}\text { Drug therapy (sample size) } \\
\text { [dose, route of administration, frequency, } \\
\text { duration] }\end{array}$ & Effectiveness Outcomes & Safety Outcomes \\
\hline & $\begin{array}{l}\text { methylprednisolone continuous infusion for } \\
\text { ARDS. } \\
11 \text { patients received combination of ribavirin and } \\
\text { peginterferon alpha-2a; interferon alpha-2a, } \\
\text { methylprednisolone }\end{array}$ & & \\
\hline $\begin{array}{l}\text { Kim, } 2016^{38} \\
\text { MERS }\end{array}$ & $\begin{array}{l}\text { Ribavirin (oral; } 2,000 \text { mg loading, then } 1,200 \mathrm{mg} \\
\text { three times/day) } \\
\text { AND } \\
\text { lopinavir/ritonavir ( } 400 / 100 \mathrm{mg} \text { two times/day) } \\
(\mathrm{n}=1)\end{array}$ & NR & $\begin{array}{l}\text { Hemolytic anemia and } \\
\text { thrombocytopenia, onset occurred } \\
\text { on day } 5 \text { of treatment } \\
\text { Ribavirin and lopinavir/ritonavir were } \\
\text { stopped after } 5 \text { days } \\
\text { of treatment } \\
\text { because it was suspected that the } \\
\text { hemolytic anemia and } \\
\text { thrombocytopenia was an adverse } \\
\text { drug reaction. } \\
\text { Lasted } 9 \text { days and was discharged } \\
\text { in } 14 \text { days }\end{array}$ \\
\hline $\begin{array}{l}\text { Lee, } 2017^{43} \\
\text { MERS }\end{array}$ & $\begin{array}{l}\text { Oseltamivir + ribavirin (oral; } 2000 \mathrm{mg} \text { (loading), } \\
\text { then } 600 \mathrm{mg} \text { every } 8 \text { hours for } 3 \text { days, then } 400 \\
\text { mg every } 8 \text { hours for } 4 \text { days) }(n=1) \\
\text { Interferon- } \alpha 2 b \text { ( } 180 \text { mcg once commencing on } \\
\text { day } 9)(n=1) \\
\text { Antibiotics }(n=1) \\
\text { Oxygen }(1 \mathrm{~L} / \mathrm{min}, 2 \mathrm{~L} / \mathrm{min} \text { on day } 9,5 \mathrm{~L} / \mathrm{min} \text { on day } \\
\text { 10) }(n=1) \\
\text { Ventilation on day } 12(n=1)\end{array}$ & 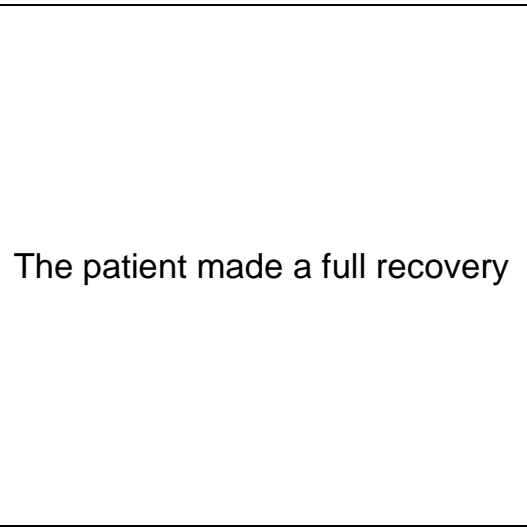 & $\begin{array}{l}\text { Transient progression of } \\
\text { thrombocytopenia from D12 } \\
\text { appeared to be caused by interferon } \\
\text { and ribavirin }\end{array}$ \\
\hline
\end{tabular}




\section{UL ST. MICHAEL'S \\ UNITY HEALTH TORONTO}

\begin{tabular}{|c|c|c|c|}
\hline $\begin{array}{l}\text { Author, } \\
\text { Year; } \\
\text { Diagnosis }\end{array}$ & $\begin{array}{c}\text { Drug therapy (sample size) } \\
\text { [dose, route of administration, frequency, } \\
\text { duration] }\end{array}$ & Effectiveness Outcomes & Safety Outcomes \\
\hline $\begin{array}{l}\text { Motabi, } \\
2016^{45} \\
\text { MERS }\end{array}$ & $\begin{array}{l}\text { Oseltamivir }(n=4) \\
\text { Antimicrobials and antibiotics (vancomycin, } \\
\text { voriconazole) }\end{array}$ & $\begin{array}{l}\text { ICU admission }(n=1) \\
\text { Mortality }(n=2) \\
\text { Severe pneumonia }(n=4)\end{array}$ & NR \\
\hline $\begin{array}{l}\text { Shalhoub, } \\
2014^{48} \\
\text { MERS }\end{array}$ & $\begin{array}{l}\text { Ribavirin (a loading dose of } 2 \text { gm., followed by } \\
600 \text { mg orally every } 12 \text { hours) }(n=1) \\
\text { Interferon alpha } 2 a \text { (180cg subcutaneously once } \\
\text { weekly) }(n=1) \\
\text { interferon beta }(n=1) \\
\text { Antiretroviral treatment that consisted of a } \\
\text { combination of tenofovir/emtricitabine } \\
\text { (TDF/FTC) }(300 / 200 \text { mg orally once daily) in } \\
\text { combination with ritonavir boosted atazanavir } \\
\text { (atazanvir } 300 \mathrm{mg} \text { in addition to ritonavir } 100 \mathrm{mg}) \\
\text { orally daily }(n=1)\end{array}$ & $\begin{array}{l}\text { Patient was released } 38 \text { days after } \\
\text { being hospitalized on the mentioned } \\
\text { antiretroviral treatment in addition to } \\
\text { prophylactic } \\
\text { trimethoprim/sulfamethoxazole } 960 \mathrm{mg} \\
\text { daily }\end{array}$ & NR \\
\hline $\begin{array}{l}\text { Spanakis, } \\
2014^{50} \\
\text { MERS }\end{array}$ & $\begin{array}{l}\text { Ribavirin }(n=1) \\
\text { [2000 mg loading dose, followed } \\
\text { by } 1200 \text { mg p.o. every } 8 \text { h for } 8 \text { days] } \\
\text { Lopinavir/ritonavir ( } 400 / 100 \text { mg twice daily) }(n=1) \\
\text { Pegylated interferon ( } 180 \mathrm{~g} \text { subcutaneously once } \\
\text { per week for } 12 \text { days) }(n=1)\end{array}$ & $\begin{array}{l}\text { ICU admission: One patient was } \\
\text { intubated, ventilated and transferred to } \\
\text { a negative pressure room in the ICU of } \\
\text { the same hospital } \\
\text { Mortality: "During the course of his } \\
\text { hospitalization, the patient was } \\
\text { diagnosed with adenocarcinoma of the } \\
\text { colon and eventually died from septic } \\
\text { shock } 2 \text { months and } 19 \text { days after the } \\
\text { initial diagnosis." }\end{array}$ & $\begin{array}{l}\text { Jaundice and hyperbilirubinemia, } \\
\text { time of onset is unclear, ribavirin } \\
\text { was discontinued on day } 20\end{array}$ \\
\hline $\begin{array}{l}\text { Bogdanov, } \\
2017^{29} \\
\text { Other } \\
\text { coronavirus }\end{array}$ & $\begin{array}{l}\text { Foscarnet }(n=1) \\
\text { Intravenous immunoglobulins }(n=1)\end{array}$ & $\begin{array}{l}\text { Mortality }(n=1) \text { : "the patient died due to } \\
\text { respiratory paralysis" }\end{array}$ & NR \\
\hline
\end{tabular}




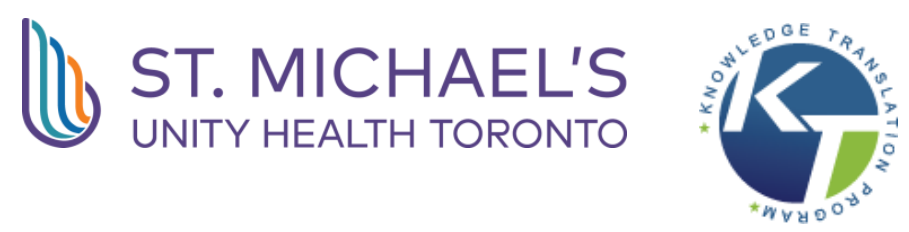

\begin{tabular}{|c|c|c|c|}
\hline $\begin{array}{l}\text { Author, } \\
\text { Year; } \\
\text { Diagnosis }\end{array}$ & $\begin{array}{c}\text { Drug therapy (sample size) } \\
\text { [dose, route of administration, frequency, } \\
\text { duration] }\end{array}$ & Effectiveness Outcomes & Safety Outcomes \\
\hline $\begin{array}{l}\text { Oger, } 2017^{46} \\
\text { Other } \\
\text { coronavirus }\end{array}$ & $\begin{array}{l}\text { Ribavirin }(n=1) \\
\text { Patients who received oral ribavirin for non-HCV } \\
\text { infections; dose was } 400 \mathrm{mg} \text { tid or } 200 \mathrm{mg} \text { tid if } \\
\text { there was renal insufficiency }\end{array}$ & Mortality $(n=0)$ & NR \\
\hline
\end{tabular}




\section{DS ST.MMCHAELS}

\section{APPENDIX 5-Quality Appraisal/Risk of Bias - Complete Results}

\begin{tabular}{|c|c|c|c|c|c|c|c|}
\hline \multicolumn{8}{|c|}{ Cochrane Risk of Bias Tool - Randomized Controlled Trials } \\
\hline First author & $\begin{array}{c}\text { Random } \\
\text { sequence } \\
\text { generation }\end{array}$ & $\begin{array}{c}\text { Allocation } \\
\text { concealment }\end{array}$ & $\begin{array}{c}\text { Blinding of } \\
\text { participants } \\
\text { and personnel }\end{array}$ & $\begin{array}{l}\text { Blinding of } \\
\text { outcome } \\
\text { assessment }\end{array}$ & $\begin{array}{l}\text { Incomplete } \\
\text { outcome data }\end{array}$ & $\begin{array}{l}\text { Selective } \\
\text { reporting }\end{array}$ & Other bias \\
\hline Lee, $2004^{6}$ & Unclear risk & Unclear risk & Unclear risk & Low risk & Low risk & Unclear risk & Low risk \\
\hline Park, 20197 & Unclear risk & Unclear risk & Low risk & Low risk & Low risk & Unclear risk & Low risk \\
\hline Zhao, $2003^{8}$ & High risk & High risk & High risk & Unclear risk & Low risk & Unclear risk & Low risk \\
\hline
\end{tabular}

\begin{tabular}{|c|c|c|c|c|c|c|c|c|}
\hline \multicolumn{9}{|c|}{ Newcastle Ottawa Scale - Cohort studies } \\
\hline $\begin{array}{l}\text { Author, } \\
\text { Year }\end{array}$ & $\begin{array}{l}\text { Representative- } \\
\text { ness of the } \\
\text { exposed cohort }\end{array}$ & $\begin{array}{c}\text { Selection of the } \\
\text { non-exposed } \\
\text { cohort }\end{array}$ & $\begin{array}{l}\text { Ascertainment } \\
\text { of exposure }\end{array}$ & $\begin{array}{l}\text { Demonstration } \\
\text { that outcome } \\
\text { was not present } \\
\text { at start }\end{array}$ & $\begin{array}{l}\text { Comparability of } \\
\text { cohorts (design } \\
\text { or analysis) }\end{array}$ & $\begin{array}{l}\text { Assessment of } \\
\text { outcome }\end{array}$ & $\begin{array}{l}\text { Was follow-up } \\
\text { long enough for } \\
\text { outcomes to } \\
\text { occur }\end{array}$ & $\begin{array}{c}\text { Adequacy of } \\
\text { follow up of } \\
\text { cohorts }\end{array}$ \\
\hline $\begin{array}{l}\text { Alkhadhairi, } \\
2018^{9}\end{array}$ & $\begin{array}{l}\mathrm{B} \text { - somewhat } \\
\text { representative }\end{array}$ & $\begin{array}{l}\text { A - same } \\
\text { community }\end{array}$ & $\begin{array}{l}\text { A - secure } \\
\text { record }\end{array}$ & B - no & $\begin{array}{c}\text { D - no } \\
\text { description }\end{array}$ & $\begin{array}{c}\text { A - } \\
\text { independent } \\
\text { or blind }\end{array}$ & $A$ - yes & A - complete \\
\hline $\begin{array}{l}\text { Arabi, } \\
2019^{10}\end{array}$ & $\begin{array}{c}\text { A - truly } \\
\text { representative }\end{array}$ & $\begin{array}{l}\text { A - same } \\
\text { community }\end{array}$ & $\begin{array}{l}\text { A - secure } \\
\text { record }\end{array}$ & B - no & $\begin{array}{l}\text { A - age and } \\
\text { other factor }\end{array}$ & $\begin{array}{l}\text { A - } \\
\text { independent } \\
\text { or blind }\end{array}$ & A - yes & A - complete \\
\hline $\begin{array}{l}\text { Chan, } \\
2003^{11}\end{array}$ & $\begin{array}{l}\text { B - somewhat } \\
\text { representative }\end{array}$ & $\begin{array}{l}\text { A - same } \\
\text { community }\end{array}$ & $\begin{array}{l}\text { A - secure } \\
\text { record }\end{array}$ & B - no & $\begin{array}{l}\text { A - age and } \\
\text { other factor }\end{array}$ & $\begin{array}{l}\text { A - } \\
\text { independent } \\
\text { or blind }\end{array}$ & A - yes & $\begin{array}{c}\text { B - small } \\
\text { number lost }\end{array}$ \\
\hline Choi, $2016^{12}$ & $\begin{array}{l}\text { B - somewhat } \\
\text { representative }\end{array}$ & $\begin{array}{l}\text { A - same } \\
\text { community }\end{array}$ & $\begin{array}{l}\text { A - secure } \\
\text { record }\end{array}$ & B - no & $\begin{array}{c}\text { D - no } \\
\text { description }\end{array}$ & $\begin{array}{l}\text { A - } \\
\text { independent } \\
\text { or blind }\end{array}$ & A - yes & A - complete \\
\hline Chu, $2004^{13}$ & $\begin{array}{l}B \text { - somewhat } \\
\text { representative }\end{array}$ & $\begin{array}{l}\text { A - same } \\
\text { community }\end{array}$ & $\begin{array}{l}\text { A - secure } \\
\text { record }\end{array}$ & B - no & $\begin{array}{l}\text { A - age and } \\
\text { other factor }\end{array}$ & $\begin{array}{l}\text { A - } \\
\text { independent } \\
\text { or blind }\end{array}$ & A - yes & A - complete \\
\hline Guo, $2019^{14}$ & $\begin{array}{l}\mathrm{B} \text { - somewhat } \\
\text { representative }\end{array}$ & $\begin{array}{l}\text { A - same } \\
\text { community }\end{array}$ & $\begin{array}{l}\text { A - secure } \\
\text { record }\end{array}$ & A - yes & $\begin{array}{c}\text { D - no } \\
\text { description }\end{array}$ & $\begin{array}{l}\text { A - } \\
\text { independent } \\
\text { or blind }\end{array}$ & A - yes & $\begin{array}{c}\text { B - small } \\
\text { number lost }\end{array}$ \\
\hline
\end{tabular}




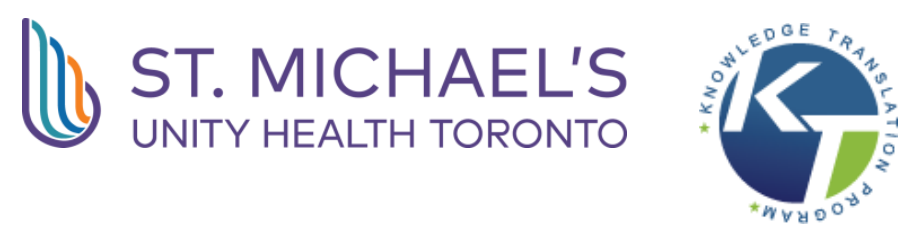

\begin{tabular}{|c|c|c|c|c|c|c|c|c|}
\hline Ho, $2003^{15}$ & $\begin{array}{l}\text { B - somewhat } \\
\text { representative }\end{array}$ & $\begin{array}{l}\text { A - same } \\
\text { community }\end{array}$ & $\begin{array}{l}\text { A - secure } \\
\text { record }\end{array}$ & A - yes & $\begin{array}{c}\text { D - no } \\
\text { description }\end{array}$ & $\begin{array}{c}\text { A - } \\
\text { independent } \\
\text { or blind }\end{array}$ & A - yes & A - complete \\
\hline Lau, $2009^{16}$ & $\begin{array}{c}\text { A - truly } \\
\text { representative }\end{array}$ & $\begin{array}{l}\text { A - same } \\
\text { community }\end{array}$ & $\begin{array}{l}\text { A - secure } \\
\text { record }\end{array}$ & B - no & $\begin{array}{l}\text { A - age and } \\
\text { other factor }\end{array}$ & $\begin{array}{c}\text { A - } \\
\text { independent } \\
\text { or blind }\end{array}$ & unclear & $\begin{array}{c}\text { D - no } \\
\text { description }\end{array}$ \\
\hline $\begin{array}{l}\text { Leong, } \\
2004^{17}\end{array}$ & $\begin{array}{l}\text { B - somewhat } \\
\text { representative }\end{array}$ & $\begin{array}{c}\text { A - same } \\
\text { community }\end{array}$ & $\begin{array}{l}\text { A - secure } \\
\text { record }\end{array}$ & B - no & $\begin{array}{l}\text { A - age and } \\
\text { other factor }\end{array}$ & $\begin{array}{c}\text { A - } \\
\text { independent } \\
\text { or blind }\end{array}$ & A - yes & A - complete \\
\hline $\mathrm{Li}, 2006^{18}$ & $\begin{array}{l}\mathrm{B} \text { - somewhat } \\
\text { representative }\end{array}$ & $\begin{array}{l}\text { A - same } \\
\text { community }\end{array}$ & $\begin{array}{l}\text { A - secure } \\
\text { record }\end{array}$ & B - no & $\begin{array}{l}\text { A - age and } \\
\text { other factor }\end{array}$ & $\begin{array}{l}\text { A - } \\
\text { independent } \\
\text { or blind }\end{array}$ & A - yes & $\begin{array}{c}\text { B - small } \\
\text { number lost }\end{array}$ \\
\hline
\end{tabular}

